\author{
UNIVERSIDADE DE SÃO PAULO \\ FACULDADE DE FILOSOFIA, LETRAS E CIÊNCIAS HUMANAS \\ DEPARTAMENTO DE LETRAS ORIENTAIS \\ PROGRAMA DE LITERATURA E CULTURA RUSSA
}

LUCIANO AUGUSTO MEYER

\title{
Esquizofrenia Pós-Soviética:
}

Sonhos, Vazio e Identidade em A Metralhadora de Argila Versão corrigida 
LUCIANO AUGUSTO MEYER

\title{
Esquizofrenia Pós-Soviética:
}

Sonhos, Vazio e Identidade em A Metralhadora de Argila

Versão corrigida

\begin{abstract}
Dissertação apresentada ao programa de pós-graduação em Literatura e Cultura Russa do Departamento de Letras Orientais da Faculdade de Filosofia, Letras e Ciências Humanas da Universidade de São Paulo, como requisito para obtenção de título de Mestre em Literatura e Cultura Russa. Pesquisa desenvolvida com bolsa da Coordenação de Aperfeiçoamento de Pessoal de Nível Superior (Capes).
\end{abstract}

Orientador: Prof. Dr. Bruno Barretto Gomide

De acordo, 


\section{AGRADECIMENTOS}

Em primeiro lugar, gostaria de agradecer ao meu orientador, Bruno Barretto Gomide, que me convidou para realizar este trabalho em duas oportunidades: tanto quando era apenas um trabalho de graduação, quanto ao me incluir em uma vaga que acabara de ficar disponível. Também foi ele que me ofereceu a bolsa de estudos assim que foi possível, acreditando no meu trabalho com dedicação integral.

Em seguida, devo agradecer à Coordenação de Aperfeiçoamento de Pessoal de Nível Superior (CAPES) por disponibilizar a bolsa que permitiu que eu me dedicasse exclusivamente à escrita desta dissertação.

A todos os amigos e colegas que acompanharam esta produção, de longe ou de perto, seja com correções, traduções, elogios, apoio ou críticas à minha demora para escrevê-la inteira, pois essa presença é mais do que importante para desenvolver um trabalho como esse.

À minha família, pelo apoio e incentivo aos estudos. Aos meus pais, sobretudo, por ouvirem várias teorias e relações que eu me empolgava para inserir na dissertação, as quais também geraram inúmeras discussões filosóficas e espirituais.

À minha namorada, Mariana, por todo o apoio emocional em diversas (muitas mesmo) ocasiões de desespero, depressão e, evidentemente, empolgação com este trabalho. Sem ela, caminhar pelas dificuldades seria ainda mais complicado, e nada disto seria possível.

\section{Cпасuбo!}


"Somos nosso próprio refúgio.

Quem melhor poderia sê-lo?

Com nosso ser bem controlado, refúgio raro encontraremos."

Estrofe 4, capítulo XII (“Nós próprios”) do Darmapada 
Resumo: Notadamente um dos escritores russos mais bem-sucedidos na década de 1990, Victor Pelevin se caracteriza por uma obra pouco convencional no que concerne à construção de personagens e mundos em que elas habitam. A transição política e cultural ocorrida após a queda do governo soviético, em 1991, é um dos fatores que influenciam as obras de grande parte dos autores pós-modernos na Rússia; entretanto, o sucesso de Pelevin se deve também às peculiaridades de sua escrita que, em vez de apenas promover críticas à sociedade que o precedeu, também inclui reflexões filosóficas e metafísicas - por vezes consideradas pretensiosas demais pela crítica - que abordam essa transição. Em $A$ metralhadora de argila, romance de 1996, o autor remonta as batalhas da Guerra Civil Russa, em 1919, colocando-as como um mundo paralelo a uma instituição psiquiátrica em 1991. O interesse, então, é estudar o processo de recriação que Pelevin faz da realidade "pré-soviética" e como ele a compara ao período pós-soviético, apontando aspectos no romance que identifiquem a noção de identidade e a mudança a que este conceito está sujeito após as transformações sociais nesses períodos da história recente da Rússia.

Palavras-chave: Victor Pelevin; A metralhadora de argila; ficção russa; literatura russa pósmoderna; pós-soviético.

\begin{abstract}
One of the most renowned Russian writers of the 1990s, Viktor Pelevin distinguishes himself for the construction of characters and worlds in which they inhabit. The political and cultural transition after the end of the Soviet government, in 1991, is one of the factors that have an effect on most of the literary works from Post-Modern authors in Russia; although, Pelevin's success as well is due to singularities in his writing, which instead of only criticise the Soviet society before him, also includes philosophical and metaphysical thoughts - sometimes viewed as too pretentious by the critics - that discuss the transition. In The clay machine-gun, a 1996 novel, Pelevin remembers the battles of the Russian Civil War, in 1919, putting them as a parallel world within a madhouse in 1991. So, the interest in this study is to understand Pelevin's recreation of the Pre-Soviet reality and how he compares it to the PostSoviet period, highlighting elements on the novel that trace the notion of identity and the adjustment it takes after the social transformation in these both recent Russian times.
\end{abstract}

Keywords: Viktor Pelevin; The clay machine-gun; Russian fiction; Post-Modern Russian literature; Post-Soviet.

Contato: lucianoaugustomeyer@hotmail.com 


\section{SUMÁRIO}

1. INTRODUÇÃO

7

2. CULTURA DA CISÃO: A RÚSSIA E SUAS DIVISÕES HISTÓRICAS

2.1 Panorama histórico: "velhas" e "novas" maneiras, da religião à dualidade cultural 13

2.2 Reformas petrinas e a ocidentalização da Rússia 18

2.3 Ocidentalistas versus Eslavófilos e a constituição de uma identidade cindida 20

3. PELEVIN E O PÓS-MODERNISMO RUSSO

3.1 O "hiper" de Epstein e a fragmentação da realidade 30

3.2 Pelevin e a possibilidade de (re)construção da realidade 35

4. A METRALHADORA DE ARGILA: SONHOS E IDENTIDADE 40

4.1 Maria ocidentalista

4.2 Serdiuk e a identificação com o Oriente 54

4.3 Volodin: metafísica da identidade 72

4.4 Piotr como síntese da cisão 91

4.4.1 Tchapaiev e Vazio - primeiro encontro 108

4.4.2 Na casa de banho 113

4.4.3 Identidade na cera: Barão Jungern 118 


\section{INTRODUÇÃO}

A presente dissertação é fruto de um interesse pessoal pela cultura russa desde o primeiro contato com a obra de Dostoievski, em 2009. Desde então comecei a ler diversos autores de diferentes épocas da história do país eslavo, e, dentre eles, me deparei com Victor Pelevin - a princípio, em O Elmo do Horror, edição coincidentemente traduzida pelo meu orientador, que li em 2011. Posteriormente, li também A Vida dos Insetos, romance construído em pequenas histórias paralelas, em 2012, tentando entender melhor o funcionamento da escrita e da ficção de Pelevin.

No entanto, foi só em 2013 que adquiri a edição brasileira de $A$ metralhadora de argila $^{1}$, livro escrito em 1996 que me instigou pela profundidade com que aborda a questão da loucura na sociedade russa de 1991, ou seja, logo após a queda dos soviéticos. Ademais, como já citado, Dostoievski foi meu primeiro contato com a literatura do país; durante a leitura de Crime e Castigo, fui absolutamente influenciado psicologicamente, chegando a ter insônia no processo. A metralhadora de argila, por sua vez, teve efeitos muito semelhantes, acompanhando aquele que, em 2009, se tornou o romance que mais aprecio - e, portanto, tornando-se um dos romances que mais passei a apreciar. $O$ estilo de Pelevin promove um aprofundamento sobretudo pelas referências, às vezes implícitas, a esquemas filosóficos e metafísicos da existência, como se formassem uma forma de "teste" ao leitor para que se desloque da verossimilhança das situações apresentadas para um universo completamente volátil e desconhecido, e isso certamente foi o fator

1 Apesar de existir uma versão em português do romance, para esta pesquisa utilizarei a versão em inglês, de 1999, intitulada The Clay Machine-gun, traduzida do russo por Andrew Bromfield. 
principal para que me interessasse por um estudo mais minucioso.

À época da leitura do romance de Pelevin, minha graduação já havia tomado outros rumos além da habilitação em língua russa, mas segui cursando algumas disciplinas oferecidas pelo curso. No ano de 2013, por sua vez, atendi à disciplina Cultura Russa, ministrada pelo meu hoje orientador, Bruno Barretto Gomide. O tema principal do curso, no segundo semestre, foi a divisão da Rússia entre a vertente eslavófila e a ocidentalista, e como se deu essa "batalha" ideológica, além de suas evidências na cultura do país.

Enquanto lia $A$ metralhadora de argila, percebi que ali estava mais uma divisão do mundo russo: entre o mundo "pré-soviético" - da Guerra Civil - e o mundo pós-soviético - em 1991. Da mesma maneira, parecia se repetir um embate entre uma realidade russa (uma revolução que mudaria o papel do país no contexto mundial) e a "abertura" da Rússia ao mundo ocidental (com o mercado financeiro e a economia voltando a se relacionar com os países de fora do Bloco Socialista).

Entretanto, foi em um trabalho de graduação para uma disciplina da Escola de Comunicação e Artes-ECA/USP que tive oportunidade de me aprofundar mais na leitura do romance. Utilizando-me do conteúdo de Cultura Russa, desenvolvi uma monografia sobre os efeitos da ocidentalização da Rússia, após a construção de São Petersburgo, na memória psicológica da identidade do Homem russo. Para isso, precisei também entrevistar meu hoje orientador, que, então, disse conhecer Pelevin, tê-lo traduzido (O Elmo do Horror), e ter interesse na pesquisa que desenvolvi sobre o autor.

Então, quando terminei a graduação, em 2014, já havia uma ideia de pesquisa sobre um autor muito pouco conhecido no Brasil, embora extremamente 
popular na Rússia. A ideia, a priori, era trabalhar com o que Pelevin traz da cisão histórica russa para o final do século $X X$, identificando elementos em seu romance que corroborem a visão de que ainda há essa cisão no país.

Por outro lado, Pelevin é muitas vezes criticado por enveredar em discussões metafísicas e filosóficas nos seus romances, deixando de lado aspectos mais "palpáveis" como política e sociologia. Talvez por isso ainda seja um autor desconsiderado pela crítica literária de nosso país - embora no Ocidente haja algumas pesquisas a seu respeito, sobretudo nos EUA e na Inglaterra, onde boa parte da obra está traduzida para o inglês.

O fato de ser uma dissertação pioneira no Brasil sobre Victor Pelevin tem como positivo a possibilidade de ter contato maior com a obra, mas também proporcionar, num cenário de sucesso, uma maior abrangência do mercado à tradução desse autor russo. Além disso, é interessante também poder apresentar uma visão diferente, oriunda de um brasileiro, sobre esse autor russo.

Em contrapartida, o pioneirismo é acompanhado de incertezas e dificuldade para encontrar material em português. Em inglês, poucas pesquisas realmente se aprofundam na obra de Pelevin, geralmente tratando de seus livros em geral, e não de um romance específico. Ao estudá-lo, minha ambição é dar uma atenção maior a uma obra específica do autor, buscando uma análise que se aprofunde mais nos conceitos e pretensões de $A$ metralhadora de argila do que apenas identificando este romance no conjunto da obra. A esperança é de, também, auxiliar nas leituras vindouras de quem se interessar pelo autor, sobretudo com embasamento em uma pesquisa em português, de nosso país, e de um leitor que admira o trabalho de Pelevin. 
Apesar de pouco comentado e traduzido no Brasil, Victor Olegovitch Pelevin (1962-) é um dos escritores mais bem-sucedidos no cenário literário da Rússia póssoviética. A dificuldade, no entanto, é ter contato com o autor e poder traçar um perfil consistente de quem está por trás dos romances escritos. Isso se evidencia quando se considera que

\begin{abstract}
Sua [de Pelevin] reputação de recluso desmente uma percepção comum da imagem autoral, a qual ele trabalha cuidadosamente. O escritor que "nunca dá entrevistas" é constantemente citado, e cada citação contradiz veementemente a outra, de maneira a dar ao Pelevin biográfico uma aura de mistério e complexidade, adequando-o a uma figura cult do final do século XX. Como resultado, há mais desinformação do que informação sobre a biografia de Pelevin. Na medida em que ele tem uma imagem pública, esta é a de um místico recluso. (MCCAUSLAND: 2003, p. 209)²
\end{abstract}

O material que concerne à vida de Pelevin é escasso, sobretudo fora da

Rússia. Apesar de ser objeto de estudos dentro do próprio país, a figura de um escritor que se recusa a fazer parte dessa "classe" literária - evitando contatos públicos para comentar a própria obra, por exemplo - permite que a névoa que paira sobre o autor se transponha à obra. Apesar de ter estudado no Instituto Literário Gorky, que ensinava os ditames artísticos segundo o Realismo Socialista, a convivência de Pelevin com outros autores foi rara - estando entre eles Victor Erofeev e Vladimir Sorokin, conhecidos como os criadores do Pós-Modernismo literário russo.

2 No original em inglês: "His reputation for reclusiveness belies a keen sense of the authorial image, which he is careful to maintain and manage. The writer who 'never gives interviews' is constantly quoted, and the quotes sharply contradict each other in such a way as to give the biographical Pelevin an aura of mystery and complexity befitting a cult figure of the outgoing twentieth century. As a result, there is more misinformation than information regarding Pelevin's biography. Inasmuch as he has a public persona, it is that of a mystic recluse."

Para os textos em inglês, todas as traduções contidas nesta dissertação serão de autoria própria. 
Se pouco se sabe sobre a biografia de Pelevin, por outro lado há uma facilidade de acesso às suas obras: sob aprovação do próprio autor, todos os seus livros publicados até 2000 estão disponíveis para leitura no website www.pelevin.nov.ru, mostrando não só uma maior abertura a diversos públicos, mas também predisposição do autor à adaptação da própria literatura aos novos formatos de divulgação. Esse "aceno" em favor da Internet, somado ao conteúdo não-realista e período de escrita, permite que incluamos Pelevin no movimento Pós-Moderno russo.

Um dos aspectos que mais impressionam na atualidade de $A$ metralhadora de argila, enquanto parte de um Pós-Modernismo global, é a abordagem à esquizofrenia em sintonia com sonhos e o irreal. Um dos filmes de maior sucesso cult dos anos 90 é Clube da Luta (1999) - baseado no livro homônimo, de 1996, mesmo ano de lançamento de Metralhadora -, que trata do problema de identidade no mundo estadunidense; em 2010 foi lançado o filme A Origem, cuja premissa se baseia na invasão de sonhos, com momentos de "arquitetura de realidades"; em 2016 estreou a série Westworld, na qual androides começam a tomar consciência de si mesmos e de diferentes realidades enquanto são atrações de um complexo para entretenimento das elites. É relevante citar a procedência estadunidense dessas produções, evidenciando que, mesmo após quase um século inteiro de rivalidades culturais inclusive -, EUA e Rússia compartilham a problemática da identidade e da consciência de uma realidade. 
Esses exemplos mostram que o romance de Pelevin não só concerne à identidade russa, mas também participa de uma preocupação comum a diversas produções - literárias e cinematográficas - em outros países. Nele, a esquizofrenia também é temporal, com a lembrança de 1919, período da Guerra Civil Russa, em contraposição a 1991, ano da queda do governo soviético. A busca pela identidade do protagonista se dá pelos sonhos compartilhados, a partir dos quais nos deparamos com diferentes questões do novo reconhecimento próprio russo, imprescindíveis para que esse mesmo protagonista tome consciência de quem ele é.

O que há de pós-moderno em $A$ metralhadora de argila é semelhante àquilo a que temos acesso em outros lugares e em outras mídias, fazendo dele um romance que pode atrair não só os que leem os russos, mas também aqueles que se interessam por esse conteúdo que permeia nossa arte atual. Portanto, nesta dissertação proponho que leiamos Pelevin como uma das vozes que, a partir da constituição do histórico de seu país, aborda temas que afetam a vida humana contemporânea. 


\section{CULTURA DA CISÃO: A RÚSSIA E SUAS DIVISÕES HISTÓRICAS}

\section{Panorama histórico: "velhas" e "novas" maneiras, da religião à dualidade cultural}

Antes de colocarmos o romance de Pelevin sob análise, é importante ressaltar que a esquizofrenia presente em sua obra não é apenas fruto da imaginação de um autor interessado em falar da cisão de uma personagem. A Rússia não é apenas curiosa por estar do outro lado do planeta em relação ao Brasil, mas também porque teve sua cultura intrinsecamente influenciada por embates ideológicos que permearam a arte durante séculos.

Não é à toa que Yuri Lotman (1922-1993), historiador cultural e um dos mais notáveis eslavistas do século XX, e Boris Uspensky (1937-), filólogo e semioticista russo, iniciam seu livro A Semiótica da Cultura Russa com um capítulo denominado "O papel dos modelos duplos na dinâmica da cultura russa (até o final do século XVIII)". Logo de início percebemos que a dualidade é, para Lotman e Uspensky, um aspecto básico da formação cultural de seu país. Apesar de o recorte cronológico escolhido não atingir o embate que pretendemos utilizar para analisar $A$ metralhadora de argila - entre eslavófilos e ocidentalistas, oficializado no século XIX -, é importante notar que há, na história da Rússia, um precedente cultural de dualidade.

Lotman e Uspensky propõem, então, que

Uma das oposições mais persistentes que contribui para a estrutura da cultura russa durante toda sua história, da introdução do Cristianismo na Rússia até as reformas de Pedro I é a oposição "velhas" maneiras [starina] $\leftrightarrow$ "novas" maneiras [novizna]. Ela se mostra tão vigorosa e significante que do ponto de vista subjetivo de um portador da cultura, em várias etapas ele 
a absorve para si ou subordina a si outras oposições mais importantes, do tipo: "Rússia $\leftrightarrow$ o Ocidente," "Cristianismo $\leftrightarrow$ paganismo," "fé verdadeira $\leftrightarrow$ fé falsa," "conhecimento ↔ ignorância," [...] (LOTMAN, USPENSKY: 1984, p. 5$)^{3}$

Levando em consideração que essa dualidade, então, está na formação do povo russo, podemos também discutir a identidade acarretada. A fragmentação gerada por uma cultura historicamente cindida, ou então que trafega entre embates, nos permite traçar uma identidade nacional? Essa cisão, então, seria parte inseparável da identidade russa?

Segundo Lotman e Uspensky, o percurso histórico da Rússia transita entre o "novo" e o "velho", de maneira que o cristianismo foi uma novidade no século X; em contrapartida, a civilização oriunda da adoção dessa religião resultou também em uma relação de dependência de Bizâncio: a cultura bizantina, por séculos, foi o alicerce para a formação cultural russa, sobretudo pela exportação da ortodoxia. Por outro lado, no século $\mathrm{XV}$ a relação entre Rússia e bizantinos entra em crise, sobretudo pela iminência da tomada de Constantinopla pelos otomanos.

Moscou, que surgia como nova força por seu papel na batalha pela libertação da Rússia em relação aos mongóis (cujo domínio se estendeu do século XIII ao XV), passava a ter uma importância na região, tanto cultural quanto militarmente. Entre 1438 e 1448, por fim, a Rússia se tornou administrativamente independente de Bizâncio, representando uma quebra com cinco séculos de relação cultural e de dependência. Quando ocorre a tomada de Constantinopla pelos otomanos, em 1453, Moscou já era independente, erguendo-se como a grande capital da Ortodoxia

3 No original em inglês: "One of the most persistent oppositions contributing to the structure of Russian culture throughout its whole history from the introduction of Christianity into Russia until the reforms of Peter I is the opposition 'old' ways [starina] $\leftrightarrow$ 'new' ways [novizna]. It proves to be so vigorous and significant that from the subjective standpoint of a bearer of the culture at various stages it absorbs into itself or subordinates to itself other most important oppositions of the type: 'Russia $\leftrightarrow$ the West,' 'Christianity $\leftrightarrow$ paganism,' 'true faith $\leftrightarrow$ false faith,' 'knowledge $\leftrightarrow$ ignorance,' $[\ldots] "$ 
cristã.

Se a independência do cristianismo russo foi o que iniciou a independência de Moscou, surge então uma pretensão russa: a de se tornar uma "nova Bizâncio" (ou, per se, uma Terceira Roma). A reconstrução de Moscou como capital do Império Russo - e como capital ortodoxa - se deu pelo embate entre o cristianismo latino (ocidental, e, de acordo com os russos, mais preocupado com a aparência) e o ortodoxo russo (preocupado com a essência e a espiritualidade). Dessa maneira, a dualidade que se instalou com a ascensão moscovita foi, sobretudo, nesse embate entre os diferentes cristianismos.

O aparecimento de um novo centro religioso para o cristianismo ortodoxo, por sua vez, fez com que Moscou surgisse como a "salvaguarda de poder espiritual", contrapondo-se ao cristianismo "latino". No entanto, a visão de que os moscovitas representavam uma "Terceira Roma" residia na construção de três embates: 1) a primeira Roma versus os tártaros; 2) Bizâncio como capital cultural cristã; e, por fim, 3) Moscou versus os "ocidentais". Portanto, vemos aqui que a questão cultural e religiosa, que pautou grande parte da identidade moscovita a partir do século $X V$, é exatamente uma das duplas que Lotman e Uspensky reconhecem na subjetividade russa.

Dessa maneira, a Igreja se instala no poder na Rússia, infiltrando-se na identidade do país e estabelecendo-se enquanto identitária com a independência moscovita. A partir daí, por exemplo, surge, pelas mãos do monge Silvestre, o Domostroi, manual de condutas sociais que estabelece parâmetros de comportamento ao povo russo, que deve obediência a Deus, ao czar e à Igreja. Essa burocratização do poder espiritual, junto ao empoderamento de Ivan IV, que 
consolida o território russo até os Urais, simboliza uma extrema centralização do poder - tanto religioso quanto político.

Por sua vez, Ivan IV foi o último herdeiro da dinastia dos Riúrikda, descendentes de uma figura mística escandinava que teria sido a primeira a ter um poder central na Rússia. Ivan assassinou o próprio filho, único herdeiro, mais tarde acarretando o que ficou conhecido como "Tempos Turbulentos" (1598-1613), em que se lutava pelo poder sobre o Estado russo. A reorganização da Rússia só se deu após a escolha da casa dos Románov, que precisaria reconstruir o país.

E se Ivan IV simbolizou tanto poder quanto religiosidade, também estabeleceu uma desconfiança em relação ao Ocidente, consequentemente reiterando a dualidade que Lotman e Uspensky nos apresentaram. Além disso, foi só após a desorganização de seu final de reinado que surgiu uma nova divisão russa: na ortodoxia, havia contrariedades à burocratização do poder espiritual: um exemplo é o arcipreste Avvakum, que pregava, no século XVII, um retorno à "ordem natural", em contraposição à "ordem social". Isso ia de encontro às reformas propostas por Nikon, em 1652, que pretendiam equalizar as práticas religiosas das ortodoxias russa e grega.

Avvakum, que via as reformas de Nikon como "ocidentais", ou "latinas", propunha que as "velhas maneiras" ressurgissem para a Igreja da Rússia, gerando mais uma evidente cisão na cultura russa: o Raskol (que, em russo, significa cisma), oficialmente datada em 1667. Não por coincidência, os partidários do arcipreste eram chamados de Old Believers ("crentes no antigo/velho", em tradução livre), repetindo o termo que Lotman e Uspensky utilizaram em "old ways", ou "velhas maneiras". 
Considerando que estamos citando o século XVII, essa cisão religiosa é contemporânea do lluminismo europeu, e por conseguinte também tem valor para estabelecer o lado dos russos. Se a preocupação era com a configuração religiosa futura do país, a Oeste havia um profundo questionamento à Igreja e seus dogmas. Portanto, a Moscou de Avvakum defendia-se como portadora do poder espiritual e da essência, em contraposição à defesa da razão (e das "aparências", na visão dos russos ortodoxos) na França, por exemplo.

Enquanto os "Tempos Turbulentos" foram base da cisma religiosa, influenciaram também na reestruturação econômica da Rússia, pois, em 1647, já sob a dinastia Románov, foi divulgado um conjunto de leis que organizou um modo de produção sob trabalho compulsório - justificando-se que só dessa forma o país seria reconstruído - transformando os camponeses em servos. A abertura da Europa em relação às condições trabalhistas, com abolição da escravidão em busca de estabelecer novos mercados de consumo, aproxima os russos do modelo que dominou simultaneamente as Américas, onde se fortalecia o regime escravocrata.

Vemos aqui que a formação de uma "Terceira Roma" em Moscou, enquanto detentora do verdadeiro cristianismo (ortodoxo) e do valor espiritual essencial, também colaborou para que a Rússia corroborasse o mesmo embate proposto por Lotman e Uspensky: "velhas maneiras" versus "novas maneiras". Somando-se a isso a servidão estabelecida simultaneamente ao questionamento à escravidão na Europa, a "Terceira Roma" se distanciava dos ocidentais religiosa e produtivamente, de maneira que o século XVII foi o em que essas "maneiras" ficaram mais demarcadas - pelo menos até a ascensão de Pedro I. 


\section{Reformas petrinas e a ocidentalização da Rússia}

Dentre os diversos embates que formam a história cultural russa, o mais evidente e delimitado historicamente - e, no caso desta pesquisa, o mais importante - foi o subsequente à construção de São Petersburgo, no século XVIII, por Pedro I (da dinastia dos Románov). A tentativa de aproximar a Rússia da Europa, cultural e até geograficamente, teve como efeito uma nova questão de identificação do povo russo.

De início, já podemos citar a aproximação espacial: São Petersburgo fica a pouco mais de $700 \mathrm{~km}$ de distância de Moscou, a Noroeste, aproximando-se do Norte da Europa, quase na fronteira com a Finlândia. O mar Báltico, a Oeste, criou a necessidade de se construir uma marinha - algo inovador em um país que, historicamente, se caracterizava por rios, sobretudo por se encontrar em uma massa continental gigantesca.

Desta feita, Pedro I, em sua ânsia de "europeizar" a Rússia, foi o primeiro monarca a viajar à Europa ocidental, rumando à Inglaterra (grande potência do século XVII, especialmente naval) para aprender sobre a produção de barcos e navios. Vemos aqui que figuras náuticas começam a ser introduzidas no país, em uma evidente transformação não só do espaço russo, mas da transformação da relação com ele pelo poder estatal.

A partir da fundação de São Petersburgo, a nova capital russa, notam-se mudanças evidentes que promoviam uma aproximação com a Europa. As conhecidas Reformas Petrinas se deram a partir da construção dessa cidade, e se notabilizaram em diversos âmbitos: 
1. Militar, com a criação de uma marinha e o estabelecimento de regimentos em que se poderia fazer carreira;

2. Religioso, com a fundação do Santo Sínodo e a Igreja passando a responder ao Estado e sendo submetida ao regime burocrático;

3. Imperial, sobretudo com a utilização do termo Imperator por Pedro I, aproximando-se do "Ocidente latino", e com a ocidentalização dos nomes de czares (Pedro em vez de Piotr, Catarina em vez de Ekaterina...);

4. Educacional, após a construção de museus e da Academia de Ciências, acompanhada pela da Universidade de São Petersburgo, em 1724

5. Administrativo, ao se estabelecer uma tabela de níveis hierárquicos, regulando os graus do funcionalismo público russo (inspirada no modelo dinamarquês).

Se essas reformas mudaram a Rússia, afetaram intensamente a nobreza do país, que também faria parte dessa tabela hierárquica: dotada de 14 níveis, ela promovia um trabalho compulsório para o Estado, de maneira a obrigar toda a população a contribuir para a construção do novo projeto de país. Por outro lado, também permitia que, ao atingir o oitavo nível da tabela, se adquirisse um título de nobreza - mesmo que individual e não hereditário, essa mobilidade era algo inédito para o nobre russo.

Se essa tabela instalou na Rússia uma nova regra social embasada na burocracia e na hierarquia, ela também representou uma possibilidade de mobilidade social (pelo menos teoricamente) em um país que antes se caracterizava pelo 
ambiente servil e agrário, representado pelo período moscovita. Os graus eram formais e estamentais, mas a possibilidade aberta permitiu a discussão sobre o indivíduo e o papel dele na construção da nova sociedade russa.

A questão da identidade nacional russa passa muito pelo embate entre Moscou e São Petersburgo, principalmente porque são dois modelos distintos de estabelecimento social e político. A quebra com o modelo bizantino no século $\mathrm{XV}$, a crise dos "Tempos Turbulentos" no final do século XVI, o cisma religioso no século XVII, o afastamento em relação às condições trabalhistas da Europa e a construção, no século XVIII, de uma nova capital para reaproximar a relação cultural com os vizinhos - todos esses momentos históricos são constitutivos de uma identidade fragmentada durante quatro séculos.

Pedro I procurava ocidentalizar a Rússia, que por sua vez é um país cujo território está $80 \%$ na Ásia, mas cuja população se concentra ( $80 \%$ também) na Europa. Sem o apreço estabelecido no século XVIII pelo modelo europeu de comportamento e cultural, não seria possível "oficializar" a dúvida em relação ao que é ser europeu e o que é ser russo. A identidade parece estar em processo de desconstrução, enquanto é transformada pelos embates que constituem a história russa.

\section{Ocidentalistas versus Eslavófilos e a constituição de uma identidade cindida}

Vimos que uma das oposições mais evidentes, segundo Lotman e Uspensky, é entre a Rússia e o Ocidente, e que essa dualidade fundamental participa da subjetividade russa. Aparentemente é a partir dela que, no século XIX, surgirá o 
embate entre Ocidentalistas e Eslavófilos, dois grupos intelectuais que promoveram visões conflitantes sobre a identidade do povo russo.

Consequentemente à fundação de São Petersburgo, em 1703, sabe-se que a Rússia iniciou uma aproximação em direção à Europa, adotando políticas que "copiavam" militarmente a Inglaterra; burocraticamente a Dinamarca; e socialmente a França, sobretudo nos novos costumes da corte - e, indiretamente, na figura de Napoleão, maior exemplo de mobilidade social após a tabela de graus estabelecida por Pedro I. No entanto, a adoção dessas políticas foi feita sobre os alicerces de um autoritarismo que se observava desde os tempos de Ivan IV e do início da dinastia Románov (com o estabelecimento da servidão como modelo de produção para reconstrução do país).

Não à toa, tanto o projeto de Petersburgo quanto a retomada após os "Tempos Turbulentos" significaram uma reestruturação social, mas em ambos a população foi submetida a trabalhos compulsórios e perdas humanas irreparáveis. Lotman e Toporov, em seu "Texto de Petersburgo", associam a construção da cidade a três mitos fundadores: o seu aparecimento súbito no litoral, em contraposição à continentalidade de Moscou; o "custo humano" para sua construção, representando uma "modernização autoritária"; e a ideia de uma vingança da natureza (região pantanosa, sujeita a inundações e transformando a natureza original russa madeira e rios, Moscou - em pedra e água, de Petersburgo).

Com isso, podemos perceber que a "modernização" proposta por Pedro I não foi unanimemente aceita pela Rússia, pois apesar de se contrapor a uma situação de servidão e isolamento, foi baseada no mesmo autoritarismo antecedente. Por exemplo, as revoltas populares lideradas por Pugatchóv, iniciadas em 1773, que 
pretendiam destronar Catarina II, a qual tentou estabelecer um governo liberal que se aproximava de filósofos alemães e franceses - e, no entanto, estabeleceu uma visibilidade maior para os insatisfeitos, os quais reivindicavam poder.

Pugatchóv representava uma revolução popular, que incluía servos, cossacos, minorias étnicas e prisioneiros, por exemplo, e fui a última revolta em grande escala até 1905, já às vésperas da Revolução Russa. Por outro lado, não só a população de estamentos mais "baixos" estava insatisfeita: a inteligentsia, que representava uma fração da nobreza russa, via o projeto petrino como um processo de "fachada", que escondia uma "Rússia verdadeira", não identificada com as propostas ocidentalizantes.

Lotman e Uspensky, por sua vez, reconhecem que

[...] a nova cultura (pós-Petrina) é consideravelmente mais tradicional do que geralmente considerada. Essa nova cultura não é tão construída com modelos "Ocidentais" (apesar de esse ser o sentimento subjetivo), mas com um modelo estrutural inverso ao da cultura antiga. Foi precisamente aqui que se deu uma separação evidente entre a camada cultural mais superficial e mutável e as formas mais profundas, as quais posteriormente se mostraram mais visivelmente na nova hipóstase da consciência. (LOTMAN, USPENSKY: 1984, p.19) ${ }^{4}$

Ou seja, a consciência russa construída pelas reformas petrinas era apenas uma superfície simplificadora da amplitude de possibilidades de interpretação da realidade russa. Não à toa, as revoltas populares se somaram à inteligentsia para questionar uma ocidentalização que só se deu sobre antigos aspectos da cultura do país - segundo vimos, incluindo formas de autoritarismo e imposição de trabalho compulsório, o qual já se enfraquecia no modelo europeu.

Dessa maneira, a superficialidade da ocidentalização, segundo a inteligentsia,

4 Em inglês no original: "[...] the new (post-Petrine) culture is considerably more traditional than is generally thought. This new culture is not so much constructed on "Western" models (although that was indeed the subjective feeling) as on an "inverted" structural model of the old culture. It was precisely here that a manifest separation of the more superficial and changeable cultural layer from all the deep forms took place, and these forms showed forth all the more clearly in the new hypostases of consciousness." 
era um reflexo da artificialidade de São Petersburgo, uma forma de impor e importar modelos europeus deturpados pela alta nobreza. Tanto é que não atingiu o cerne do povo russo, que se rebelou - tanto popularmente quanto na própria nobreza - após perceber que o Ocidente não foi posto em prática, mas adaptado à Rússia, deixando de lado aspectos que significariam uma nova configuração de país.

Isso acarretou uma nova crise de identificação russa, que corroborou o período do século XIX, em que debates sobre identidade nacional afloravam em diversos países - no Brasil inclusive, durante o Romantismo -, e a ideia da individualização, acompanhada de preocupações com características específicas de cada país. Países que "surgem" para o contexto mundial (Brasil e Rússia, por exemplo) pressupõem novas individualidades a serem estudadas.

A questão da identidade nacional, então, torna-se central quando, em 1812, a Rússia é invadida por Napoleão, representando uma entrada física da Europa no país, não mais apenas cultural. Por sua vez, a partir de Pedro I a referência de comparação é o Ocidente, fazendo com que Napoleão seja colocado acima dos mongóis - a ponto de Nikolai Karamzin (1766-1826), um dos mais importantes historiadores da Rússia, ver os acontecimentos após 1812 como imprescindíveis para a formação do Estado russo.

A importância das invasões napoleônicas é tanta que aparentemente só após elas surgiu alguma espécie de consciência nacional do povo russo. Isso se deu porque

Apesar de pouco se saber sobre o tipo de patriotismo que motivou a população comum russa a lutar contra os invasores, no entanto é um fato histórico que ela o fez e expulsou Napoleão e seus exércitos da Rússia. Isso aconteceu depois de o próprio czar Alexandre I (1801-25) apelar para a população russa defender o país. Ao colocar a defesa nacional nas mãos do povo, mesmo que por um curto período, Alexandre implicitamente enfraqueceu o mito de um imperador onipotente e divino, promulgado pelos seus antecessores, e reconheceu um papel político para o narod [povo], 
algo com o que ele não estava confortável. Logo após a guerra, entretanto, ele proclamou a vitória da Rússia e a expulsão de Napoleão da Europa central como um ato de providência divina, exercido através dele, o todopoderoso czar ortodoxo. No entanto, o paradoxo persiste: seu apelo ajudou a criar o espectro de soberania popular. Como resultado, a discussão sobre a identidade nacional russa começou a se estabelecer após 1812. (JAHN: 2004$, p. 58$)^{5}$

Sabendo disso, vemos que Alexandre I apenas procedeu, após a vitória às custas de seu apelo ao povo russo, tal qual os czares anteriores: seguindo o autoritarismo e o discurso de espiritualidade russa para centralizar o Estado russo em sua figura. Por outro lado, iniciou uma transformação nas noções de nacionalidade tanto dos intelectuais quanto do cidadão comum.

As ações de Alexandre I contribuíram, sobretudo, para o surgimento de uma nova consciência de povo russo, mas também resultaram em insatisfação de parte da inteligentsia, que se via censurada pela centralização do poder, além do proposital "esquecimento", por parte do czar, do valor que o povo teve na luta contra Napoleão. Durante as campanhas desta guerra,

[...] uma nova geração começou a surgir na Rússia, o "povo de 1812", como o historiador literário e cultural Yuri Lotman o chamou. Esse povo perseguiu Napoleão em todo o caminho até a França. No caminho, eles foram recebidos nos salões de Varsóvia, Berlim, Paris e várias outras cidades, onde eles conheceram as mais recentes ideias filosóficas e teorias políticas da Europa ocidental. Quando, por volta de 1815, voltaram para a Rússia, inevitavelmente começaram a comparar essas ideias e suas experiências pessoais na guerra com as realidades de seu próprio país. Os contrastes não poderiam ser mais óbvios. Enquanto o resto da Europa estava discutindo os direitos do indivíduo, celebrando a liberdade de nações e implementando reformas constitucionais, a Rússia continuava sendo um império autocrático, marcado por despotismo policial, censura restrita, instituição da servidão [...] (JAHN: 2004, p.58-59) ${ }^{6}$

5 No original em inglês: "Although little is known about the kind of patriotism that motivated ordinary Russians to fight against the invaders, it is nevertheless a historical fact that they did so and that they expelled Napoleon and his armies from Russia. All of this happened after Tsar Alexander I (1801-25) himself had appealed to the Russian population for help to defend the country. By putting national defence into the hands of the people, albeit for a short period, Alexander implicitly weakened the myth of an omnipotent and divine emperor, promulgated by his predecessors, and recognised a political role for the narod, something with which he was not at all comfortable. Right after the war, therefore, he proclaimed Russia's victory and the expulsion of Napoleon from Central Europe to have been an act of divine providence, exerted through him, the all-powerful Orthodox tsar. Nevertheless, the paradox remains: his appeal had helped to raise the spectre of popular sovereignty. As a result, discussion of Russian national identity started to come of age after 1812."

6 No inglês em original: "[...] a new generation began to emerge in Russia, the 'people of 1812', as the literary and cultural historian lurii Lotman has called them. These people soon chased 
Em dezembro de 1825, a situação do país descendia desses mais de dez anos de reconfiguração política e social após a vitória contra Napoleão. A chamada Revolta Dezembrista se justificava por esse contato que diversos oficiais russos tiveram com filosofias europeias diversas, além da crescente censura à inteligentsia cada vez mais intelectualizada. A morte de Alexandre I, nesse mesmo mês, junto com a revolta, teve como consequência uma repressão extrema, promovida pelo novo czar, Nicolau I.

Apesar de parecer um movimento popular, os Dezembristas não deixavam de ser parte de uma elite intelectual que só tardiamente tomou conhecimento do povo russo. Alguns de seus costumes eram ainda europeizados, tal qual o comportamento promovido pela nobreza russa no século anterior. Por outro lado, a figura do dezembrista também foi associada à conexão maior com uma população "esquecida" pelo poder político - havendo aí, nas entrelinhas, a discussão sobre o final da servidão.

Mais tarde, em 1833, Sergei Uvarov (1785-1855), então ministro da educação de Nicolau I, lançou a tríade do estadismo russo: "Ortodoxia, Autocracia, Nacionalidade", evidenciando mais uma vez o autoritarismo estatal com czar e Igreja como componentes indissociáveis da nação. Em contrapartida, a evidência (inclusive histórica) dessas autoridades, ao ser conectada à noção de uma "nacionalidade oficial", dava a sensação de paradoxo, uma vez que o Estado parecia cada vez mais

Napoleon all the way back to France. On their way, they were welcomed into the salons of Warsaw, Berlin, Paris, and many other cities, where they picked up the latest philosophical ideas and political theories of Western Europe. Once they came back to Russia around 1815, they inevitably began to compare these ideas and their personal experiences in the war with the realities of their own country. The contrasts could not have been more imposing. While the rest of the Europe was discussing the rights of the individual, celebrating the freedom of nations, and implementing constitutional reforms, Russia remained an autocratic empire, marked by police despotism, strict censorship, the institution of serfdom, [...]" 
se distanciar do povo, sobretudo após sua violenta resposta à Revolta Dezembrista.

Sob outro prisma, a tentativa de golpe de Estado e a resposta violenta são partes indissociáveis do que Karamzin entende como formação do Estado russo. São duas consequências diretas de uma afronta do povo aos valores europeus predominantes desde a construção de São Petersburgo, e sinais de que, apesar de profundamente ligados à cultura do Ocidente, os russos começavam a tentar encontrar uma identidade própria, ou, pelo menos, tentavam se aproximar dos costumes do narod.

Vimos algo semelhante no momento de quebra com Bizâncio e a tentativa de Moscou de se estabelecer como "Terceira Roma", numa evidente ruptura com um modelo cultural que foi dominante por séculos, mas que foi "superado" por uma Rússia já capaz de fazer frente ao domínio mongol. Se o modelo para Pedro I foi o norte da Europa, a França ainda era a fonte do iluminismo europeu e do comportamento da nobreza; no entanto, a guerra em 1812 promoveu esse novo rompimento.

A partir dessa espécie de independência (ainda que reprimida pelo poder estatal), testemunhou-se o surgimento de uma questão que já surgira em 1802, com Karamzin no texto "Do amor à pátria e do orgulho nacional", mas que seria trabalhada mais profundamente após o estabelecimento da "nacionalidade oficial": a Rússia era apenas uma cópia de seus dominadores? Se mesmo aqueles que se aproximavam do povo mais comum ainda reproduziam costumes de uma corte "colonizada", o que esse mesmo povo produziria de novo? E se a própria nacionalidade era dúbia, a quem ela se referia - aos Dezembristas, ao narod, ao czar..? 
O início oficial dessa discussão na própria Rússia foi em 1836, quando foi publicada (em russo) a "Primeira carta filosófica" (1829), de Piotr Tchaadáiev (17941856), integrante do "povo de 1812", na qual se lê:

O caso é que nunca andamos lado a lado com outros povos, não pertencemos a nenhuma das famílias conhecidas do gênero humano, nem ao Oriente, nem ao Ocidente, e não temos tradições nem de um, nem de outro. Estamos como que fora do tempo, a educação universal do gênero humano não se difundiu entre nós.

$[\ldots]$

Em nossas casas, parece que estamos em um alojamento; em nossas famílias, parecemos estrangeiros; nas cidades, somos todos nômades, somos pior que os nômades que pascem os rebanhos em nossas estepes, pois eles estão mais ligados aos seus desertos do que nós a nossas cidades. (TCHAADÁlEV: 1836$)^{7}$

Tchaadáiev, escrevendo no período de maior efervescência da busca por uma identidade nacional em diversas partes do mundo (aqui no Brasil, por exemplo, o Romantismo do século XIX tinha essa busca como uma das principais preocupações), coloca a Rússia numa espécie de "limbo cultural", em que não se dirigiu à Ásia - região de maior parte do território -, e vê questionadas suas semelhanças com a Europa.

A grande cisão russa no século XIX, originada a partir da "Primeira carta", entre Ocidentalistas - aqueles que acreditavam que a Rússia devia se aproximar culturalmente dos europeus - e Eslavófilos - os que combatiam a visão de uma Rússia ocidental, valorizando as tradições anteriores a Petersburgo - acompanhou o dabate da identidade nacional, e seguiu influenciando a cultura do país. Isso porque os defensores do período moscovita eram ligados a conceitos coletivizantes (inclusive na "transformação" do camponês em servos, que eram contados e vendidos em grupo), enquanto os favoráveis à europeização se voltavam à individualidade.

O "novo" indivíduo russo foi o que permitiu, por exemplo, o surgimento da

7 Tradução para o português de Cecília Rosas, de 2013. 
novela Memórias do subsolo (1864), de Fiódor Dostoievski (1821-1881), escritor russo e um dos maiores inspiradores para esta dissertação - e para toda uma cultura literária posterior. Na novela, a primeira parte é o que aparentemente revolucionou o modo de tratar o indivíduo (pelo menos na literatura) e o desenvolvimento de personagens e personalidades. A figura do "subsolo", por sinal, é interessantíssima por conter uma emergência da individualidade no contexto russo do século XIX.

Emergir, por sua vez, fazia parte da ideologia ocidentalista:

A sociedade educada e as elites não deveriam se assemelhar ao narod, como os Eslavófilos desejavam, mas deviam elevar o narod de seu alegado estado primitivo e pré-moderno por meio de conhecimento, iluminação e, mais tarde no século, também por meio de ação revolucionária. Segundo esse raciocínio, camponeses deveriam ser transformados em cidadãos, o narod deveria se tornar a nação, e a identidade nacional deveria se basear em consciência política em vez de uma obscura tradição de comunidade. (JAHN: 2004, p. 62)

Sendo assim, o cidadão "emergirá" após a adoção da modernidade europeia. Aqui também podemos assumir que foi uma revolta em relação a uma europeização ineficiente e deturpada.

A construção da consciência individual na Rússia é, portanto, derivada da violência para com grupos políticos, mas descende sobretudo de uma violenta reação ao passado - seja por parte do grupo que for, e em direção ao tempo que for. A transição do período bizantino para o moscovita; do moscovita para o petrino; e do subsolo à consciência foi acompanhada por repressão e quebra abrupta com o passado, tal qual Lotman e Uspensky previam. Não se trata de um processo em que se mesclam ideologias futura e passada, mas uma cisão entre "velhas" e "novas

8 No original em inglês: "Educated society and the elites should not become like the narod, as the Slavophiles wished, but they should rather lift up the narod from its allegedly primitive and premodern state through knowledge, enlightenment, and, later in the century, also through revolutionary action. According to this reasoning, peasants should be turned into citizens, the narod should become the nation, and national identity should be based on political consciousness rather than a murky tradition of community." 
maneiras".

É a partir dessa constituição que pretendemos analisar a obra de Pelevin, já que a esquizofrenia do protagonista participa da construção do enredo, mas podemos reconhecer uma visão do autor de que essas fragmentações culturais históricas da Rússia ainda fazem parte do indivíduo do país - em alguns momentos do livro, muito evidentemente. A "batalha" entre Eslavófilos e Ocidentalistas em especial, como veremos ao abordar os sonhos descritos no romance. 


\title{
3. PELEVIN E O PÓS-MODERNISMO RUSSO
}

\section{O "hiper" de Epstein e a fragmentação da realidade}

Ao concordarmos com Lotman e Uspensky em relação à formação da cultura russa por rupturas com o passado, também devemos levar em conta a teoria de ambos de que a unicidade da Rússia está na tentativa de completa mudança cultural - e como isso também aproximava subjetivamente a quebra ao passado. No entanto, nenhuma ruptura, em qualquer cultura, é total, pois

\begin{abstract}
Uma cultura viva não pode ser uma mera repetição do passado - ela invariavelmente dá à luz estrutural e funcionalmente novos sistemas e textos. Mas ela não pode conter apenas uma memória do passado dentro de si. Para qualquer cultura, a inter-relação entre suas imagens potenciais de passado e de futuro, e a medida em que elas interagem, é uma característica tipológica essencial, a qual deve ser levada em consideração na comparação de diferentes culturas. (LOTMAN, USPENSKY: 1984, p.28) ${ }^{9}$
\end{abstract}

Em nossa análise, percebemos que, apesar de surgirem ideologias novas à Rússia, todas acompanharam a repressão e a formação de grupos resistentes às transformações, tal qual Lotman e Uspensky estabelecem.

O mesmo aconteceu, por sua vez, na ruptura em grande escala mais recente - e, inclusive, mais conhecida: a queda do regime soviético em 1991. Após 74 anos, os socialistas - que, aliás, corrobora a dualidade observada por Lotman e Uspensky, pela divisão do mundo nos eixos capitalista e comunista - viram ruir um projeto de poder que construíram sobretudo pela negação da cultura estadunidense e de seus aliados.

9 No original em inglês: "A living culture cannot be a mere repetition of the past - it invariably gives birth to structurally and functionally new systems and texts. But it cannot but contain within itself the memory of the past. For any culture the interrelation between its potential images of the past and of the future, and the extent to which they interact, is an essential typological characteristic, one that should be taken into account in the comparison of different cultures." 
A derrocada dos soviéticos foi acompanhada por uma sensação de que, na ânsia por construir uma ideologia que combatesse a entrada de valores capitalistas na URSS, foram mascaradas a realidade e os problemas sociais oriundos do domínio socialista. Isso se evidencia na transformação que Mikhail Epstein (1958-), teórico e crítico literário russo, propõe:

Todas essas tendências [tendências sociais e intelectuais soviéticas, como "coletivismo" e "materialismo"] manifestam o fenômeno do "hiper" em seu primeiro momento, que é constituído pela derrubada revolucionária do paradigma "clássico" e uma afirmação de uma "realidade verdadeira, essencial," ou "super-realidade." No segundo momento, o mesmo fenômeno ocorre e aparece como "pseudo-realidades", assim mostrando a transformação do próprio "hiper," sua inevitável transição do estágio modernista ao pós-modernista, do "super" ao "pseudo." [...] O conceito de "hiper" evidencia não apenas a continuidade entre Modernismo e PósModernismo, mas também um desenvolvimento paralelo do PósModernismo russo e ocidental como reações e revisões de um legado "revolucionário" comum. (EPSTEIN: 1999, p.6) $)^{10}$

Mais adiante podemos ler:

A dialética pós-moderna (se ainda for possível combinar esses termos tão heterogêneos) não possui síntese nem revolução, mas uma tensão interna de ironia. A antítese, levada ao extremo, encontra a tese dentro de si, e ainda prova-se uma extensão e intensificação dessa mesma tese. A negação revolucionária se prova um enaltecimento, uma hipérbole do que é negado. A antítese circunda a tese, como sua projeção disfarçada e exagerada. (EPSTEIN: 1999, p. 25)

Epstein nos apresenta uma leitura pós-moderna de algo semelhante ao final do capítulo de Lotman e Uspensky: a cultura russa transita entre rupturas em que a antítese sempre retoma a tese, mesmo quando as ideologias envolvidas são,

10 No original em inglês: "All these trends [Soviet social and intellectual trends, such as "collectivism and "materialism"] manifest the phenomenon of "hyper" in its first stage, which is constituted by the revolutionary overthrow of the "classic" paradigm and an assertion of a "true, essential reality," or "super-reality." In the second stage, the same phenomena are realized and exposed as "pseudorealities" thus marking the transformation of "hyper" itself, its inevitable transition from the modernist to the postmodernist stage, from "super" to "pseudo." [...] The concept of "hyper" hightlights not only the lines of continuity between modernism and postmodernism, but also the parallel developments in Russian and Western postmodernism as reactions to and revisions of a common "revolutionary" legacy."

11 No original em inglês: "Postmodernist dialectics (if it is still possible to combine such heterogeneous terms) implies neither synthesis nor revolution but the internal tension of irony. Antithesis, pushed to an extreme, finds thesis inside itself, and moreover proves to be an extension and intensification of this very thesis. Revolutionary negation proves to be an aggrandizement, a hyperbole of what is negated. Antithesis circles back on thesis, as its disguised and exaggerated projection." Grifos do autor. 
aparentemente, opostas. No contexto pós-moderno, a transição de um governo soviético para uma Rússia que se abria (econômica e culturalmente) ao Ocidente mostrou a realidade soviética que se "disfarçava e exagerava", usando os termos de Epstein, enquanto antítese do mundo capitalista.

O ano de 1991 não só representou a ruína de um modelo econômico na maior parte do mundo, mas também de uma realidade construída, pois

\begin{abstract}
Historicamente, intensidade e ilusão, o "super" e o "pseudo," evoluem com o "hiper" apenas gradualmente, em duas fases sucessivas. A primeira, fase "revolucionária," é representada pelo "super." Está é a fase da entusiasmada descoberta ou construção de novas realidades: a "supersociedade" socialista, a "supersexualidade" emancipada, a "superpartícula" elementar, o "supertexto" autorreferencial, a autopropagadora "supermatéria." A primeira metade do século XX estava especialmente preocupada com o avanço dos fenômenos do "super." Eles germinaram nos anos 1900 e 1910 no solo teórico do Marxismo, Freudianismo e Nietzschianismo; nos anos 1920 e 1930, essas teorias do "super" se tornaram práticas - como revoluções social, sexual, científica, filosófica e crítica.

A seguir, na segunda metade do século $X X$, houve uma gradual identificação do aspecto "simulativo" de todos esses onipresentes superlativos. Do outro lado do "super" nós descobrimos o "pseudo." Essa transição do "super" para o "pseudo," das ilusões estáticas da realidade pura para a percepção irônica desta realidade como pura ilusão, relacionase à transformação histórica da cultura europeia e russa no século $X X$, e pode ser descrita como o movimento do Modernismo ao Pós-Modernismo. (EPSTEIN: 1999, p. 26-27) $)^{12}$
\end{abstract}

O momento da pós-modernidade é, por um lado, polêmico no que concerne a essa

denominação no Ocidente, principalmente pelas discussões suscitadas por Jürgen

Habermas - pela Escola de Frankfurt, e que vê o Pós-Modernismo como apenas

uma fase do Modernismo -, Fredric Jameson - que considera uma nova expressão

12 Em inglês no original: "Historically, intensity and illusion, the 'super' and the 'pseudo,' evolve within the 'hyper' only gradually, in two successive stages. Its first, 'revolutionary' phase is represented by the 'super.' This is the phase of enthusiastic discovery or construction of new realities: the socialist 'supersociety,' the emancipated 'supersexuality,' the self-propelled 'supermatter.' The first half of the twentieth century was mainly preoccupied with the revolutionary advancement of all these 'super' phenomena. They germinated in the 1900s and 1910s in the theoretical soil of Marxism, Freudianism, and Nietzscheanism; in the 1920s and 1930s, these 'super' theories took on practical form - as the social, sexual, scientific, philosophical, and critical revolutions.

This was followed in the second half of the twentieth century by a gradual realization of the simulative character of all these ubiquitous superlatives. On the other side of 'hyper' we discovered 'pseudo.' This transition from the 'super' to the 'pseudo,' from the ecstatic illusions of pure reality to the ironic realization of this reality as pure illusion, accounts for the historical transformation of European and Russian culture in the twentieth century, and can be described as the movement from modernism to postmodernism." 
artística acrítica -, ou até mesmo Andreas Huyssen, que reconhece o valor estético e crítico ainda em formação na arte pós-moderna; por outro lado, na Rússia é evidenciado pela transformação tanto da realidade quanto das obras que a ela se referem.

Simultaneamente ao declínio soviético, a pós-modernidade russa se desenvolvia no "subterrâneo", mas ao final dos anos 1980, "com um pequeno atraso após a 'glasnost', a literatura não-realista começou a ser reconhecida pelo establishment cultural" (LIPOVETSKY: 2001, p. 32) ${ }^{13}$. Essa simultaneidade nos permite reconhecera ruína de um modelo, seguindo a lógica de Lotman e Uspensky, haveria de ter a ascensão de um outro oposto na Rússia - não à toa, a "hipermaterialidade" soviética deu lugar à literatura da irrealidade.

Segundo Mark Lipovetsky (1964-), crítico literário e cultural russo,

De fato, a superprodução de imagens ideológicas pelo Realismo Socialista, que substituiu a realidade para a maioria absoluta do povo soviético, pode ser comparada com a simulação pós-modernista gerada pela mídia de massas e a Internet. Segundo Baudrillard, a simulação total destrói irreparavelmente a realidade: "agora é impossível de isolar o sistema do real, ou de provar o real." "O deserto do real em si" é um ponto de partida do pós-modernismo russo, que foi a primeira tendência literária capaz de não só reconhecer o caráter simulado da realidade soviética, mas também de revelar e zombar do próprio processo de produção cultural da simulação de realidade. Por causa do pós-Realismo Socialista, origem pós-simulação, o Pós-Modernismo russo teve de realizar duas tarefas simultaneamente. A primeira foi produzir imagens que "não tinham relação com nenhuma realidade: eram seu próprio simulacro". A segunda tarefa foi desmascarar "a ausência de uma realidade profunda" por meio dessas mesmas imagens. (LIPOVETSKY: 2001, p. 34) ${ }^{14}$

13 No original em inglês: "[...] with a little delay after the launch of 'glasnost', non-realistic literature began to be recognized by the cultural establishment."

14 No original em inglês: "Indeed, the Socialist Realism overproduction of ideological images that replaced reality for the absolute majority of the Soviet people, can be compared with postmodernist simulation generated by the mass-media and the Internet. According to Baudrillard, the total simulation irrecoverably destroys reality: 'it is now impossible to isolate the process of the real, or to prove the real.' 'The desert of the real itself is a starting point of Russian postmodernism, that was the first literary trend, able not only to recognize the simulative character of Soviet reality, but also to reveal and mock the very process of the cultural production of simulacra of reality. Because of its post-Socialist Realism, post-simulation origin, Russian postmodernism had to fulfil two tasks simultaneously. The first was to produce images that have 'no relation to any reality whatsoever: it is its own pure simulacrum'. The second task was, to unmask 'the absence of a profound reality' by the means of these very images." Grifos do autor. 
Podemos depreender que, atuando enquanto voz imediata de reação à ruína soviética, o Pós-Modernismo literário russo representou a ruptura em relação às realidades construídas pelo Realismo Socialista. É interessante notar o uso do termo "underground", ou subterrâneo, para se referir à literatura marginal da Rússia no final da URSS: como vimos, a figura do subterrâneo tem suma importância, não só pelo uso no título da novela de Dostoievski, mas porque é a partir dele que emerge a individualidade russa.

A emergência do Pós-Modernismo russo pelo subterrâneo cultural (ou seja, fora do discurso oficial) também é fruto da repressão de mais um momento histórico do país: a censura durante grande parte do período soviético. Isso se justificava por

A arte realista socialista não foi criada para museus, galerias, colecionadores particulares ou conhecedores. [...] O Estado socialista tornou-se o único consumidor restante de arte. E ele estava interessado somente num tipo de arte - a arte socialmente útil que apelava para as massas, que as educava, inspirava, direcionava. Consequentemente, a arte realista socialista era feita, afinal de contas, para reprodução, distribuição e consumo em massa - e não para contemplação concentrada e individual. (GROYS: 2008) $)^{15}$

Sendo a arte didática, deveria produzir somente conceitos condizentes com os valores soviéticos - e, a partir deles, criar um sentimento de união do povo na luta contra o capitalismo.

A partir do estabelecimento da glasnost, surgiu a oportunidade de vários escritores se colocarem em evidência (entre eles, Victor Pelevin). A literatura que apresenta possibilidades de (ir)realidades alternativas à soviética segue também a lógica da dualidade de Lotman e Uspensky, pois apesar da repressão estatal (figura histórica na Rússia), ainda assim se desenvolvem ideologias dissonantes no contexto histórico russo.

No entanto, a construção de uma realidade a partir de um edifício soviético

15 Tradução para o português de Virgínia Starling, de 2015. 
estabelecido e que atingiu a fase do "pseudo" significava trabalhar com um vazio do próprio real, o qual foi imposto ao povo seguindo uma linha ideológica. O escritor pós-moderno russo se depararia, então, com as possibilidades de produzir além dos ditames governamentais, permitindo-se trabalhar contra a ideologia anterior, ou até se utilizando das próprias capacidades soviéticas de criar uma ficção.

\section{Pelevin e a possibilidade de (re)construção da realidade}

Do ponto de vista criativo, a ficção soviética foi de suma importância para o desenvolvimento do potencial literário de Pelevin. Como já citamos, historicamente a repressão representou um papel importante na formação da Rússia: a partir dela, por exemplo, se deu a reconstrução de um país devastado pelo caos social, ainda que com o estabelecimento da servidão como modo de produção; em resposta, a aproximação ao Ocidente promoveu a autocrítica e surgiu a possibilidade de mobilidade social (por dívida compulsória de trabalho com o Estado, é verdade); tal possibilidade evidenciou uma individualidade antes mascarada por uma leitura de coletividade do narod; a emergência do indivíduo, saindo do "subsolo", no século XIX, produziu também o questionamento pessoal de pertença - ou não - a uma nação.

Sob o poder bolchevique, o discurso retornava à leitura da coletividade, mas não descartando que os indivíduos faziam parte de uma classe social, diferentemente de uma nacionalidade. As preocupações em relação à identidade nacional, por sinal, foram quase esquecidas, enquanto a União Soviética avançava sobre outros países vizinhos para estabelecer seus cada vez maiores domínios 
políticos e econômicos. O didatismo artístico, no entanto, imergiu ao subsolo a identidade individual, que representaria uma afronta à luta coletiva contra o capitalismo.

Desse mesmo subterrâneo da identidade, por outro lado, foram produzidas obras que, se não podiam ser (ainda) publicadas, muito por conta da censura, trabalhavam com a criação de realidades alternativas em ficções. A partir da queda dos soviéticos, não apenas foi possível emergir literariamente, mas, segundo Epstein, ficou evidente que a hiper-realidade havia se tornado pseudo. É por isso que

A memória do passado imediato permitiu a essa literatura manter uma continuidade com o período precedente - um período com o qual ela não parece querer romper. [...]

A mais óbvia, se não a única razão para esse estado, é a queda inesperadamente fácil do regime soviético. Sua estabilidade se provou ilusória; no entanto, seus fantasmas perduraram. O poder do regime sobre a realidade apenas se tornou visível após a morte do próprio regime. Sob o feitiço desses "necroefeitos", a cultura contemporânea está lutando para assimilar os mecanismos com os quais o regime criou - e com muito mais sucesso do que se pensava - sua própria realidade. (GENIS: 1999, p. 212) ${ }^{16}$

Este trecho de Alexander Genis (1953-), crítico cultural, nos leva a pensar na ficção pós-soviética não diretamente como uma continuidade da arte didática, que "aprendeu" a criar realidades tais quais os soviéticos, mas como uma ainda jovem forma de criação que dialoga com o passado recente. Pelevin é uma das vozes mais fortes dessa geração, tanto pelo sucesso literário quanto pelo trabalho com a irrealidade em seus romances - ou melhor, com as realidades alternativas.

A fronteira entre as realidades, na Rússia, passa pela fragilidade entre as dualidades culturais e, também, pelas rápidas transformações que essa fragilidade

16 No original em inglês: "The memory of the immediate past has allowed this literature to maintain a continuity with the preceding period - a period with which it apparently does not want to break. [...] The most obvious, if not the only reason for this state of affairs, is the unexpectedly easy fall of the Soviet regime. Its stability proved illusory; nonetheless, its ghosts have endured. The regime's power over reality has become manifest only after the death of the regime itself. Under the spell of these necroeffects, contemporary culture is striving to assimilate the mechanisms with which the regime created - and much more successfully than was previously thought - its own reality." 
proporciona. Não à toa, a ficção de Pelevin é "fronteiriça", fluindo na "fronteira entre diferentes mundos" (GENIS: 1999, p.217); por outro lado, a tomada de consciência da falsa realidade soviética nos permite compreender que a própria população russa passou a viver uma reconstrução do mundo em que vive.

A compreensão de que um mundo que se apresentava indiscutivelmente sólido ruiu requer um novo conhecimento para conseguir conviver com a destruição do passado e se estabelecer no futuro. A tomada de consciência, o autorreconhecimento do povo russo, após 1991, é mais uma batalha que o país teve de lutar para compreender sua identidade.

Os mesmos fantasmas a que se refere Genis são, na verdade, dogmas estabelecidos para controlar o próprio mundo que os soviéticos viviam, e com eles impunham a identidade aos subordinados. Ainda segundo o crítico,

Para os autores pós-soviéticos, o mundo ao redor representa uma sequência de constructos artificiais, nos quais o Homem está eternamente fadado a procurar por uma realidade "pura," "arquetípica." Apesar de esses mundos paralelos não serem "verdadeiros" em nenhum sentido absoluto, eles também não são "falsos," pelo menos enquanto alguém acreditar neles. Cada versão do mundo existe apenas na alma de cada indivíduo.(GENIS: 1999, p. 215) ${ }^{17}$

Da ruína do poder soviético surgiu a inspiração para a construção da ficção póssoviética. Em contraposição ao chamado Realismo Socialista, uma forma de "pósRealismo" abordando a irrealidade encontrou seu mecanismo no movimento passado, não deixando de existir, nessa apropriação, uma crítica indireta que inclui a continuidade de realidades "frágeis" muitas vezes tratadas como definitivas.

Isso não deixará de refletir na obra de Pelevin, seja nos contos, seja nos romances. Podemos exemplificá-lo com o primeiro romance do autor, Omon Ra, em

17 No original em inglês: "For the post-Soviet authors, the world around them represents a sequence of artificial constructs, in which man is forever doomed to search for a 'pure,' 'archetypal' reality. Although these parallel worlds are not 'true' in any absolute sense, they are not 'false' either, at least as long as someone believes in them. Each version of the world exists only in each individual soul." 
que um grupo de jovens participa da missão espacial soviética em direção à Lua, mas acaba por descobrir que o projeto é simplesmente uma farsa; ou na coletânea Vida dos insetos, em que insetos são humanizados desde a busca de besouros-doesterco por uma transcendência enquanto empurram fezes à frente, até discussões metafísicas entre mariposas que tentam questionar sua finalidade de voar em direção à luz.

Também há uma marcante divisão no que concerne a Pelevin em dois aspectos: ao mesmo tempo em que se preocupa em criar uma imagem de "nãoescritor", de se desvencilhar da socialização do âmbito das celebridades literárias, sua abrangência à Internet, com boa parte das obras publicadas neste meio, também se transforma em parte de seu perfil. Esse apreço pelas novas tecnologias, por exemplo, é evidente em $\mathrm{O}$ elmo do horror, em que o autor transpõe o mito de Teseu e o Minotauro para uma sala de bate-papo.

Por fim, podemos perceber que Pelevin apresenta uma dualidade entre a figura misteriosa, isolada, que procura ser ligada a um aspecto até antissocial, e uma produção que aborda realidades ligadas à vida "comum" - em especial verdades assumidas e questionáveis da Rússia pós-soviética; e, por outro lado, se mostra atualizado em relação às novas fontes tecnológicas. Seu trânsito entre esses dois perfis o transformou em parte da cultura de massa russa, fazendo-o o escritor mais vendido do país durante anos e marcando seu nome na cultura pop da Rússia atual.

Sabendo da dualidade entranhada no passado da cultura russa e na construção social desse autor, já se pode iniciar a leitura de $A$ metralhadora de argila sob essa perspectiva: o título em russo é Tchapaiev i Pustota, dois sobrenomes. A princípio, o primeiro é uma referência à figura histórica Vassili Ivanovitch Tchapaiev 
(1887-1919), comandante do Exército Vermelho durante a Guerra Civil Russa; o segundo nome, por sua vez, curiosamente significa vazio em russo, o que será de suma importância para nossa análise mais à frente.

Incluir A metralhadora de argila neste contexto dual também respalda uma marca do estilo de construção da narrativa de Pelevin, pois

\begin{abstract}
A metralhadora de argila [...] é em muitos aspectos uma espécie de soma dos temas que Pelevin desenvolveu durante os seis anos anteriores [do início da publicação de seus contos ficcionais até a publicação desse livro, em 1996]. Os dois protagonistas do romance formam outro dos pares "professor-aluno" tão comuns nas obras de Pelevin. Ambas as personagens, no entanto, são construídas de uma maneira que carecem de qualquer substanciabilidade. (MCCAUSLAND: 2003, p. 217)
\end{abstract}

Desse modo, a dualidade não só se faz presente no histórico russo, mas reverbera no protagonismo dialógico nas obras de Pelevin.

Neste romance, Pelevin não só trabalha com essa esquizofrenia social da dualidade e ruptura, mas também utilizando-se dessa mesma esquizofrenia como catalisadora na criação de realidades. Os diferentes mundos, tal qual Genis citou, residem no protagonista, que narra o romance em primeira pessoa, mas que apresenta algumas questões históricas da formação da identidade dele $-\mathrm{e}$ da Rússia.

O trabalho do autor aqui estudado contribui para que reconheçamos, por um lado, a ainda incompletude de uma identidade nacional russa, e, por outro, o ilimitado potencial de criação de realidades, oriundo de um passado recente. Os sonhos dos detentos, colegas do protagonista, são indispensáveis para a primeira discussão; por sua vez, a jornada de autorreconhecimento se dá com a possibilidade que esse mesmo protagonista tem de criar e aceitar suas próprias realidades

18 No original em inglês: "Chapaev i Pustota [...] is in many ways a kind of summation of the themes that Pelevin developed over the course of the preceding six years. The two protagonists of the novel form another of the teacher-protégé pairs so typical of Pelevin's works. Both of these characters, however, are constructed in such a way that they lack any real substance." A informação entre colchetes na tradução é de autoria nossa. 


\section{A METRALHADORA DE ARGILA: SONHOS E IDENTIDADE}

Até agora vimos um panorama histórico que acarretou o surgimento de uma consciência de identidade russa pautada em transições e embates em diversas esferas da vida social. A quebra significativa com um passado recente, representada pela ruína soviética e a necessidade de reestabelecimento da Rússia como país num mundo à beira da globalização, não deixa de influenciar a produção de Pelevin.

Escrito em 1996, A metralhadora de argila não só permeia a transição de poder em 1991, mas também as dificuldades de adaptação de personagens ao novo mundo que surge. Quando de sua publicação, criou polêmica por, num momento de reestruturação, revisitar a figura de Tchapaiev com uma linguagem agressivamente irônica; por outro lado, parte da crítica literária reconheceu que a ausência dessa obra no Russian Booker Prize de 1996 como uma falha inexplicável da premiação.

Se, num contexto externo, A metralhadora de argila apresentou uma cisão da crítica (assim como o próprio autor divide opiniões), sua construção se dá desde um hospício poucos anos antes de sua publicação, até a ação nos sonhos de um protagonista que acredita viver em 1919. Embates internos e externos em relação a esse romance são parte indissociável daquilo que acreditamos ser seu trunfo literário, que carregará consigo a esquizofrenia como suporte para a fiç̧ão.

Sabendo que há um protagonista que nos narra um "diário" de ações, iniciaremos a análise pelos sonhos de seus colegas de hospício, atribuindo a cada um uma parte histórica da Rússia que, por fim, participará da formação desse mesmo protagonista. 


\title{
1. Maria ocidentalista
}

O segundo capítulo de $A$ metralhadora de argila é o primeiro que apresenta um sonho paralelo à narrativa principal, realizada por Piotr, o protagonista. Se no primeiro é construída uma ambientação em 1919, com ele sendo perseguido por oficiais do Exército Vermelho e, trocando de identidade, se salvando da execução por ser um suspeito para o Estado, vemos no segundo um ambiente transformado, com personagens familiares, mas em outro local e outro tempo: um hospício em 1991.

A importância do período será tratada mais à frente, sobretudo no que concerne a Piotr e seu autorreconhecimento; por outro lado, o hospício é de suma relevância, pois pressupõe a patologia mental e, quando nos deparamos com outras personagens, há um contato direto com a relação entre o protagonista e esse segundo momento do romance. É aí que surge o psicoterapeuta Timur Timurovitch, que trata um grupo de doentes do qual Piotr passa a fazer parte.

Apresentando o procedimento adotado, Timurovitch explica:

\begin{abstract}
"Simplificando, [o método do hospital] funciona com pacientes unindo esforços na luta pela recuperação. Imagine que, por um certo tempo, seus problemas se tornam os problemas coletivos, que por um certo tempo todos que participam de uma sessão compartilham da sua condição. Todos eles se identificam com você, por assim dizer. Qual você acha que seria o resultado?"

Eu não respondi.

"É muito simples," Timur Timurovitch continuou. "Quando a sessão chega ao fim, manifesta-se uma reação enquanto os participantes saem do estado que experimentavam como realidade; você poderia chamar isso de explorar o instinto humano de rebanho a serviço da medicina. Suas ideias e seu humor podem infectar os outros que participam da sessão por um certo tempo, mas assim que a sessão chega ao fim, eles retornam às próprias obsessões maníacas, te deixando isolado. E naquele momento - desde que o material psíquico patológico seja levado à superfície pelo processo de catarse - o paciente pode tomar consciência da subjetividade arbitrária de suas próprias noções mórbidas e deixar de se identificar com elas." (PELEVIN: 1999, p. 38) ${ }^{19}$
\end{abstract}

19 No original em inglês: "To put it simply, it means patients pooling their efforts in the struggle for 
Devemos, então, levar em consideração que Piotr nos carregará não apenas pela sua própria realidade, mas também pelas sessões com outros pacientes. Timurovitch, por sua vez, nos coloca frente a uma metodologia que, assim como vimos nas análises sobre o Pós-Modernismo russo, permite a criação de diferentes realidades no romance.

Um detalhe muito importante para que entendamos a primeira sessão da qual Piotr participa é o fato de ser o primeiro momento em que $A$ metralhadora de argila é narrado em terceira pessoa. Maria, primeira paciente que "guia" o leitor pelo sonho, é um homem que se reconhece como mulher - o que pode suscitar muitos debates sobre questões de gênero e identidade, uma problemática muito recorrente na Rússia atualmente, e que tem bases históricas num passado patriarcal, inclusive oficializado no já citado Domostroi, mas não é neste aspecto que pretendemos nos ater.

Quando descreve Maria a Piotr, Timurovitch descreve-a como um caso em que há um "confronto entre objetos da consciência aparentemente tão diversos como uma novela mexicana [Simplemente María, de 1989], um blockbuster de Hollywood e nossa jovem democracia russa sem raízes" (p. 39) ${ }^{20}$. Ele vê a identificação com a Rússia como algo subconsciente, o que pode nos remeter à

recovery. Imagine that for a time your problems become the collective problems, that for a certain time everyone taking part in a session shares your condition. They all identify with you, so to speak. What do you think the result of that would be?'

I did not answer.

'It's very simple,' Timur Timurovich went on. 'When the session comes to an end, a reaction sets in as the participants withdraw from the state that they have been experiencing as reality; you could call it exploiting man's innate herd instinct in the service of medicine. Your ideas and your mood might infect the others taking part in the session for a certain time, but as soon as the session comes to an end, they return to their own manic obsessions, leaving you isolated. And at that moment - provided the pathological psychic material has been driven up to the surface by the process of catharsis - the patient can become aware of the arbitrary subjectivity of his own morbid notions and can cease to identify with them. [...]"'

20 No original em inglês: "[...] the clash of such apparently diverse objects of consciousness as a Mexican soap opera, a Hollywood blockbuster and our own young, rootless Russian democracy." 
ideia do subterrâneo em contato com a volta de conteúdos ocidentais ao país.

Maria já nos aparece como uma representação da cultura nova que adentrava a Rússia em 1991 (ano do hospício) e explicitamente de valores muito identificados com a América (México, Hollywood e até o termo "democracia" são referências às novidades para o país). Por outro lado, também há nuances nessa construção da identidade de Maria que podemos perceber, tais como a falta de raízes para esse novo modelo de sociedade, a ideia de grandes sucessos dos até recentemente rivais políticos e até a comparação com um país que faz fronteira com os EUA.

A nossa leitura de Maria enquanto simbologia para a ideologia ocidentalista se baseia nessa apresentação inicial, mas também em elementos do sonho que ela compartilha com Piotr. Este, ao relatar o sonho, é um narrador onisciente, o que nos retoma à questão da sessão: para que tome consciência de si próprio, Piotr deve acompanhar - e talvez se identificar com - o delírio de sua colega de tratamento, assim tentando se livrar de suas próprias ilusões.

Somente após a influência ocidental sobre a estrutura social russa se fez presente a figura do indivíduo e de todas as suas complexidades, tais quais a questão de gênero. Maria e Piotr são indivíduos diferentes a serem tratados por Timurovitch, de maneira que é o primeiro momento de alteridade na narração do romance pelo protagonista.

Assim que se inicia o sonho, somos levados a uma realidade em que soldados portam rifles automáticos em meio a uma névoa em que se viam letreiros com o escrito "Bureau de Change", ou câmbio monetário. A transição para uma cultura globalizada é evidente, principalmente pela utilização da língua francesa, numa releitura da cultura após o século XVIII, mas é ainda mais óbvia ao Maria 
imaginar a situação como uma gravação de filme próxima à Casa Branca, ou a referência à batalha entre russos para descobrir quem é o mais "novo".

Novamente surge a divisão entre o "novo" e o "velho" de Lotman e Uspensky, mas numa releitura que retoma a resistência à cultura europeia e a aceitação de seus valores. Não à toa a figura que salva Maria, em meio às figuras de soldados com rifles em mãos, portava os termos "Noivo, Visitante, Patrocinador" (p. 45), ou seja, a chegada de um "casamento" vindo do "Oeste" para um cidadão russo:

Ela olhou ao redor, se orientando aproximadamente pelo sol, e apontou seus braços para o Oeste - de alguma maneira, parecia óbvio que o Noivo apareceria daquela direção.

"Venha!" ela pediu baixinho, e imediatamente ela conseguiu sentir que uma nova presença aparecera no mundo. (PELEVIN: 1999, p, 45) ${ }^{21}$

Maria surge, em seu sonho, com o poder de evocar o Ocidente para que se salve do campo de batalha, além de apresentar o casamento como uma união entre o mundo russo e o ocidental. Por outro lado, inclui um novo elemento antes desconsiderado no embate histórico: a presença dos EUA. Se no passado a Europa era o modelo - ou a cultura a ser criticada -, em 1991 a participação estadunidense surge para o estabelecimento de uma nova sociedade russa.

O novo momento cultural, após a queda da realidade soviética, permitiu que diversas etnias lutassem por independência, num grande e veloz movimento separatista que formou novas fronteiras - no mínimo, geográficas - no território antes da URSS. Um indivíduo soviético já não era identificado, mas se diferenciava em diversas nações; por isso

O final da URSS não apenas trouxe a independência de diversas nacionalidades soviéticas; ele também permitiu à Rússia se dissociar do legado soviético. Na Rússia capitalista atual, o negócio de criação de

21 No original em inglês: "She looked around, orientating herself approximately by the sun, and held out her arms towards the West - somehow it seemed clear that the Bridegroom would appear from that direction.

'Come!' she prayed in a whisper, and immediately she could sense that a new presence had appeared in the world." 
identidade cresce por todo lugar. [...] No nível político, a articulação de um programa de cinco anos do Ministério da Educação e do Ministério da Defesa anunciado em 2001 almejava "estimular sentimentos de orgulho em russos por seu país ao aumentar programações pró-Rússia na televisão e vendendo souvenirs patrióticos". [...] Esse tipo de neo-eslavofilismo foi equilibrado pela política externa do presidente Vladimir Putin, procurando apresentar a Rússia como um país ocidental e parte de uma herança comum europeia. (JAHN: 2004, p. 64-65) $)^{22}$

Entre independências, liberdade de nações antes dominadas pelo sistema soviético e a dúvida de qual caminho tomar para o novo país que se configurava na Rússia, a identidade nacional continuava a transitar entre um país europeu ocidental e um passado tradicional que, por muito tempo, tentou se distanciar desse centro cultural. O indivíduo pós-soviético se via em uma espécie de esquizofrenia da cultura do país, que, num movimento pendular, propunha passado e futuro simultaneamente.

Maria é tratada por se identificar não só com o Ocidente, mas com algo ainda mais extremo, de um continente que nunca havia participado do embate cultural russo histórico. Fica mais evidente nossa proposta de que ela é a personagem ocidentalista quando sabemos quem é a personagem que compartilha o ambiente do sonho com Maria: Arnold Schwarzenegger. O casamento dela com um ator de Hollywood, mas nascido na Áustria, país europeu de cultura germânica, é o que a salva da batalha que se dava ao seu redor (num filme ou entre os "novos russos").

A descrição do noivo, aliás, relembra o discurso dos Eslavófilos em relação ao mundo europeu: forjado em metal, sua face não apresentava nenhuma expressividade, o que contrariava o papel da Rússia de baluarte da espiritualidade,

22 No original em inglês: "The end of the USSR brought not only the independence of many Soviet nationalities; it also allowed Russia to dissociate herself from the Soviet legacy. In today's capitalist Russia, the business of creating identity flourishes everywhere. [...] On the political level, a joint five-year programme of the Ministry of Education and the Ministry of Defence announced in 2001 aimed to 'arouse feelings of pride in Russians for their country by increasing pro-Russian programming on television and selling patriotic souvenirs'. [...] This type of official neoSlavophilism was counterbalanced by President Vladimir Putin's foreign policy, seeking to present Russia as a Western country and as part of a common European heritage." 
sobretudo após a queda de Bizâncio - tanto pela materialidade, artificialidade e desumanidade. Schwarzenegger, lembrado por Pelevin na personagem mais icônica de sua carreira no cinema estadunidense (o androide de O Exterminador do Futuro, filme de 1984), carrega consigo o papel de dualidade em relação à Rússia passada versus o Ocidente, e também em relação ao presente (1996) e ao futuro, seja pela apresentação do blockbuster, seja pela ficção científica construída no filme.

No entanto, a aparição dessa figura ocidental vai além da obviedade com Pelevin:

\begin{abstract}
Schwarzenegger colocou sua mão sobre o ombro dela. Maria afundou levemente sob esse peso, e repentinamente sua memória trouxe algo inesperado: uma figura de Lênin carregando uma viga em um dos "sábados de trabalho" comunistas. Na figura, apenas a ponta da viga era visível sobre o ombro de Lênin, e Maria pensou que talvez não fosse uma viga, mas a mão de uma criatura poderosa à qual Lênin apenas podia olhar com um sorriso indefeso, como ela olhava agora para Schwarzenegger. (PELEVIN: 1999, p. 47$)^{23}$
\end{abstract}

A comparação entre Maria e Vladimir Ilyich Ulyanov (1870-1924), mais conhecido como Lênin, um dos maiores líderes políticos da Revolução Russa de outubro de 1917, mostra que a Rússia de 1991 (ano em que se passa a história no hospício) passava por um momento de revolução social. A contrapartida está no sistema de governo e econômico que se estabeleceu, mas também - para esta pesquisa, mais importante - na figura que surge como a poderosa sobre os ombros de Maria e Lênin.

Se no sonho não aparece a entidade poderosa que estava "acima" de Lênin, sabemos que Schwarzenegger é a criatura que exerce poder sobre Maria, e, com ele, todo um constructo ideológico do Ocidente. Maria, que "dizem parecer ter 18

23 No original em inglês: "Schwarzenegger put his hand on her shoulder. Maria sank slightly under the weight, and suddenly her memory threw up something unexpected, a picture of Lenin carrying a beam at one of those communist working Saturdays. In the picture only the edge of the beam could be seen above Lenin's shoulder and Maria thought that perhaps it wasn't a beam after all, but the hand of some mighty creature at which Lenin could only glance up with a defenceless smile, as she was now glancing up at Schwarzenegger." 
anos" (p. 40), simboliza a juventude da democracia russa (segundo Timurovitch), além de ressaltar a entrada da cultura ocidental na nova Rússia pós-soviética. Seguindo a lógica de Pelevin, essa nova configuração de país "afunda levemente" sob as mãos de uma imposição cultural externa, e Schwarzenegger não foi uma figura aleatória para essa referência.

Em seguida à memória de Maria, o "casal" caminha em meio a um nevoeiro, que Schwarzenegger diz ser uma gravação da CNN, e tentam sair daquele campo de batalha. Maria não sabe para onde estão indo, mas seu noivo a carrega pelo braço sem hesitar, e, ao ser questionado sobre o rumo, apenas dá um sorriso. A nova Rússia, então, está sendo puxada pelo Ocidente, mas desconhece o destino.

Quando estão prestes a sair do nevoeiro, Maria percebe uma dúvida na postura de Schwarzenegger, o que ela teme ser um questionamento sobre o casamento com ela. Com isso, ela pensa em algo romântico a dizer, e então pede que o noivo a leve consigo em direção ao céu, lamentando por ser tão "ligada à terra" (p. 50). Uma Rússia muito ligada às suas raízes - ainda que, conforme vimos, não fossem únicas e definitivas historicamente - seria elevada não pela espiritualidade, mas pela máquina do Ocidente.

Essa relação é fortalecida pela expressão "alchemical wedlock", remetendo ao conceito alquímico de casamento perfeito, em que não há duas unidades que compõem o casal, mas metades já predestinadas a se juntarem para adquirir o conhecimento. Maria simboliza uma união há muito defendida pelos Ocidentalistas, em que a Rússia deveria se aproximar da Europa e de seus valores culturais.

O caminho pelo qual o casal segue termina em uma espécie de hangar, onde há um jato de guerra, pelo qual Schwarzenegger parece nutrir um amor que Maria 
inveja. O jato possui apenas lugar para um ocupante, então Maria precisa se sentar na fuselagem entre as asas, enquanto o noivo pilotará - mais uma vez a ideia do Ocidente sendo o "piloto" dos rumos da Rússia aparece.

Um detalhe interessante da abrangência cultural de Pelevin está no momento da decolagem do jato: Schwarzenegger pergunta a Maria o que ela escutava nos fones de ouvido, e a resposta é "Jihad Crimson", depois explicado como "Nushrat Fatekh Ali Khan e Robert Fripp" (p. 53). Aqui nos é trazido 1) o grupo Crimson Jihad, vilão do filme True Lies (1994), também estrelado por Schwarzenegger; 2) o músico Nushrat, paquistanês, considerado um dos maiores cantores já gravados - também inovador no estilo musical qawwali, do qual era mestre, ao introduzir estilos "ocidentais" em suas músicas; e 3) Robert Fripp, listado pela revista Rolling Stones como um dos 100 maiores guitarristas de todos os tempos, integrante da banda King Crimson.

A mistura que Pelevin faz desses elementos nos mostra um autor que tem conhecimento da cultura pop de Hollywood, mas que transita também pela música britânica e até paquistanesa. A nova Rússia (Maria) acompanha essas diversas fontes culturais, mas até a referência asiática (Nushrat) se abre à influência ocidental.

Voltando à decolagem, o jato ergue-se em frente a uma janela pela qual Maria consegue ver uma televisão em que um tanque vira seu canhão em direção ao avião. No momento em que o tanque atira, Schwarzenegger tira o jato de frente da janela, numa referência evidente à realidade em que o sonho de Maria ocorria: de um filme de ação hollywoodiano.

No movimento de manobra do jato, Maria quase cai, e então se inicia uma 
cena de conteúdo sexual explícito: Schwarzenegger pede que ela segure em uma antena que surge à sua frente, que a lembra não só um pênis, mas também "formas estranhas, não-terrestres de vida e amor" (p. 54) ${ }^{24}$. Por fim, nos é descrito que

\begin{abstract}
Maria decidiu que o que estava acontecendo com ela agora deveria ser um sonho de infância se tornando realidade. Em algum filme ou outro, ela perdeu muito tempo se debruçando sobre contos de fadas de livros, olhando as imagens e se imaginando voando pelo céu nas costas de um dragão ou de um grande pássaro, e agora isso estava realmente acontecendo. Talvez não exatamente como ela sonhou, mas então ela pensou, enquanto pousava a palma da mão na antena de aço, sonhos não se realizam da maneira que esperamos. (PELEVIN: 1999, p. 54) ${ }^{25}$
\end{abstract}

O que podemos reconhecer de ocidentalista neste trecho é o sonho de

infância do voo, já que o grande trunfo dos Ocidentalistas estaria numa ligação intrínseca com a Europa, o que estaria representado além do território, mas na cultura. O caminho por sobre o solo em direção ao Ocidente seria não só o "casamento alquímico" da Rússia, mas também uma espécie de "sonho de infância" do país.

A imagem da masturbação da antena enquanto é carregada em direção ao céu, por outro lado, é contraposta à visão que Maria tem durante a subida: a cidade de Moscou. Evidentemente, o solo ao qual ela é muito ligada - e do qual se desligará ao decolar com o noivo - é exatamente o da cidade que representa a tradição anterior à ocidentalização.

Não à toa, ao ver Moscou sob si,

Apesar da revoltante feiura de cada um de seus componentes, vista como um todo a cidade parecia extremamente linda, mas a fonte desta beleza estava além da compreensão. É sempre assim com a Rússia, pensou Maria, enquanto passava as mãos de cima a baixo no metal frio - quando você a vê de longe, é linda o suficiente pra te fazer chorar, mas quando

24 No original em inglês: "[...] strange, non-terrestrial forms of life and love."

25 No original em inglês: "Maria decided that what was happening to her now must be a childhood dream coming true. In some film or other she had spent a lot of time poring over fairy-tales in books, looking at the pictures and imagining herself flying through the sky on the back of a dragon or a huge bird, and now it was actually happening. Maybe not exactly the way she'd dreamed it, but then, she thought as she laid her palm on the steel projection of the antenna, dreams don't always come true in the way we expect." 
você vê de perto, você apenas quer vomitar. (PELEVIN: 1999, p. 55) $)^{26}$

O desejo de se desligar da tradição russa é compatível com o pensamento ocidentalista, segundo o qual o atraso cultural era representado pelo período moscovita, e a nova Rússia deveria se aproximar da Europa e de seus valores.

Podemos reconhecer diversos elementos que corroboram isso, tais como o avanço tecnológico representado pelo jato; a beleza visível apenas com o afastamento em direção ao céu; ou até o gozo de Schwarzenegger ao carregar Maria para longe do solo. O metal e a materialidade consumam o casamento, também elevando Maria além dos domos das igrejas - evidente distanciamento do espiritual que Moscou representa.

Em contrapartida, após a ejaculação o noivo se transforma de forma explícita, sobretudo ao tirar os óculos, quando nos deparamos com mais evidências de o que Schwarzenegger representa:

Seu olho esquerdo estava meio fechado de uma maneira que expressava
uma variedade de sentimentos absolutamente clara e ao mesmo tempo
imensuravelmente complexa, incluindo uma mistura estritamente
proporcional de paixão pela vida, força, um amor saudável por crianças,
apoio moral à indústria automotiva americana em sua difícil batalha com a
japonesa, reconhecimento dos direitos das minorias sexuais, uma atitude
levemente irônica em relação ao feminismo e uma certeza de que a
democracia e os valores judaico-cristãos iriam finalmente dominar todo o
mal deste mundo. (PELEVIN: 1999, p. 56$)^{27}$

Podemos reconhecer uma referência simples logo de início: na cartografia comum, eurocentrista, a Europa fica à esquerda da Rússia - portanto, o olho esquerdo seria

o europeu. No entanto, a obviedade está nos "valores judaico-cristãos" que

26 No original em inglês: "Despite the revolting ugliness of its component parts, viewed as a whole the city looked extremely beautiful, but the source of this beauty was beyond all understanding. That's always the way with Russia, thought Maria, as she ran her hands up and down the cold steel - when you see it from afar, it's so beautiful it's enough to make you cry, but when you take a closer look, you just want to puke."

27 No original em inglês: "His left eye was half-closed in a way that expressed an absolutely clear and at the same time immeasurably complex range of feelings, including a strictly proportioned mixture of passion for life, strength, a healthy love for children, moral support for the American automobile industry in its difficult struggle with the Japanese, acknowledgement of the rights of sexual minorities, a slightly ironical attitude towards feminism and the calm assurance that democracy and Judaeo-Christian values would eventually conquer all evil in this world." 
salvariam o mundo, e já haviam começado ao salvar Maria.

Por outro lado, o olho direito não é descrito como o oriental, mas surge como a inexpressividade e o maquinário, coerente com o androide do filme referente a Schwarzenegger. Os óculos, ao serem retirados, não só retomam a visão de Maria de que os sonhos nem sempre ocorrem conforme o esperado, mas também são mais uma referência ao que nos é dito sobre a Rússia (em relação à beleza à distância).

O gozo do Ocidente, podemos depreender, está não só ligado a ter poder sobre os rumos da nova Rússia, mas também em se divertir com essa posição de "piloto". O olho direito aterrorizador, frio, é o elemento que assusta Maria, mas ela percebe não ter autoridade em relação ao noivo, sobretudo com o visível riso de Schwarzenegger durante manobras com o jato, mesmo frente aos pedidos para parar.

Pelevin parece construir um Ocidente que se aproveita da fragilidade dessa Rússia que se forma ao mostrar a impotência de Maria em relação ao comando de Schwarzenegger, que a submete a seus "jogos de amor" (p. 57). E, por fim, quando Maria se recusa a continuar a aprazer o noivo, a resposta é “'Okay,' disse Schwarzenegger. 'Você está demitida.'” (p. 58) ${ }^{28}$.

Curiosamente, Pelevin mostra por meio de Maria que a aproximação da Rússia ao Ocidente não passa de um sonho. Isso porque

É significativo para o entendimento da construção das imagens russas sobre o Ocidente e a Europa que, no momento em que "Ocidente" e "Europa" se tornavam os principais componentes da identidade russa, na Europa ocidental uma imagem da periferia oriental da Europa cristã (Europa oriental) era solidamente apresentada como não-europeia. [...] Intelectuais do Leste europeu, com russos à frente, lutavam contra essa percepção na tentativa de expandir as fronteiras da Europa, rejeitando o discurso exclusivista dos europeus ocidentais. Deve ser lembrado que eles trabalhavam com os parâmetros de uma visão eurocêntrica, baseados na

28 No original em inglês: “'Okay,' said Schwarzenegger. 'You're fired."” 
crença na superioridade da "civilização europeia" manifesta em seus êxitos culturais e progresso científico e tecnológico. (TOLZ: 2010, p. 197-198) (9) $^{29}$

Ou seja, a desilusão de Maria acompanha a tentativa histórica de europeização da Rússia que, enquanto tenta se aproximar de um modelo cultural, é desconsiderada por aqueles que almeja alcançar.

O final do sonho de Maria é uma alusão muito evidente ao movimento de contraposição cultural que já vimos em Lotman e Uspensky, pois a dualidade histórica entre Rússia e Ocidente impede que a simples fuga e o casamento entre ambos signifique um catarse puro para o russo pós-soviético. A consumação do casamento não transformou Maria em ocidental, mas a levou a perceber que a apropriação dos novos valores se dá sob a custódia do novo poder cultural.

Mais uma vez nos vemos diante do autoritarismo imposto à sociedade russa: a ideia de liberdade, de autonomia em relação ao passado histórico e elevação de uma personagem rumo a valores que reconhecem sua individualidade (como os direitos de minorias sexuais no olho de Schwarzenegger, no caso de Maria), é subordinada ao poder que o noivo tem sobre a nova Rússia. Esta, por sinal, estaria submetida não só àquele olho esquerdo, mas também à artificialidade do olho direito, relembrando até uma característica muito criticada em relação a São Petersburgo, conforme já vimos na pesquisa histórica.

Por fim, acompanhamos o retorno de Maria ao hospício - consequentemente à consciência de Piotr, que nos narrava o sonho da outra detenta. Ao ser "demitida"

29 No original em inglês: "It is significant for the understanding of the construction of Russian images of the West and Europe that, at the same time when 'the West' and 'Europe' were becoming the central components of Russian identity, in western Europe an image of the eastern periphery of Christian Europe (eastern Europe) was consistently presented as not quite European. [...] Eastern European intellectuals, with Russians at the forefront, struggled against this perception in the attempt to broaden the boundaries of Europe, rejecting the exclusionist claims of western Europeans. It should be remembered that they operate within the parameters of a Eurocentric vision, based on a belief in the superiority of 'European civilisation' as manifested in its cultural achievements and scientific and technological progress." 
por seu noivo, ela volta à realidade da nova Rússia, que não compartilha o poder com o "Ocidente salvador", mas sofreu mais uma desilusão ao achar que seria transformada em parte desse mundo ocidental.

Mais interessante ainda é o acontecimento posterior no hospital: sendo reapresentados ao ambiente de Piotr, ele se diz sonolento (p. 59) num momento em que alguém, num canto da sala, pede para ligarem o rádio. Emana do aparelho um comentário sobre um grupo chamado "Inflamed Ovaries", ou, em tradução livre e contextual, "Ovários Raivosos", composto apenas por mulheres que tocavam instrumentos tão pesados quanto um tanque - mas, apesar de tal modernidade de equipamento, reproduziam uma visão própria da música clássica de Mozart. Portanto, o que nos aparece são diversos elementos que retomam o sonho de Maria: a mulher no plano central, a referência à guerra (os tanques, o jato) e à Áustria (Schwarzenegger e Mozart).

Apesar de essas referências parecerem ser um ponto final ao sonho de Maria, o que acompanhamos depois pode ser ainda mais importante: Piotr, sonolento, acaba por dormir ao início da música no rádio. A partir disso, ele narra:

[...] então tive um breve pesadelo sobre um americano usando óculos escuros, que parecia dar continuidade à história conta pela infeliz Maria. $\mathrm{O}$ americano pousou seu avião num gramado, encharcou-o com querosene e ateou fogo. [...] Então houve uma lacuna em meu sonho, e na vez seguinte em que o vi - o horror dos horrores! -, ele estava grávido: o encontro com Maria obviamente não deixou de ter consequências. (PELEVIN: 1999, p. 61) ${ }^{30}$

O que Pelevin nos indica neste final de capítulo (e de sonho) é uma releitura das desilusões russas em relação aos modelos culturais que seguirá: não é Maria que ficará grávida, mas a figura ocidental.

30 No original em inglês: "[...] then I had a brief nightmare about an American wearing dark glasses which seemed to continue the story told by the unfortunate Maria.

The American landed his plane in a yard, soaked it with kerosene and set fire to it. [...] Then there was a gap in my dream, and the next time I saw him - horror of horrors! - he was pregnant: the encounter with Maria had obviously not been without its consequences." 
A personagem Maria nos parece uma nova versão do pensamento ocidentalista, mas termina seu sonho sendo abandonada pelo Ocidente; por outro lado, a sequência de seu sonho, exercida pelo protagonista do romance, extrapola a limitação de ser uma submissão à cultura ocidental e passa a ser quem fecunda seu “noivo". Schwarzenegger visto grávido por Piotr representa uma libertação à nova Rússia, tendo ela a possibilidade de influenciar culturalmente - e não mais ser vista apenas como receptáculo de valores impostos.

\section{Serdiuk e a identificação com o Oriente}

Quebrar com o paradigma da Rússia como país europeu parece ter sido um dos objetivos de Pelevin em A metralhadora de argila. Enquanto Maria "engravida" uma das figuras hollywoodianas mais marcantes do cinema do final do século XX com a libertação russa, outro detento da instituição psiquiátrica nos mostra uma realidade completamente diversa.

No sexto capítulo do romance, somos levados ao sonho de Serdiuk, que começa no metrô de Moscou (retomando o elemento do subterrâneo), mas desta vez o caminho é o oposto: se Maria apontava para o Oeste, esperando o noivo, Serdiuk sai da estação Dínamo em direção à Puchkinskaya. Se olharmos o mapa desse metrô, o trajeto é em direção ao Sudeste - geograficamente uma referência ao Japão, inclusive, país que será central para este sonho.

Vale ressaltar que enquanto Maria já se encontra na superfície da cidade, onde se dá o encontro com Schwarzenegger, sua ascensão é em direção ao céu; por outro lado, estando no subterrâneo, Serdiuk, que é a representação do Oriente, 
deve emergir para a superfície da mesma Moscou. Aqui parece-nos que Pelevin faz alusão ao fato de que a Rússia já, pelo menos superficialmente, se encontra na Europa, e que o lado oriental ainda está submerso.

Essa relação de contraposição é corroborada até pela extensão de cada capítulo, pois se o sonho de Maria compreende 17 páginas, o de Serdiuk 43, o que podemos entender como tanto uma maior proximidade e compreensão do conteúdo ocidental, mas também uma preocupação de Pelevin com a apresentação mais minuciosa do subterrâneo oriental. Não à toa, há muito mais verossimilhança no espaço moscovita descrito no sonho de Serdiuk e menos referências a ficção científica.

Antes de analisarmos a narrativa do sonho, a informação que justificará uma maior aproximação do Oriente por parte de Pelevin é a sua admiração pelo Budismo, do qual, mesmo não se declarando abertamente como budista, é praticante. Nas poucas entrevistas a que tivemos acesso ${ }^{31}$, o autor se declara como um estudante do Budismo, mas não um religioso, e sua prática contempla um interesse pessoal em atingir o "Darma" de Buda.

Portanto, estamos trabalhando com um autor que se identifica, ao menos espiritualmente, com o Oriente, mas que, conforme vimos no breve perfil que traçamos, também se interessa pela tecnologia da contemporaneidade, em especial se considerarmos a Internet como plataforma de divulgação dos seus trabalhos mais antigos. A dicotomia entre uma atualidade na escrita e práticas de uma religião de 2500 anos faz com que Pelevin promova uma complexidade ao romance nesses dois primeiros sonhos narrados.

31 As entrevistas estão disponíveis em: https://bombmagazine.org/articles/victor-pelevin/ https://www.nytimes.com/2000/01/23/magazine/gogol-a-go-go.html https://www.theguardian.com/books/2000/apr/30/fiction 
Logo de início nos deparamos com referências muito evidentes ao Japão: desde a saudação nazista (relembrando a aliança japonesa com os alemães e italianos na Segunda Guerra Mundial), o conteúdo do livro do vizinho de assento de Serdiuk (sobre militarismo japonês), até a dupla de conceitos "on" e "girl" (p. 152) imprescindíveis para o desenvolvimento do sonho, significando "débito de gratidão" e "obrigação e responsabilidade", respectivamente. Tais conceitos compõem a noção de dever no Japão, um código de comportamento que mais à frente será importante para o sonhador que acompanhamos.

Por sinal, mais uma vez o sonho é narrado em terceira pessoa - ou seja, pela percepção que Piotr tem da narrativa de Serdiuk. Desta maneira, nossa visão do contexto oriental será decorrente das sessões propostas por Timurovitch, e, ao reconsiderarmos que há um reconhecimento dos outros detentos em relação aos sonhos que acompanham, o conteúdo nipônico passará a ser compartilhado também com o protagonista.

Com isso em mente, podemos reconhecer uma voz de Pelevin em Serdiuk com a apresentação do Oriente no romance; por outro lado, também nos encontramos em Moscou. Assim, Serdiuk compra uma garrafa de vinho em um quiosque, com a intenção de relembrar sua infância, e, ao tomá-la, percebe que

O mundo tinha mudado completamente, e bem visivelmente - deixou de parecer hostil, e as pessoas passando por ele foram se transformando gradualmente de discípulos devotos do mal global em vítimas desse mal, apesar de não suspeitarem de que o eram. Depois de um ou dois minutos, algo aconteceu com o mal global em si - ou sumiu, ou simplesmente deixou de ser importante. [...] então o habitual lastro de devaneios bêbados o trouxeram de volta à realidade. 
Seus pensamentos voltaram ao livro que ele tinha lido no metrô. "Os japoneses," Serdiuk pensou, "eis uma grande nação! [...] Por que ninguém aqui vê nada além da América? Quão boa a América é para nós? É o Japão que deveríamos estar seguindo - nós somos vizinhos, não somos? É o desejo de Deus. E eles precisam de nossa amizade também - entre nós, nos livraríamos da América brevemente..." (PELEVIN: 1999, p. 155)

É evidente neste trecho a defesa da cultura oriental em relação à priorização feita de aproximação ao Ocidente. Serdiuk caminha, ao menos nesses pensamentos, na direção oposta a Maria, que abre os braços para o Oeste.

Toda essa cena ocorre enquanto Serdiuk está sentado num banco em uma praça, em frente a uma estátua de Aleksandr Puchkin (1799-1837), considerado o fundador da literatura russa moderna. Este poeta, por sua vez, é apresentado no romance por retomar a mesma discussão que já apresentamos sobre o período petrino, pois

Em seu relato de viagem de 1835, Puchkin destacou duas noções de identidade nacional russa. Por um lado, ele se referiu explicitamente ao Cáucaso e aos novos territórios conquistados como Rússia. Em outras palavras, ele retratou a Rússia como um império multinacional. Por outro lado, ele constantemente descrevia o Cáucaso como estrangeiro e exótico, e evidentemente parte do chamado Oriente. (JAHN: 2004, p. 55) ${ }^{33}$

Podemos perceber que tanto Serdiuk quanto Puchkin veem a presença do Oriente na Rússia - o primeiro, pela "fraternidade"; o segundo, pelo contexto étnico descendente das políticas imperialistas dos estadistas pós-Pedro I. A aparição de

32 No original em inglês: "The world was changed all right, and quite noticeably - it stopped feeling hostile, and the people walking past him were gradually transformed from devoted disciples of global evil into its victims, although they themselves had no inkling that was what they were. After another minute or two something happened to global evil itself - it either disappeared or simply stopped being important. [...] then the usual ballast of drunken thoughts dragged him back down into reality.

$[\ldots]$

His thoughts moved back to the book he had read in the metro. 'The Japanese,' Serdyuk thought, 'now there's a great nation! Why is it nobody here can see anything but America? What the hell good is America to us? It's Japan we should be following - we're neighbours, aren't we? It's the will of God. And they need to be friends with us too - between the two of us we'd polish off your America soon enough..."

33 No original em inglês: "In his travel account of 1835, Pushkin highlighted two notions of Russian national identity. On the one hand, he explicitly referred to the Caucasus and to the newly conquered territories as Russia. In other words, he depicted Russia as a multinational empire. On the other hand, he constantly described the Caucasus as foreign and exotic and clearly as a part of the so-called Orient." 
ambas as personagens (a ficcional e a histórica) nesse momento remetem à atualidade da discussão sobre a identidade russa em si.

Ao comprar outra garrafa de bebida e um hambúrguer para comer, Serdiuk retornou ao mesmo banco, mas o que ocorre em sequência evidencia o caminho que tomará o sonho. Abrindo a embalagem do lanche (uma folha de jornal), ele vê um anúncio de emprego da firma japonesa Taira Incorporated na filial de Moscou referência, inclusive, ao clã Taira de samurais, um dos mais fortes durante o período Heian no Japão, quando o Budismo estava no auge nesse país. A voz de Pelevin parece bem evidente nesta oportunidade que surge a Serdiuk.

Os devaneios alcoólicos, então, reaparecem quando ele percebe o anúncio, já que "notou com satisfação que os vários níveis de realidade estavam começando a se fundir" (p. 156) ${ }^{34}$, em mais uma alusão à união entre Oriente e Ocidente na Rússia. Essa fusão, aliás, se dá de maneira muito peculiar: o símbolo da firma possuía uma figura igual ao lado - um anel de cebola, um pedaço de carne do hambúrguer e uma mancha de ketchup.

A complexidade está não apenas na referência histórica japonesa, mas também em reconhecer que a fusão de realidades percebida por Serdiuk é também a proposta por Puchkin, apesar de menos sociológica do que a do poeta. A identidade nacional que o poeta relata integra tanto a ideia imperialista (seguindo a visão ocidental) quanto a noção de uma cultura oriental; Serdiuk vê a Rússia “ocupada" pela América, mas em seus pensamentos se aproxima do Japão.

Dando sequência ao momento na praça, Serdiuk acorda em sua casa sem lembrar de nada da noite anterior; ao se levantar, enquanto pensa em pegar uma

34 No original em inglês: "[...] noted with satisfaction that the various levels of reality were beginning to merge into each other [...]" 
cerveja na geladeira, toca o telefone. Acompanhamos a breve conversa com Oda Nobunaga (referência a um dos grandes senhores feudais da história do Japão), que relembra uma conversa na última noite sobre uma proposta de trabalho - oriunda do anúncio visto no jornal.

É interessante perceber a geografia do trajeto que Serdiuk fará até a sede da Taira: inicialmente nos deslocamos da estação Dínamo à Puchkinskaia, enquanto o endereço que Nobunaga dita a Serdiuk é na estação Nagornaia - que está a sudeste da Puchkinskaia. A jornada do protagonista do sonho segue um caminho que pode remeter ao que seria uma viagem de Moscou ao Japão.

Na descrição do entorno da estação Nagornaya, Pelevin nos apresenta mais uma divisão de seu país entre o mundo europeu e o asiático:

Era um lugar selvagem, como os restos de uma região industrial que fora bombardeada aos pedaços num passado distante, agora ocupada por capim pelo qual, aqui e ali, se projetavam pedaços de ferro enferrujado. Havia bastante espaço aberto e céu, e ele podia ver faixas escuras de floresta no horizonte. Apesar dessas trivialidades, essa região era muito incomum: se ele olhasse para o Oeste, onde estava a cerca verde, ele via uma paisagem urbana comum, mas se ele se voltasse para o Leste, seu campo de visão era inteiramente preenchido por uma grande extensão de vazio, com alguns postes de luz como se fossem árvores de forca. Era como se Serdiuk tivesse encontrado seu caminho precisamente à fronteira secreta entre a Rússia pós-industrial e a Rus' primordial. (PELEVIN: 1999, p.158) $)^{35}$

Com isso, podemos retomar a noção de Rússia predominante após as propostas

petrinas: de um país europeu, identificado com o urbanismo e o progresso científico.

Em contrapartida, o Oriente (lembrando que Moscou está a Sudeste de São

Petersburgo) é descrito como uma região vasta e cheia de vazio.

35 No original em inglês: "It was a wild place, like the remnants of some industrial region bombed to smithereens in the distant past and now overgrown with wild grass, through which, here and there, pieces of rusty iron protruded. There was plenty of open space and sky, and he could see dark strips of forest on the horizon. But despite these banal commonplaces, this region was very unusual: if he looked to the west, where the green fence was, he saw a normal panoramic cityscape, but if he turned his gaze to the east, his field of view was entirely filled with a vast stretch of emptiness, with a few street lamps towering above it like gallows trees. It was as though Serdyuk had found his way precisely to the secret border between post-industrial Russia and primordial Rus." 
A visão de uma Rússia rumando para o Oeste e com um Leste esvaziado corrobora nossa impressão de que Pelevin reconhece um afastamento de seu país em relação ao Oriente, cada vez mais se abrindo à cultura ocidental. Mais do que isso, o progresso é visivelmente citado pelo contexto pós-industrial versus uma Rus' primordial - e isso nos surge de maneira interessante: em uma "fronteira secreta".

Novamente há a principal dualidade cultural observada por Lotman e Uspensky, trabalhada por Pelevin numa construção espacial que contrapõe cidade e vazio; progresso técnico e cultura primordial; Oeste e Leste. Mais adiante, então, o que era apenas representado espacialmente é personificado em

[...] japoneses que fracassaram ao se ajustar às demandas do mundo que se transformava [...]. Agora estava evidente por que tinham se interessado pela sua ligação bêbado, e Serdiuk até sentiu um surto de simpatia e calorosa compaixão por aqueles estrangeiros levemente estúpidos que, tal como ele, não foram capazes de encontrar uma colocação confortável para si mesmos na vida [...] (PELEVIN: 1999, p. 158)

Serdiuk se solidariza com os japoneses - ou, indiretamente, com o oriental na Rússia - por, ao reconhecer o Japão como "vizinho", pensar que sua situação é semelhante à deles. A dificuldade de adaptação com o novo mundo russo, póssoviético, aproxima Serdiuk dessa orientalidade que, conforme Pelevin, está se tornando um "espaço vazio".

Mais evidente ainda do que a aproximação com o Japão, Serdiuk nos traz à tona a dificuldade de adaptação ao relembrarmos que é um detento em uma instituição psiquiátrica. Não há uma "colocação confortável” a essa personagem, mas uma necessidade de tratamento que o adéque às mudanças da Rússia em transformação.

36 No original em inglês: "[...] Japanese who had failed to adjust fully to the demands of the changing world [...]. It was clear now why they'd taken such an interest in his drunken phone call, and Serdyuk even felt a surge of sympathy and warm fellow-feeling for these slightly dull-witted foreigners who, just like himself, had not been able to find themselves a comfortable niche in life $[\ldots] "$ 
Por outro lado, a história cultural que vimos de europeização em detrimento da aproximação com os "orientais" é mostrada quando Serdiuk entra na casa onde fará a entrevista: o segurança indica o caminho e um lampião para que siga por um corredor. Ao questionar sobre o lampião, Serdiuk recebe como resposta: “É a regra aqui,' disse o segurança, pegando um dos lampiões da parede e dando-o para Serdiuk, 'você não veste uma gravata para se manter aquecido, veste?'” (p. 160) ${ }^{37}$. A gravata é a contraposição ao lampião, numa óbvia comparação cultural.

Parece-nos que o embate entre Rússia $\leftrightarrow$ Ocidente, proposto por Lotman e Uspensky, se transformou em Rússia $\leftrightarrow$ Oriente, mas o que Pelevin nos apresenta, principalmente por meio de Serdiuk, é uma artificialidade na contrapartida entre as culturas. Os costumes de Serdiuk se aproximam do que foi proposto no período petrino; em contrapartida, suas ambições são voltadas ao Oriente.

O uso de nomes expressivos para delimitar as divisões do romance não será deixada de lado no sonho de Serdiuk, tendo em vista que seu futuro chefe tem o nome de Kawabata. Esta referência é ao autor Yasunari Kawabata (1899-1972), escritor japonês vencedor do Prêmio Nobel de Literatura em 1968, e tal escolha foi feita porque Kawabata representa a maior voz em defesa do Orientalismo, corrente de pensamento que entende que o contato com o Ocidente fez os países orientais perderem o contato com suas raízes.

A contraposição entre a aproximação à racionalidade ocidental e um pensamento orientalista fica ainda mais evidente na própria entrevista:

"Eu fico frequentemente horrificado por observar," ele disse, "que metade da Rússia já foi infectada com o repulsivo pragmatismo do Ocidente. Exceto a companhia presente, claro, mas eu tenho uma boa razão para o dizer." "Mas o que há de errado com o pragmatismo?" perguntou Serdiuk.

"Em tempos antigos," disse Kawabata, "em nosso país, oficiais eram

37 No original em inglês: "That's the rule here,' said the security guard, taking one of the lanterns down from the wall and holding it out to Serdyuk, 'you don't wear a tie to keep you warm, do you?" 
selecionados para cargos importantes depois de exames nos quais eles escreviam um ensaio sobre o belo. E esse era um princípio sábio, pois se um homem possui um entendimento sobre o que é imensuravelmente maior do que procedimentos burocráticos, então ele certamente será capaz de lidar com tais assuntos inferiores. [...]" (PELEVIN: 1999, p. 164)

Tal discurso remete ao embate histórico da cultura russa entre uma razão ocidental e uma espiritualidade oriental. Isso é muito evidente, como vimos, no cisma do cristianismo, por exemplo, entre Roma e Bizâncio - a segunda sendo a vertente que a Rússia seguiu.

A racionalidade é o ponto mais criticado por Kawabata, coerente com o autor referenciado, e justamente porque passa a ser valorizada na Rússia em detrimento da noção do artístico e espiritual. Por um lado, a empresa que nos é apresentada é de comércio, trazendo a Serdiuk números, compras e vendas, lucros e dividendos; por outro, ele só consegue o emprego ao analisar uma imagem de um artista japonês. O empregado só está apto a exercer o cargo se tiver condições de olhar "além" da figura.

Transcender à realidade é de suma importância para trabalhar nessa empresa porque, mesmo estando localizada na Rússia, ela representa um lado de oposição à cultura dominante ocidental entrando no país eslavo. Esse diálogo entre Serdiuk e Kawabata, aliás, possui trechos interessantes da relação que a Taira Inc. pretende estabelecer ali.

"Provavelmente," ele disse, estendendo seu copo vazio para Kawabata, "a razão pela qual isso acontece é porque, por natureza, o russo não é inclinado a buscar um sentido metafísico e se vira com um coquetel de ateísmo e alcoolismo o qual, verdade seja dita, é nossa maior tradição espiritual."

38 No original em inglês: 'I am frequently horrified to observe,' he said, 'that half of Russia has already been infected with the repulsive pragmatism of the West. Present company excepted, of course, but I have good reason for saying so.'

'But what's wrong with pragmatism?' asked Serdyuk.

'In ancient times,' said Kawabata, 'in our country officials were appointed to important posts after examinations in which they wrote an essay on beauty. And this was a very wise principle, for if a man has an understanding of that which is immeasurably higher than bureaucratic procedures, then he will certainly be able to cope with such lower matters. [...]" 
Kawabata serviu novamente para si e para Serdiuk.

"Nesse ponto eu devo tomar a liberdade de discordar de você," ele disse. [...]

"Esse também é um dos princípios da nossa firma. Nós sempre tentamos penetrar na alma interna de qualquer nação com quem fazemos negócio. Não é uma questão de desejar extrair nenhum lucro adicional ao entender... Qual a palavra em russo? Mentalidade, certo?"

Serdiuk assentiu.

"Não," Kawabata continuou, abrindo um grande arquivo. "É mais uma questão de desejo de elevar ao nível da arte até aquelas atividades que estão mais afastadas dela. [...]" (PELEVIN: 1999, p. 165-166) ${ }^{39}$

Ou seja, o interesse do Oriente na Rússia não é apenas a obtenção de bons negócios no sentido monetário, mas poder entender profundamente seus novos parceiros. Esse trecho nos mostra, sobretudo, que Pelevin vê a ligação que o russo tem com o oriental como algo relacionado muito mais à mente e ao espírito do que ao comportamento social (expresso também na gravata de Serdiuk, por exemplo; ou nos elementos já citados do sonho de Maria).

Muito do que aparece nas discussões é ligado à imagem que já vimos da emergência de fatores culturais - desde o voo com Schwarzenegger até a saída do metrô. A oposição é muito evidente nos elementos que levarão à elevação: no caso do sonho de Maria, há um jato, o metal e a ação hollywoodiana; Serdiuk, por sua vez, se elevará (até socialmente, com um novo emprego) por conta da interpretação artística. A materialidade versus a espiritualidade é o embate representado pelo Ocidente versus Oriente.

Um retorno à imagem que fora a prova para a contratação nos leva, ainda

39 No original em inglês: "'Probably,' he said, holding out his empty glass to Kawabata, 'the reason it happens is that by nature the Russian is not inclined to a search for metaphysical meaning and makes do with a cocktail of atheism and alcoholism which, if the truth be told, is our major spiritual tradition.'

Kawabata poured again for himself and Serdyuk.

'On this point I must take the liberty of disagreeing with you,' he said. [...]

'That is also one of our firm's principles. We always attempt to penetrate the inner soul of any nation with whom we do business. It is not a matter of wishing to extract any additional profit in this way by understanding the... What is the Russian word? Mentality, isn't it?'

Serdyuk nodded.

'No,' Kawabata continued, opening a large file. 'It's more a matter of a desire to raise the level of art even those activities that are furthest removed from it. [...]" 
mais evidentemente, ao cerne da questão levantada por Pelevin:

\begin{abstract}
"Agora dê mais uma olhada à imagem na parede," ele disse.
"Sim," disse Serdiuk.

"Você vê como é construída? O segmento de realidade em que on e giri estão contidos é localizado bem no centro, e tudo ao redor é um vazio, do qual isso aparece e ao qual desaparece. No Japão nós não atormentamos o Universo com pensamentos desnecessários sobre sua causa e origem. Nós não carregamos Deus com o conceito de 'Deus'. No entanto, o vazio desta imagem é o mesmo vazio que você vê no ícone de Burliuk. Uma coincidência muito significativa, não é?"

"Claro," disse Serdiuk, estendendo seu copo vazio para Kawabata.

"Mas você não encontra esse vazio na pintura religiosa ocidental," Kawabata disse enquanto servia. "Tudo lá é preenchido com objetos materiais - todo tipo de cortinas e dobras e taças de sangue e Deus sabe o que mais. A visão única de realidade refletida nestes dois trabalhos de arte é comum apenas para você e para nós, e portanto eu acredito que o que a Rússia precisa é de um casamento alquímico com o Oriente."

"Eu juro por Deus," disse Serdiuk, "ontem à tarde mesmo eu estava..."

"Precisamente com o Oriente," interrompeu Kawabata, "e não o Ocidente. Você entende? Nas profundezas da alma russa existe o mesmo vazio que encontramos profundamente na alma do Japão. E desse mesmo vazio o mundo vem a existir, constantemente, a cada segundo. Saúde." (PELEVIN: 1999 , p. 169$)^{40}$
\end{abstract}

Se Maria procurava um casamento com o noivo vindo do Ocidente, Serdiuk olha para o outro lado do mundo, numa aproximação com o lado oriental russo.

Apesar dos esforços históricos de aproximação com o Ocidente, essa proximidade com o Oriente não é nova nem indissociável da formação da Rússia,

afinal

Considerando sua nação europeia, eles acreditaram que ela deveria ser mais como os vizinhos ocidentais. O sentimento predominante de que tal caminho era vital para a sobrevivência da nação permitiu ao novo czar,

40 No original em inglês: '"Now take another look at the print on the wall,' he said.

'Yes,' said Serdyuk.

'Do you see how it is constructed? The segment of reality in which the on and the giri are contained is located in the very centre, and all around it is a void, from which it appears and into which it disappears. In Japan we do not torment the Universe with unnecessary thoughts about its cause and origin. We do not burden God with the concept of "God". But nonetheless, the void in this print is the same void as you see in Burliuk's icon. A truly significant coincidence, is it not?'

'Of course,' said Serdyuk, holding his empty glass to Kawabata.

'But you will not find this void in Western religious painting,' Kawabata said as he poured. 'Everything there is filled up with material objects - all kind of curtains and folds and bowls of blood and God only knows what else. The unique vision of reality reflected in these two works of art is common to only you and us, and therefore I believe what Russia really needs is alchemical wedlock with the East.'

'I swear to God,' said Serdyuk, 'only yesterday evening I was...'

'Precisely with the East,' interrupted Kawabata, 'and not the West. You understand? In the depths of the Russian soul lies the same gaping void we find deep in the soul of Japan. And from this very void the world comes into being, constantly, with every second. Cheers."” 
Alexandre II, introduzir reformas radicais que ajudaram a remodelar a ordem cívica segundo linhas mais ocidentais. Mas para outros, o constante declínio de São Petersburgo em relação a grandes poderes da Europa durante a segunda metade do século XIX fez da Ásia mais atraente. O tenentegeneral Blaramberg falou por muitos quando proclamou que "o futuro da Rússia não está na Europa: ele deve olhar para o Leste." Alguns viam o Oriente como uma arena para glória marcial. Provado no Oriente Próximo pela Guerra da Crimeia e novamente no Congresso de Berlim duas décadas depois, eles viram a expansão para a Ásia Central e o Oriente Distante como um estimulante para o orgulho ferido de seu império. Um grupo menor, e, no entanto, influente, começou a argumentar que o destino da Rússia se encontrava no Leste porque ela era mais Asiática do que Europeia. (VAN DER OYE: 2010, p. 225-226) ${ }^{41}$

Num momento em que se desenhava uma Rússia europeizada, a aproximação com o Oriente se fazia evidente, numa cisão que já visitamos neste estudo, e que pressupunha caminhos distintos para a cultura russa.

Serdiuk, por sua vez, tem muito da voz budista de Pelevin, de um apreço por aquilo que há de espiritual no Oriente e que é esquecido pelo Ocidente. Apesar de, neste recorte que fizemos, parte da visão ser por um sentimento de superioridade bélica e necessidade de conquista da Ásia, vemos que há uma ideia de pertença até mesmo no uso do conceito de destino.

Se retomarmos as impressões de Kawabata, fica muito óbvio que há uma relação intrínseca entre os "vazios interiores" russo e japonês, e, mais do que a visão de destino, o que mais une Rússia e Japão é um compartilhamento espiritual. Afinal, no século XIX a corrente do Asianismo pregava que a Rússia era "mais misticismo oriental e menos razão iluminista europeia”.

Assim, podemos reconhecer que

41 No original em inglês: "Considering their nation to be European, they believed that it had to be more like its occidental neighbours. The prevailing sentiment that such a course was vital to national survival enabled the new tsar, Alexander II, to introduce sweeping reforms that helped reshape the civic order along more occidental lines. But for others, St Petersburg's steady decline among Europe's great powers during the nineteenth century's second half made Asia all the more appealing. Lieutenant-General Blaramberg spoke for many when he proclaimed, 'Russia's future does not lie in Europe: it must look to the East.' Some turned to the Orient as an arena for martial glory. Checked in the Near East by the Crimean War and again at the Congress of Berlin two decades later, they saw expansion into Central Asia and the Far East as a tonic for their empire's wounded pride. A smaller but nonetheless influential group began to argue that Russia's destiny lay in the East because it was essentially more Asian than European itself." 
"O Oeste", ele escreveu, "é vagamente refletido em nossa vida intelectual. Os abismos por baixo da superfície têm sua existência em uma atmosfera de visões e crenças profundamente orientais." Como os asiáticos, os russos contam mais com a fé do que com a razão. Como Ukhtomsky explicou: "Nós sentimos nosso isolamento espiritual e político dos países romanogermânicos sobrecarregados por uma civilização muito exigente. Para nós ... [como para] a Ásia, a base da vida é a crença religiosa." Ao mesmo tempo, tanto russos quanto asiáticos rejeitavam o materialismo. Mas acima de tudo, ambos eram ligados por uma ânsia pela mão firme e paternal do governante: "O Leste crê tanto quanto nós ... [na] nossa mais preciosa tradição nacional - autocracia. (VAN DER OYE: 2010, p. 230) ) $^{42}$

Não apenas há um elo espiritual, mas a política de repressão, presença recorrente no panorama histórico, também é compartilhada com o Oriente. Mais adiante no romance isso surgirá para Serdiuk também.

Antes disso, ambos saem numa caminhada para comprar mais bebida - uma continuação dos devaneios alcoolizados do início do sonho, intensificada pela visão de Serdiuk sobre a "tradição espiritual russa" -, algo acompanhado por delírios de ambos com elementos de tradição japonesa. A união, então, se dá com o suporte russo, mas as imagens são nipônicas, no que podemos depreender como uma transcendência espiritual coletiva dual, ocorrendo no espaço russo e almejando o Oriente.

Ao voltarem da caminhada, Kawabata "oferece" uma orgia a Serdiuk, sob a justificativa de que o sexo é "um dos poucos sentimentos naturais que um homem ainda pode experimentar" (p. 177) ${ }^{43}$. A imagem sexual deste sonho é tratada como natural, em contrapartida à artificialidade e o maquinário do sonho de Maria, apesar de ambos os sonhos tratarem essa relação como o "casamento alquímico" com o

42 No original em inglês: "The West', he wrote, 'is but dimly reflected in our intellectual life. The depths below the surface have their being in an atmosphere of deeply oriental views and beliefs.' Like Asians, Russians relied more on faith than on reason. As Ukhtomsky explained: 'We feel our spiritual and political isolation from the Romano-Germanic countries overburdened by a tooexacting civilization. Fur us ... [as] for Asia, the basis of life is religious belief.' At the same time, both Russians and Asians were repelled by materialism. But above all, the two were bound by a yearning for the rule's firm, paternal hand: 'The East believes no less than we do ... [in] the most precious of our national traditions - autocracy." (Grifos no original)

43 No original em inglês: "[...] is one of the few remaining natural feelings which a man may still experience." 
respectivo ideal.

É justamente ao fazer tal oferta que Kawabata faz o que reconhecemos como uma das mais importantes afirmações do romance:

"[...] mas não há nada que acontece em nações e países que não é repetido de forma simbólica na vida dos indivíduos que vivem nesses países e compõem essas nações. A Rússia, em última análise, é você. Então, se você falou sinceramente, e é claro que não posso pensar de outra maneira, vamos realizar esse ritual imediatamente. Vamos, por assim dizer, consolidar nossas palavras e nossos pensamentos com uma fusão simbólica de princípios básicos..." (PELEVIN: 1999, p. 177)

A realização do ato sexual, no sonho de Serdiuk, é uma forma de fusão espiritual das palavras e pensamentos, mais do que uma cópula propriamente dita, de início. Isso fica muito evidente se compararmos a descrição de todo o sexo de Maria com Schwarzenegger em contraposição ao salto que Pelevin dá, não detalhando nada da orgia.

Ainda mais interessante do que essa diferença na abordagem ao sexo, a frase "a Rússia, em última análise, é você" possui uma importância indiscutível para este estudo. O romance apresenta-nos um grupo de detentos numa instituição psiquiátrica, em tratamento para tentar se recuperar de uma cisão psicológica; o que Kawabata disse é uma pista valiosa para que entendamos a visão de Pelevin sobre seu país: uma Rússia esquizofrênica.

O compartilhamento da experiência sexual, no entanto, não é o mesmo de Maria, que é passiva em relação a Schwarzenegger e depois é arremessada do jato ao se recusar a seguir os pedidos dele. Kawabata e Serdiuk não têm relações entre si (ou, pelo menos, somos levados a crê-lo, pois Serdiuk, ao entender a sugestão de Kawabata, teme que este seja homossexual), mas ainda assim estão juntos na

44 No original em inglês: "[...] but there is nothing that happens to nations and countries that is not repeated in symbolic form in the life of the individuals who live in those countries and make up those nations. Russia, in the final analysis, is you. So if you spoke sincerely, and of course I cannot at all believe otherwise, then let us perform this ritual immediately. Let us, as it were, reinforce our words and thoughts with a symbolic fusion of basic principles..." 
orgia.

De certa maneira, parece que o Ocidente apenas se aproveita da Rússia de uma maneira mais explícita, no entanto sem diálogos e conexões profundas; por outro lado, o Oriente compartilha as experiências com a Rússia "pessoalmente", mas com mais "pudor". Com esta contraposição, fica muito evidente a ideia da superficialidade da relação com o Ocidente e do Oriente como figura do subterrâneo russo.

Neste mesmo subterrâneo, conforme vimos, está a figura da repressão do governante, que surgirá de modo óbvio quando forem discutidas as condições do contrato de trabalho de Serdiuk:

"Como já mencionei que nossa firma é, na verdade, mais parecida com um clã, segue-se que nossos empregados são como membros de um clã. E as obrigações que eles têm sobre si também são diferentes das obrigações usuais que trabalhadores aceitam. Para simplificar, nós te aceitamos como um membro do nosso clã, que é um dos mais antigos do Japão. [...] É um cargo para um samurai, e um leigo não pode ocupá-lo. Portanto, se você está disposto a aceitar o cargo, eu te farei um samurai."

$[\ldots]$

"Como eu esperava. Agora me diga, você está pronto para aceitar que é um samurai do clã Taira?"

"Devo dizer que sim."

"Você está pronto para ligar sua vida e sua morte ao destino do clã?"

Todos esses rituais loucos que eles têm, pensou Serdiuk. Onde eles arranjam tempo para fazer todas aquelas televisões?

"Eu estou," ele disse.

"Você estará preparado, como um homem de verdade, para atirar a flor efêmera que é esta vida sobre a beira do abismo em direção ao vazio, se isso for exigido de você por seu giri?" Kawabata perguntou com um aceno em direção à imagem na parede.

Serdiuk a olhou novamente.

"Estarei," ele disse, "com certeza. Arremessar a flor no abismo - sem problema."

"Você jura?"

"Eu juro."

"Esplêndido," disse Kawabata, "esplêndido. Agora há apenas uma pequena formalidade faltando, e então teremos terminado. Devemos receber confirmação do Japão. Mas isso levará apenas alguns minutos." (PELEVIN: 1999 , p. $181-182)^{45}$

45 No original em inglês: "Since I have already mentioned that our firm is in reality more like a clan, it follows that our employees are more like members of a clan. And the obligations which they take upon themselves are also different from the usual obligations that hired hands accept. To put it simply, we accept you as a member of our clan, which is one of the most ancient in Japan. [...] This is a post for a samurai, and a layman may not occupy it. Therefore, if you are willing to accept the post, I will make you a samurai.' 
Esta longa exposição de Kawabata sobre a vaga de emprego nos leva de volta às referências que já citamos à tradição japonesa, à história do país e ao poder que o clã Taira teve no passado. Também corrobora a submissão que Serdiuk deve acatar: dedicar e oferecer a própria vida à firma ao aceitar seu giri, ou seja, só será um samurai por "obrigação e responsabilidade".

A confirmação vinda do Japão, por sua vez, é mais um elemento que retoma a ideia de um simbolismo oriental que se contrapõe à materialidade do Ocidente: Kawabata desenha um crisântemo, a flor que representará a vida de Serdiuk enviada - via fax - para a sede do clã. Em resposta, a aceitação se dá pela recepção, por fax também, de um desenho de uma espada, o qual é dado ao novo empregado como símbolo de seu novo status.

Não muito depois da admissão temos a confirmação do poder de uma entidade superior, quando a notícia da aquisição de ações da Taira Inc. por um clã rival - Minamoto Group, fazendo referência a outro clã samurai do mesmo período do Taira - chega a Kawabata. O sentimento de desonra que acomete a empresa se refletirá nos empregados, que, assim, devem deixar suas vidas para que Minamoto não possa se vangloriar da conquista sobre o clã de Serdiuk.

\footnotetext{
$[\ldots]$

'As I expected. Now tell me, are you ready to accept that you are a samurai of the Taira clan?'

'I should say so.'

'Are you willing to link your life and your death with the destiny of our clan?'

All these crazy rituals they have, thought Serdyuk. Where do they find the time to make all those televisions?

'I am,' he said.

'Will you be prepared, as a real man, to cast the ephemeral blossom of this life over the edge of the abyss and into the void if this is required of you by your giri?' Kawabata asked with a nod in the direction of the print on the wall.

Serdyuk took another look at it.

'I will,' he said, 'of course. Chuck the blossom down the abyss - no problem.'

'You swear?'

'I swear.'

'Splendid,' said Kawabata, 'splendid. Now there is only one small formality left, and we'll be finished. We must receive confirmation from Japan. But that will only take a few minutes."'
} 
A morte forçada não parece tão imediata ao acompanharmos Serdiuk numa tentativa de fuga da empresa, mas ele é barrado pelo segurança, o qual, fazendo parte das forças de segurança do Japão, é treinado inclusive para responder aos questionamentos metafísicos de Serdiuk. Ao retornar ao escritório de Kawabata, a questão da tradição - que inclui o seppuku, suicídio com a introdução de uma espada nas entranhas, seguida por uma decapitação, e realizado historicamente pelos samurais desonrados - reaparece, agora com uma vergonha ainda maior de Kawabata por não pensar em quem cortaria a cabeça de seu novo empregado.

A doutrina do seppuku, inclusive, é mais uma referência à espiritualidade japonesa, pois representa "a doutrina do retorno direto e destemido à eternidade" (p. 190 $)^{46}$. Quando Kawabata termina de explicar os diferentes tipos de incisão da espada, Serdiuk tenta se levantar, mas é forçado a se manter de joelhos pela mesma imagem da repressão: uma mão nos ombros, tal qual a firme e paternal mão do governante sobre os povos asiáticos. Japão e Rússia, aqui, estão compartilhando até o momento da morte.

Por outro lado, enquanto comete o seppuku, Serdiuk vê Kawabata atender o telefone e entrar em uma ríspida discussão sobre a venda de um carro. Nesse momento, inclusive, há uma informação que parece banal: o modelo do veículo é do ano de 1996, enquanto o romance se passa em 1991. Serdiuk não apenas transita pelo passado com as tradições japonesas, mas inclui em seu sonho o futuro - que acompanha a sua morte.

Isso nos lembra da teoria de que o destino da Rússia é o Oriente, mas há também a presença da morte nesse futuro. A visão da morte, em contrapartida, é a de um retorno à eternidade, e vista como libertação num momento de desonra, 
denotando uma libertação. Serdiuk enquanto Rússia e Kawabata enquanto Japão se unem, finalmente, rumo àquele vazio gerado pelo giri.

Serdiuk o atinge antes, sob a discussão de Kawabata, mas produzindo uma das mais profundas teorias presentes no romance:

\begin{abstract}
Serdiuk percebeu que o espaço em que o telefone tocou e Kawabata estava xingando e tudo mais estava acontecendo era um lugar muito longe dele; era um segmento muito insignificante de realidade que ele precisou focar com toda sua força para acompanhar o que acontecia lá. Ao mesmo tempo, não havia absolutamente nenhum sentido nesse ato de concentração: Serdiuk percebeu que essa concentração era a vida. Acontece que toda sua longa existência como ser humano, com todos seus anseios, esperanças e medos, não havia sido nada além de um pensamento efêmero que momentaneamente tomara sua atenção. E agora Serdiuk - embora não fosse realmente Serdiuk - estava à deriva por um vazio inqualificável, e ele sentiu que estava chegando perto de algo enorme que irradiava um calor intolerável. [...] A sensação era insuportável, e Serdiuk começou a buscar febrilmente pelo lugar onde ele havia deixado o antigo mundo que lhe era familiar. (PELEVIN: 1999, p. 195) ${ }^{47}$
\end{abstract}

Este trecho corresponde ao final do sonho de Serdiuk, do qual ele acorda apenas ao morrer. Atingir a eternidade significou um desligamento da realidade material em que existia com Kawabata, numa evidente ligação com o nirvana budista.

Só foi possível atingir esse estado por meio do alcoolismo, o qual permitiu a Serdiuk realizar a entrevista (depois de um contato do qual ele não se lembra) e permeou todo o contato com Kawabata. A soma do álcool ao "recrutamento" da Rússia ao Oriente levou Serdiuk a esse nirvana, momento máximo da espiritualidade budista.

Quando voltamos ao hospício, Piotr promove a ideia do vazio dizendo que por

47 No original em inglês: "Serdyuk noticed that the space in which the telephone was ringing and Kawabata was swearing and everything else was happening was somewhere very far away from him; it was such an insignificant segment of reality that he had to focus with all his strength to follow what was going on there. At the same time, there was absolutely no sense in this act of concentration: Serdyuk realized that this concentration was life. It turned out that his entire, long existence as a human being, with all its longings, hopes and fears, had been nothing more than a fleeting thought that had momentarily attracted his attention. And now Serdyuk - although it was not really Serdyuk at all - was drifting through a qualityless void and he sensed he was coming close to something huge that radiated an intolerable heat. [...] The sensation was quite unbearable, and Serdyuk began feverishly searching for the spot where he had left behind the old, familiar world." 
um longo tempo não houve absolutamente nada. $\mathrm{O}$ desligamento da realidade causado pelo nirvana é tal que, conforme Piotr descreve, o tempo decorrido entre o final do sonho e a primeira reação sequer existe. Lembremos que, além de haver o compartilhamento da realidade sonhada com os outros pacientes, o romance é narrado em primeira pessoa. Piotr participou dessa aproximação com o Oriente, atingiu a morte e, com isso, o vazio.

A interrupção do vazio se dá com Timurovitch, que explica como Serdiuk fora encontrado antes de ser internado: com a cabeça apoiada num aquecedor e uma garrafa quebrada em sua mão. Justifica-se, assim, a imagem final do seppuku de Serdiuk, ligada explicitamente ao alcoolismo - figura recorrente, conforme vimos, em todo o sonho.

Por fim, alcançamos a segunda vertente cultural histórica russa, com a contraposição que Serdiuk representa a Maria. O Ocidente de Schwarzenegger, da superfície, que carrega Maria pela materialidade num voo do qual ela será arremessada de volta a Moscou versus o Oriente com Kawabata, do subterrâneo, regado pelo alcoolismo e representante da espiritualidade que levará à morte - e, enfim, à eternidade.

\section{Volodin: metafísica da identidade}

Até o momento analisamos dois sonhos que nos mostraram de maneira mais evidente a aproximação da Rússia tanto com Ocidente (Maria) quanto com o Oriente (Serdiuk). As referências, até agora óbvias pelas relações estabelecidas com Schwarzenegger e Kawabata, nos permitiram estabelecer as personagens como 
representantes de duas vertentes culturais russas, cada uma com valores conflitantes, mas que compõem os alicerces do país.

Volodin, por outro lado, apresenta um sonho muito mais metafísico do que os outros companheiros de instituição. Em conformidade com nossas observações, há uma ascensão em relação à superfície ocidental e uma saída do subterrâneo oriental, sobretudo pela contextualização espiritual - sobretudo pelos valores samurais e budistas. Volodin, contrapondo esses relacionamentos muito bem definidos durante os sonhos de Maria e Serdiuk, é o que trabalha com uma realidade mais complexa e, ao mesmo tempo, espacialmente menos elaborada.

Durante o romance, Volodin é o detento que mais frequentemente dialoga com Timurovitch, dando a impressão de exercer uma espécie de liderança entre seus colegas. Por outro lado, seus discursos são sempre carregados com uma ironia em relação às condições psiquiátricas dos outros - entre as observações há, inclusive, o comentário de que todos os samurais do clã Taira eram espíritos que buscavam os talentos de nosso mundo para si (p. 195-196).

O hiato entre o sexto capítulo, que contém o sonho de Serdiuk, e o oitavo, de Volodin, é, na verdade, um dos mais importantes para o autorreconhecimento de Piotr, já numa espécie de "final de tratamento" no romance. Isso tem importância porque percebermos que, após passar pela vivência com os mundos ocidental e oriental, Piotr já começa a se identificar no mundo, embora não totalmente: isso só estará completo após acompanhar a realidade metafísica de Volodin.

Então, no início do capítulo do sonho desta personagem, o diálogo com o psiquiatra é esclarecedor porque, à pergunta sobre a ideia de que o clã Taira era composto de espíritos, há a resposta:

"Eu não sei," ele disse. "Você me perguntou o que eu estava pensando 
naquele exato momento. Bem, eu estava pensando que se houvesse algum observador externo por lá para assistir, ele provavelmente pensaria que não éramos reais, que não éramos nada além de sombras tremulantes e reflexos das chamas - eu te disse que havia uma fogueira. Mas você sabe, Timur Timurovitch, tudo realmente depende do observador..." (PELEVIN: 1999 , p. 240$)^{48}$

Volodin não acompanha a realidade física que é apresentada - e a qual acompanha durante as sessões -, mas a observa "de fora". A interpretação que esta personagem nos dá é a de um narrador exegético, tal qual Piotr nos aparece durante os sonhos de seus companheiros.

Depender do observador é o que nos carrega direto ao sonho de Volodin, numa imagem de uma fogueira iluminando figuras que eram como sombras espectrais (p. 240). Mais notável do que essa comparação das personagens do sonho é o momento em que se cita: "desde que o último dos neoplatônicos abandonou sua vergonha ao possuir um corpo logo antes do Vigésimo Congresso do Partido Comunista da União Soviética" (p. 240) ${ }^{49}$ não houve decisão alguma que afetasse muita coisa - o que tem um efeito político extremamente marcante, pois é neste episódio do congresso que há uma crítica (ainda que velada) ao regime de Josef Vissariónovitch Stalin (1878-1953), sobretudo na condenação ao culto à personalidade.

Enquanto essas sombras tremulavam ao redor da fogueira, o que se destacava eram um carro da Toyota (referência ao Oriente) com um guincho em seu capô, que Volodin descreve como um item inútil na vida normal (na superfície do carro, e este aspecto superficial nos remete à crítica ao Ocidente). Ou seja, não nos

48 No original em inglês: "I don't know,' he said. 'You asked me what I was thinking just at that moment. Well, I was thinking that if there was any external observer around there to watch, he's probably have thought we weren't real, that we were nothing but flickering shadows and reflections from the flames - I told you there was a camp-fire. But then you know, Timur Timurovich, it all really depends on the observer..."

49 No original em inglês: "[...] since the last of the local neo-Platonists had abandoned his shame at possessing a body shortly before the Twentieth Party Congress [...]" 
é apresentada uma contraposição aos outros dois sonhos, mas surgem elementos que retomam os outros dois momentos oníricos do romance.

A este destaque segue uma análise presumidamente sociológica de Volodin sobre

(Antropólogos que dedicaram seus esforços estudando os "novos russos" acreditam que esses guinchos são usados como aríetes durante represálias, e alguns estudiosos, inclusive, veem sua popularidade como um indício indireto do muito esperado ressurgimento do espírito da nação - eles acreditam que os guinchos preenchem o papel místico das figuras importantes que ornamentavam a proa dos antigos barcos eslavos.) (PELEVIN: 1999, p. 241) $)^{50}$

Assumir elementos superficiais, tais quais os guinchos no capô de carros japoneses, como parte da cultura dos "novos russos" significa classificar esses mesmos russos no âmbito da superficialidade. Apesar de haver o fator oriental no Toyota, até ele é sobreposto pelo guincho ocidental.

Este é o segundo momento em que nos deparamos com o conceito de "novo russo", o que também nos remete ao raciocínio de Lotman e Uspensky:

O século XVIII surgiu sob a bandeira da inovação. O "novo" era identificado com tudo que era bom, valioso e passível de estímulo; o "velho" era considerado ruim, destinado a destruição e demolição. Com Pedro [l], o povo considerava a Rússia "renascida num novo modelo", ou como um recém-nascido. (LOTMAN, USPENSKY: 1984, p. 18) (11 $^{51}$

Volodin retoma a discussão dos novos russos, tal qual Maria, ligado ao Ocidente. A inovação são guinchos no capô de um Toyota - ou seja, a superficialidade sobre algo oriental. Por fim, o ocidental na superfície; sob ele, o Oriente.

Em contrapartida, a proposta de Volodin é consumir cogumelos que farão seus companheiros (junto da fogueira) "fugirem de si mesmos" (p. 241). A fuga de si

50 No original em inglês: "(Anthropologists who have devoted their efforts to studying the 'New Russians' believe that these winches are used as rams during the settling of accounts, and certain scholars even see their popularity as an indirect indication of the long-awaited resurgence of the spirit of the nation - they believe the winches fulfil the mystical role of the figureheads that once decorated the bows of ancient Slavonic barks.)"

51 No original em inglês: "The eighteenth century came in under the banner of innovation. The 'new' was identified with all that was good, valuable and worthy of emulation; the 'old' was thought to be bad, due for destruction and demolition. Under Peter people thought of Russia as a being 'reborn in a new form' or as a new-born baby." 
próprio implica fugir da realidade do "novo russo", da realidade de 1991 e, por conseguinte, daquilo considerado superficial na nova existência do país.

A superficialidade, por sua vez, é derivada de uma recusa às formas de fuga da realidade, como se houvesse a necessidade de estar além do mundo material. Tanto o álcool de Serdiuk quanto os cogumelos de Volodin são formas de atingir um potencial "adormecido" na existência das personagens - no primeiro caso, com a proposta de emprego possibilitada durante um devaneio alcoólico.

No sonho de Volodin, o consumo dos cogumelos é justificado porque

"[...] Temos toda a loucura possível no mundo dentro de nós... Toda vez que você consome ou injeta algo, tudo que você faz é libertar alguma parte dela. Não há nenhuma loucura nas drogas, não é nada além de pó ou algumas mordidas de cogumelos... É como uma chave para um cofre. Entendeu?" (PELEVIN: 1999, p. 244) $)^{52}$

Tanto o álcool de Serdiuk quanto os alucinógenos de Volodin corroboram uma aparente necessidade de fuga da realidade em que se encontram - o primeiro, sobretudo, pela aproximação com o Oriente enquanto vive em uma Rússia que traça o caminho contrário.

Apesar de os cogumelos serem uma espécie de sequência ao álcool de Serdiuk, a proposta de Volodin não é a manutenção da loucura por meio da droga mesmo que seja a ocorrência no capítulo. Ainda assim, os três sonhos compartilham a noção de que Um breve olhar aos textos vanguardistas dos anos setenta indica que, tal
qual a iconoclastia do assunto (seja ele a preocupação com sexo e
embriaguez), o escapismo é um tema constante; esses trabalhos são
tensionados com a falta de ar da claustrofobia, sugerida não apenas por um
frenesi sintático de muitos desses trabalhos (nos quais o fluxo de
consciência se tornou uma torrente veloz), mas também pela tensão do
sentimento de confinamento dentro do físico. Eles se concentram no
desligamento do corpo, que se torna uma metáfora para o formalismo
hipócrita do texto político patriótico, agora despido pela mão da "gangue"

52 No original em inglês: "[...] We've got every possible high in the world inside us... Every time you down something or shoot up, all you do is set some part of it free. There's no high in the drug, it's nothing but powder or a few chunks of mushroom... It's like the key to a safe. Get it?"' 
dos escritores. (DALTON-BROWN: 1997, p. 222-223) (53 $^{3}$

Maria, Serdiuk e Volodin participam desse confinamento físico, evidente pela ambientação numa instituição psiquiátrica. Cada um, a seu modo, "foge" pelo sonho - que inclui sexo, álcool ou cogumelos. Por outro lado, a metafísica de Volodin extrapola uma ação no corpo que gera uma fuga temporária, expondo a seus colegas na fogueira a necessidade de se "abrir o cofre".

A liberdade exposta por esse paciente é, por vezes, uma fuga da realidade que nos cerca. Se os textos dos anos 1970 propunham o escapismo pelo sexo e pelo alcoolismo (representados, respectivamente, por Maria e Serdiuk), atingir uma liberdade por meio da mente seria um terceiro caminho. $O$ interessante é perceber que, mesmo após a queda dos soviéticos, Pelevin ainda trabalha com a necessidade desse mesmo escapismo da realidade, agora mentalmente.

Não à toa, o espaço em que acompanhamos o enredo mais verossímil de $A$ metralhadora de argila é um hospício: a última fronteira para a liberdade - não alcançada mesmo com a nova situação política russa - está na própria mente dos "novos russos". É por esta via que Volodin acredita num enclausuramento vigente, ainda que houvesse a oferta de diversas válvulas de escape à realidade.

A diferença na proposta de Volodin, portanto, compõe um quadro muito mais complexo de fuga, tanto material quanto temporalmente. Isso fica muito evidente em:

"[...] Ouça, Volodin, tudo aquilo era verdade?"

"Tudo aquilo o que?"

"Aquilo sobre arranjar-se uma viagem que dura toda sua vida... Assim você fica chapado o tempo todo."

53 No original em inglês: "A brief look at the seventies avant-gardists texts indicate that, as well as the iconoclasm of the subject-matter (that is, the concern with sex and drunkenness), escapism is a constant theme; these works are taut with the breathlessness of claustrophobia, suggested not only in the frantic syntactical rush of so many of these works (in which stream of consciousness has turned into a very swift torrent), but also through the stress on sense of confinement within the physical. They focus on the despoliation of the body, which becomes a metaphor for the hypocritical prudery of the political patristic text, now stripped bare by the hooligan hand of the authors." 


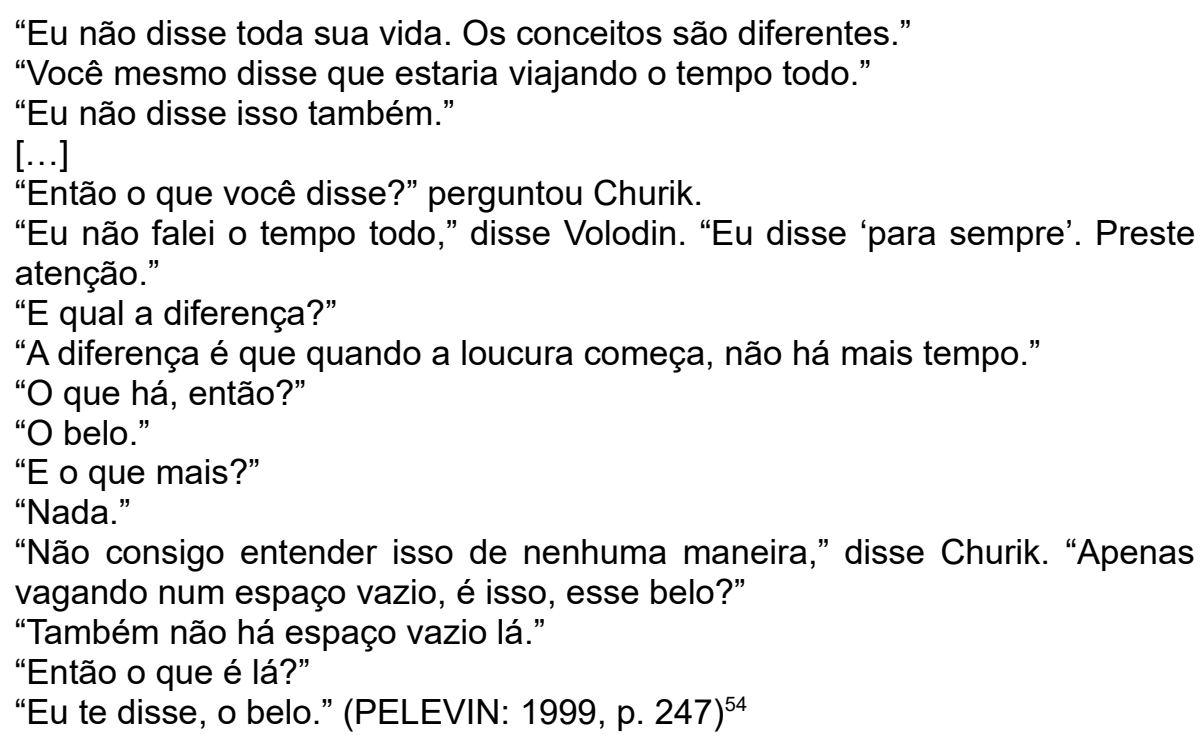

O afastamento da realidade em busca do sublime, da transcendência, de acordo com Volodin, é eternizado quando a própria mente consegue sair do "cofre" em que está presa e existir além do espaço e do tempo.

Não há no romance nenhuma análise que se aproxime mais da defesa à liberdade do que a exposta por Volodin, sobretudo no que concerne à mente dos detentos no hospício. A metafísica utilizada por Pelevin representa, ainda, uma nova crítica à sociedade russa formada pós-1991, pois a prisão (inclusive soviética, como vimos) apenas mudou de âmbito: antes social, no romance ela se tornou psicológica.

54 No original em inglês: '“[...] Listen, Volodin, was all that stuff for real?'

'All what stuff?'

'All that stuff about fixing yourself a trip that lasts all your life... So you just stay high all the time.'

'I didn't say all your life. The concepts in there are different.'

'You said yourself as you'd be tripping all the time.'

'I didn't say that either.'

[...]

'Then what did you say?' asked Shurik.

'I didn't say all the time,' said Volodin. 'I said "for ever". Keep your ears open.'

'So what's the difference?'

'The difference is where that high starts, there isn't any more time.'

'What is there then?'

'Grace.'

'And what else?'

'Nothing.'

'Can't quite get me head round that somehow,' said Shurik. 'Just hanging there in empty space, is it, this grace?'

'There's no empty space there either.'

'Then what is there?'

"I told you, grace." 
Todavia, o consumo de cogumelos alucinógenos também se fez presente, complementando o sexo de Maria e o álcool de Serdiuk. Sob efeito desses cogumelos,

\begin{abstract}
A floresta ao redor deles estava repleta de tremulantes e misteriosos raios de arco-íris, e o céu sobre a clareira estava coberto de mosaicos de incrível beleza, diferentemente de tudo que um homem encontra em sua fatigante e normal existência diária. O mundo ao redor deles mudou, se tornando muito mais cheio de significado e animado, como se tivesse finalmente ficado claro por que a grama estava crescendo na clareira, por que o vento estava soprando e as estrelas cintilando no céu. Mas a metamorfose afetou mais do que apenas o mundo, ela afetou também os homens sentados à fogueira. (PELEVIN: 1999, p. 248) 55
\end{abstract}

Os efeitos alucinógenos transformam o ambiente que os rodeia, mas também afeta as percepções que cada um tem - dos outros e de si. Kolian se "fechou em si mesmo"; Churik parecia mais magro; e Volodin, apesar de não ter mudado muito externamente, fazia movimentos aparentemente mais suaves e precisos (o que comprovava que já havia consumido esses cogumelos antes).

Aproveitando a transcendência mental, as três personagens voltam a falar sobre "o belo", relembrando um diálogo (não apresentado no romance, mas de um encontro anterior) sobre a ideia de um "promotor público interno" de cada um. Cada indivíduo, de acordo com o que explica Volodin, possui uma personagem que o controla para que se mantenha em ordem; em contrapartida, há uma testemunha que liberta esse mesmo indivíduo da culpabilidade que o promotor impõe.

Ambas as figuras são, na verdade, duas faces da mesma pessoa; atingir o belo, entretanto, contaria com outra personagem:

"[...] Apenas soa estranho eu conduzindo um caso contra mim mesmo, e então me libertando."

"Nada de estranho nisso. É assim que acontece sempre. Agora tente

55 No original em inglês: "The forest around them was filled with trembling, mysterious rainbow lights, and the sky above the clearing was covered with mosaics of incredible beauty, unlike anything a man encounters in his gruelling, normal everyday existence. The world around them changed, becoming far more meaningful and animated, as though it had finally become clear why the grass was growing in the clearing, why the wind was blowing and the stars were twinkling in the sky. But the metamorphosis affected more than just the world, it affected the men sitting by the fire as well." 
imaginar que esse seu promotor interno te prendeu, todas as suas testemunhas internas estragaram tudo e você foi preso em sua própria cela interior. Então imagine que há um outro cara, o quarto, que nunca é arrastado a lugar nenhum, o qual você não pode chamar de promotor, nem é o réu, nem uma testemunha. Que nunca se envolve em nenhum caso." "O.k., já imaginei."

"Certo, então esse quarto cara é o que viaja na loucura eterna. E não há necessidade de explicar nada para ele sobre essa loucura, você me entende?"

"Quem, então, é esse quarto cara?"

"Ninguém."

"Posso vê-lo de alguma maneira?"

"De jeito nenhum."

"Talvez não vê-lo, mas ao menos senti-lo?"

"Nem isso."

"Então isso significa que ele não existe realmente?"

"Se você quer mesmo saber," disse Volodin, "todos esses promotores e testemunhas não existem realmente. E nem você existe realmente. Se alguém realmente existe, então é ele." (PELEVIN: 1999, p. 250-251) ${ }^{56}$

Além da libertação envolvida nas testemunhas, na construção de processos mentais que compõem as ações individuais, há uma ideia implícita interessante na explicação de Volodin: o conflito. Até agora, tudo que verificamos no romance foi justificado pelo confronto de versões de mundo que atingem a identidade russa, não só entre Ocidente e Oriente, mas também pelas dualidades que apresentam Lotman e Uspensky.

Segundo o discurso de Volodin, por sua vez, o indivíduo possui dentro de si o conflito, um julgamento que impede que transcenda. É por isso que, ao citar o cofre

56 No original em inglês: "'[...] Only it sounds a bit odd, me taking a case against myself and then getting myself off.'

'Nothing odd about it. That's the way it always is. Now try imagining this inner prosecutor of yours has arrested you, all of your inner briefs have screwed up, and you've been put away in your own inner lock-up. Then imagine that there's some other guy, a fourth one, who never gets dragged off anywhere, who you can't call a prosecutor, or the guy he's trying to get behind bars, or a brief. Who's never involved in any cases at all.'

'Okay, l've imagined it.'

'Right, then this fourth guy is the one that goes tripping on the eternal high. And there's no need to explain anything to him about this high, get me?'

'Who is this fourth guy, then?'

'No one.'

'Can I get to see him somehow?'

'No way.'

'Maybe not see him then, but feel him at least?'

'Not that either.'

'So that means he don't really exist?'

'If you really want to know,' said Volodin, 'all these prosecutors and briefs don't really exist. And you really don't exist either. If anyone really does exist, then it's him.'” 
e a chave - representada pelas formas de escapar da realidade -, ele retoma a ideia de cisão e de necessidade de fuga dessa divisão. Não à toa, como já explicamos, o romance é pautado na esquizofrenia do protagonista, mas também construído pelo contato e pela experimentação das realidades dos outros detentos.

Seguindo a mesma lógica, Pelevin, ao colocar o sonho de Volodin como o último a aparecer, apresenta duas vertentes culturais que explicitam a cisão russa, e propõe uma transcendência que vai além desse conflito. É nele, sobretudo, que a prisão se encontra: Kolian ressurge do seu isolamento e propõe que quem é processado são "policiais internos" (p. 251), e que Nietzsche já havia escrito sobre esse tipo de confronto mental.

A citação de Friedrich Wilhelm Nietzsche (1844-1900) nos coloca, mais uma vez, em contato com a amplitude de referências de Pelevin - neste caso, à ideia do "super-homem" que é o porvir da humanidade. Volodin defende a "loucura eterna" da mesma maneira que a superação do ser humano pelo übermensch nietzschiano, de acordo com Kolian.

O que é mais notável, tanto na exposição de Volodin quanto na dubiedade de Kolian, é a transposição da filosofia de Nietzsche para um âmbito psicológico que se dispõe a questionar a formação conflituosa da identidade russa. Não à toa, quando Volodin responde a seu "colega", a ideia de que uma "evolução individual" é muito presente, sobretudo para derrotar uma espécie de "Estado interno" que nos controla e impede nossa liberdade.

A revolução individual implicaria, segundo Volodin, na libertação em relação, também, dos nossos "policiais", que nos condenam nas ações. Eles querem nos ver presos, mas comportam em si o conflito do processo e um desejo de autocontrole - 
incluído na tomada de poder, seguindo a lógica de Kolian (p. 252 e 253) e na inocência de acreditar que é um poder eterno.

Volodin não apenas questiona as formas de liberdade compreendidas na nova democracia russa, mas contribui para uma discussão sobre quem são os indivíduos que formarão o país futuro. Tomar o poder de um governo repressor não significa se libertar, pois novas formas de repressão surgirão e se adaptarão à nova sociedade. Isso fica evidente quando ele retoma Nietzsche, agora relembrando o fim do filósofo: internado após um colapso mental - ou seja, sob custódia.

O aprisionamento de Nietzsche contribui para a teoria de Volodin de que o cumprimento da "loucura eterna" está além das figuras que conhecemos justamente porque transcendem à nossa existência. Isso porque

"[...] Às vezes você é um policial e às vezes você é o cara para quem ele está apontando. Às vezes você é o promotor, às vezes você é a testemunha. Por que você acha que falei que eles não existem realmente? Porque quando você é o promotor - onde está a testemunha? E quando você é a testemunha - onde está o promotor? Em lugar nenhum. Então acontece que você os está sonhando, me entende?"

"O.k., o.k., eu entendo."

"E então, além dos policiais, você possui vários outros imbecis esperando na fila, de forma que a vida não é longa o suficiente para você ser todos eles. A fila esperando por você aí dentro é mais longa do que as filas por salsicha durante o comunismo. E se você quer entender a loucura eterna, você precisa acabar com a fila, me entende?" (PELEVIN: 1999, p. 254$255)^{57}$

Cada figura que nos parece real é, na verdade, uma faceta da realidade individual que se faz presente na existência. Atingir a loucura eterna significa superar essas facetas possíveis, um desligamento do mundo material e existencial para se transcender.

57 No original em inglês: "[...] Sometimes you're a pig, and sometimes you're the guy he's fingering. Sometimes you're the prosecutor, sometimes you're the brief. Why d'you think I said they don't really exist? Because when you're the prosecutor - where's the brief? And when you're the brief where's the prosecutor? Nowhere. So it turns out like you're dreaming them, get me?'

'Okay, okay, I get you.'

'And then apart from the pigs, you've got so many other assholes standing in line that life's not long enough for you to be all of them. The queue waiting for you inside is longer than any of those queues for sausage under the commies. And if you want to understand the eternal high, you have to wipe out the whole queue, got me?" 
O individualismo de Volodin, explícito na ideia de que cada indivíduo deve se libertar de suas possibilidades de "eu", uma potência [aristotélica] de identidade que será superada pela transcendência individual. Isso fica muito evidente quando Volodin diz a Kolian que a crença no fim do mundo é uma "questão puramente individual" (p. 256); e Kolian, por fim, entende que o "sistema" funciona como uma subida em direção à divindade ou uma descida rumo a uma cela de punição (p. 257).

Ao passo que há uma divisão em dois polos, o sonhador que acompanhamos lembra uma figura que seus colegas esquecem:

\begin{abstract}
"Vocês se esqueceram do acusado, não foi?" perguntou Volodin. "Aquele que estão todos julgando? Você não pode se deslocar diretamente entre ser o promotor e sua própria testemunha. Você precisa ser o acusado por ao menos um ou dois segundos. Ele é o terceiro cara. Mas o quarto cara não está em nenhuma dessas ações. Não há nada de que ele precise além da loucura eterna." (PELEVIN: 1999, p. 260) ${ }^{58}$
\end{abstract}

A proposição de Volodin é a de que, normalmente, migramos entre os papéis num "tribunal interno", seja na consciência que temos de nossos atos, seja na defesa deles ou, ainda, na lembrança para defender nossas ações. Este é o sistema que Churik reconhece em nossos processos mentais, por exemplo.

A loucura eterna, que é, inclusive, almejada pelas personagens que fazem parte deste capítulo, significa uma fuga do sistema - e, por conseguinte, de uma lógica do funcionamento da mente, segundo Volodin. Se, conforme vimos, antes a preocupação era com a liberdade política, agora deve-se escapar de uma prisão mental e dos processos que estão atrelados a ela.

A questão metafísica que este sonho sugere é a libertação da própria ideia de consciência, ultrapassando nossas percepções e construindo a realidade enquanto uma "loucura" que supera as barreiras estabelecidas no "sistema jurídico" da mente.

58 No original em inglês: 'YYou've forgotten the accused, haven't you?' asked Volodin. 'The one they're all trying? You can't shift straight from being your own prosecutor to being your own brief. You have to be the accused for at least a second or two. He's the third guy. But the fourth guy isn't on any of those deals. There's nothing he needs except this eternal high." 
O caráter sobre-humano fica muito evidente quando Volodin diz que o quarto cara pode ser chamado de "filho de Deus" (p. 261); mais ainda quando o desligamento da humanidade (tanto do corpo quanto da mente) é dificultado porque "o problema é que a única maneira de se tornar o quarto cara é parar de se tornar todos os outros" (p. 262) $)^{59}$.

Como clímax para toda a elucidação de Volodin, somado aos efeitos dos cogumelos, Kolian, que fora durante todo o sonho a personagem mais distante, ressurge (durante os novos questionamentos de Churik) à beira da fogueira, mas com um raio de luz sobre sua cabeça. A sugestão de iluminação num contexto que questiona bastante a racionalidade é bastante significativa, pois Pelevin nos incita a exceder os processos mentais e libertar nossa existência com isso.

A relação com o lluminismo não é acidental, mas também não há uma defesa propriamente dita do contexto oriental. Volodin permite uma nova interpretação do romance ao estar além da divisão entre Maria e Serdiuk: deixa de "se tornar todos os outros". A loucura eterna a que ele se refere, então, não é um processo mental, mas uma abertura para algo que transcende a temporalidade e espacialidade, representadas pelos outros sonhos.

Essa transcendência mental não só é importante para o desenvolvimento do romance - ao que retornaremos no capítulo sobre o protagonista -, mas também estimula o leitor a ter uma nova visão sobre a leitura. Volodin dá uma amplitude metafísica muito maior à questão da identidade, que deve ser esvaziada de tudo que evita e controla a sublimidade da mente. Não apenas produzimos nossas ideias, mas também as censuramos e nos censuramos; apesar de colocar a sanidade de

59 No original em inglês: "The problem is that the only way to become the fourth guy is to stop turning into all the others." 
Nietzsche em xeque, é neste sonho que Pelevin nos mostra tal referência, sobretudo à filosofia niilista de questionamento a categorias morais.

A defesa que Pelevin faz dessa transcendência se afirma enquanto Churik e Volodin conversam ao atingir tal estado:

\author{
"Nossa. Volodin, você consegue me ouvir?" \\ "Sim," Volodin respondeu de todo lugar. \\ "Esta é a eterna loucura, então?" \\ "Por que você está me perguntando? Olhe por si mesmo. Você sabe de tudo \\ agora, você consegue ver tudo." \\ "É... O que é este negócio ao nosso redor? Ah, sim, é ela... Com certeza. \\ Mas para onde foi tudo?" \\ "Não foi a lugar algum. Tudo está onde deveria estar. Tente olhar com mais \\ atenção." (PELEVIN: 1999, p. 263) 60
}

O autocontrole de Volodin é marca indiscutível de que ele já havia atingido tal estado anteriormente; por outro lado, a superação do espaço físico é evidente quando ele ocupa todo o redor de Churik. Ainda mais relevante é a noção de que o tudo reconhecível por Churik some, mas "está onde deveria", como se este fosse o estágio máximo da verdade e realidade.

Esse momento logrado por Volodin tem significância por representar um indício não só do movimento, mas do estilo literário de Pelevin:

\begin{abstract}
A criação deliberada de mundos que orbitam entre si numa lógica confusa, sufocando-se até a morte, ou que perdem toda a forma até se tornarem gritos, berros, sequências de letras sem sentido, é outra forma de "anticriação".

[...] Na obra de Victor Pelevin, pode-se encontrar a criação de um universo artificial no qual mudança leva a questionar a natureza de sua criação. Não há saída, mas a inserção de um forte elemento de humor transforma a crueldade deste pós-modernista russo em um tipo mais levemente lúdico de texto; o desespero se torna lúdico. Os textos de Pelevin trabalham levemente com ideias filosóficas, em especial com a relação epistemológica do observador com os fenômenos. Seus textos são metaficcionais (e, como parte de uma autorreflexão textual, pode-se ver que suas personagens são paródias conscientes de "criadores" do Realismo Soviético"). [...]" (DALTON-
\end{abstract}

60 No original em inglês: “'For real. Volodin, can you hear me?'

'Yes,' Volodin answered from everywhere.

'Is this the eternal high then?'

'Why are you asking me? Look for yourself. You know everything now, you can see everything.'

'Yeah... What's this stuff all around us? Ah, yes, that's it... of course. But where's everything gone to?'

'It hasn't gone anywhere. Everything's where it should be. Try looking a bit harder...' 
BROWN: 1997, p. 226) ${ }^{61}$

A "metaficção" aqui referida está muito presente na transição entre realidades que acompanhamos: um protagonista que nos narra o romance; as duas realidades em que o acompanhamos; os sonhos dos quais ele participa (de acordo com o tratamento de Timurovitch); as diferentes camadas de realidades apresentadas pelos detentos do hospício.

Em contrapartida, atingir o nível de reflexão que nos permite reconhecer essas realidades paralelas com as quais convivemos não é apenas positivo: Churik, por exemplo, se assusta (e, conforme vimos, aparecem gritos de terror ao "olhar a si mesmo"). A decomposição do mundo ao redor, seguida de uma autorreflexão das personagens, produz um medo das personagens - exceto Volodin -, que devem, por fim, seguir em direção à floresta (que surgirá assim que correrem em direção a ela) para se salvarem da escuridão e do temor que os habitam (p. 264).

É justamente no movimento que há um retorno à realidade anterior, ao "tudo" com que estão acostumados a conviver. Quando correm em direção à floresta, ainda que ela não seja visível, os três - Volodin, Churik e Kolian - passam a ocupar uma posição no espaço em que se encontram, num recuo em relação ao esvaziamento e à loucura eterna que almejavam.

Disso resulta uma sensação, para Churik, de que houve uma explosão da qual fugiram; contudo, a conclusão a que ele chega é de que "tudo ocorreu dentro da

61 No original em inglês: "The deliberate creation of words which loop around themselves in tortuous logic, strangling themselves to death, or which lose all form until they become shouts, screams, strings of meaningless letters, is another form of anti-creation.

[...] In the work of Viktor Pelevin, one finds the construction of an artificial universe which at every turn calls into question the nature of its creation. There is no way out, but the insertion of a strong element of humour turns this Russian postmodernist into a more lightly ludic type of text; despair becomes ludicrous. Pelevin's text deal lightly with philosophical ideas, in particular the epistemological relationship of observer to phenomena. His texts are metafictional (and, as part of textual self-reflexivity, one finds that his characters are conscious parodies of socialist realist 'creators')" 
mente" (p. 266). A confirmação de Volodin só evidencia que esse momento explosivo foi o estado que buscavam - o retorno, aliás, possuía chamas tais quais as da fogueira. Ao atingirem a loucura eterna, a saída se deu por elementos ligados ao espaço que os rodeava simultaneamente ao estado mental transcendental.

O rompimento com o que seria uma condição sublime da mente, então, é representado por um momento violento, retrocedendo da elevação espiritual ao medo e, por fim, à realidade materializada. O fogo parece trabalhar como elemento catalisador dessa transição, seja pela rebentação, seja pela percepção de retorno à fogueira.

Conforme podemos imaginar - e é ratificado por Volodin -, a loucura eterna é atingida primeiramente por Kolian, que estava ensimesmado quando Churik pôde ver o raio de luz sobre a cabeça de seu colega. O compartilhamento desse estado mental é uma referência de certa forma evidente à condição do hospício, onde cada detento participa dos sonhos dos outros.

Essa relação se torna indiscutível quando, ao saírem da clareira com o carro, Churik começa a interrogar Volodin sobre o que haviam testemunhado:

\footnotetext{
"Ouça," ele disse, finalmente. "Há ainda algo que eu não entendo. Você disse que uma vez que se atinge a loucura eterna, ela nunca acaba."

"Ela nunca acaba," Volodin respondeu, franzindo as sobrancelhas enquanto virava bruscamente o volante, "não se você chega a ela pelo caminho normal, pela porta da frente. Mas poderia dizer que escalamos pela janela de trás. É por isso que o alarme soou."

"Um alarme forte," disse Churik, "algo realmente forte."

"Aquilo não foi nada," disse Volodin. "Eles poderiam facilmente ter nos descartado. Há casos assim. Pegue aquele Nietzsche do qual Kolian estava se queixando, é exatamente o que aconteceu com ele."

"Mas se te capturam lá, onde te colocam?" Churik perguntou com um estranho tom de respeito em sua voz.

"No plano físico - no hospício. Mas onde te colocam no plano profundo, eu não sei. É um mistério."

"Ouça," perguntou Churik, "você pode chegar lá simplesmente assim? Quer dizer, quando quiser?"

"Nah," disse Volodin. "Eu... Como posso explicar? Eu não posso me esgueirar pela brecha. Eu já peguei muitas riquezas espirituais na minha vida. E depois me livrar delas é mais difícil do que limpar a merda nas fendas da sola do seu sapato. Então eu geralmente envio um dos pobres de
} 
espírito à frente, assim ele pode se esgueirar pelo buraco da agulha e abrir a porta de dentro. Como desta vez. Mas eu não achava que adentrar dois pobres de coração juntos criaria tal desordem." (PELEVIN: 1999, p. 267) ${ }^{62}$

Fica muito óbvia a associação do delírio mental ao estado de elevação espiritual desejado pelas personagens: o que é passível de enclausuramento social também é uma condição de liberdade.

O nirvana promovido neste capítulo significa mais do que apenas uma "viagem" ocasionada por alucinógenos: obtê-lo por meio dos narcóticos é descrito como a "janela de trás"; no início, vimos que há pessoas que vão a mosteiros para devotar suas vidas a chegar a tal estado. Nas entrevistas aqui disponibilizadas, Pelevin é retratado como uma figura peculiar que, além de ser dificilmente acessível ao público, passa vários meses do ano em templos budistas, sobretudo na Coreia do Sul.

O que Volodin nos mostra como a loucura eterna, portanto, pode ser análogo ao estado de sublimidade experimentado pelo autor nos seus retiros espirituais. Não à toa, o que sentimos ao ler esse oitavo capítulo do romance é uma espécie de estranheza, já que seu aspecto metafísico extrapola a Moscou de Maria e de Serdiuk, num isolamento em direção à floresta (e uma clareira, como imagem da

62 No original em inglês: ''Listen,' he said at last. 'There's something else I don't get. You said that once the eternal high hits you it never ends.'

'It doesn't never end,' Volodin replied, frowning as he turned the steering wheel sharply, 'not if you get in the normal way, through the front door. But you could say we climbed in through the back window. That's why the alarm went off.'

'Some heavy alarm,' said Shurik, 'real heavy stuff.'

'That's nothing,' said Volodin. 'They could easily have put us away. There are cases like that. Take that Nietzsche Kolyan was jawing about, that's exactly what happened to him.'

'But if they collar you there, where do they put you?' Shurik asked with a strange note of respect in his voice.

'On the physical plane - in the madhouse. But where they put you on the subtle plane, I don't know. That's a mystery.'

'Listen,' asked Shurik, 'can you get there as simple as that? Like, whenever you want?'

'Nah,' said Volodin. 'I... How can I explain it? I can't squeeze through the gap. I've picked up a lot of spiritual riches in my life. And getting rid of them afterwards is harder than cleaning the shit out of the grooves on the sole of your shoe. So I usually send one of the poor in spirit on ahead so he can squeeze through the eye of the needle and open the door from the inside. Like this time. But I didn't think that if two poor in heart got in together they would create such a rumpus."' 
centralidade das personagens em um local "selvagem").

A importância deste constructo de realidade, aplicado ao sonho de um dos companheiros do protagonista, está na experimentação de um terceiro estado de identidade: um espiritual que está além da materialidade e da cisão entre Ocidente e Oriente. Se antes o que lemos propunha possibilidades de identificação muito palpáveis, agora somos estimulados a explorar uma outra faceta dessa individualidade concebida por Pelevin.

Não obstante, a ideia de que as personagens na clareira se assemelham a neoplatônicos remete diretamente à "Alegoria da Caverna", de Platão, sobre Homens que veem apenas sombras da realidade na parede da caverna que habitam. Volodin é a personagem através da qual Pelevin cria uma alegoria semelhante: em vez da caverna, estamos presos em um cofre; vemos apenas a fogueira à nossa frente, e precisamos transcender em direção à liberdade - no caso, o suporte são cogumelos ou, para fazê-lo "pela porta da frente", dedicando a vida a atingir o estado sublime da libertação.

A loucura eterna que experimentam Volodin, Churik e Kolian é comparável ao efeito que a Filosofia tem para os Homens que saem da caverna e descobrem que o real está além das sombras. O enclausuramento mental, por outro lado, surge no romance como o estado aceito socialmente - numa crítica de Pelevin à forma que tomou o conceito de liberdade na Rússia pós-soviética. Equiparar Volodin a Sócrates, seguindo a comparação com o texto platônico, significa que a pretensão de transcender a realidade é motivo para internação, e não libertação.

O nirvana, portanto, seria tratado como patologia psiquiátrica, e não como um estado sublime da existência. Há uma crítica semelhante na entrevista à revista New 
York Times, disponibilizada na página 54 desta dissertação, quando Pelevin diz que "na época dos soviéticos você podia escapar do mal do Estado ao se retirar para os espaços particulares de sua própria mente; mas agora o mal parece ter se espalhado por todo lugar. Nós somos todos contaminados por ele"63.

Isso também nos aproxima da ideia, já apresentada, de que a criação de identidades se expandiu como um negócio pela Rússia pós-soviética (p. 43 desta dissertação), mas, para Pelevin, foi um processo extremamente superficial. Enquanto se multiplicam, essas identidades não acompanham uma transcendência à materialidade do novo estado em que os russos existem.

Por isso o exemplo de Nietzsche é interessante: porquanto seja o filósofo que rechaça a moralidade imposta ao indivíduo - sobretudo nos conceitos de Bem e Mal -, foi internado após um colapso mental. Volodin apresenta Nietzsche como alguém que atingiu a loucura eterna, mas que foi capturado enquanto estava nesse estado; a sociedade é ferida, no âmbito físico, pela transcendência, inclusive pelo questionamento a dogmas morais e sociais.

A "luz" que surge sobre Kolian é fruto do trabalho de Volodin, que, no romance, cumpre o papel do Zaratustra de Nietzsche, ou do Sócrates da caverna de Platão, ao menos em seu sonho. Seu confinamento como doente mental, então, faz parte da crítica de Pelevin à forma como são tratadas formas de transgressão a uma espécie de "ordem psicológica" imposta. A liberdade da mente não está, por exemplo, condicionada à liberdade de mercado decorrente da abertura de 1991.

Até agora caminhamos por uma Moscou hollywoodiana, por uma mesma Moscou nipônica e, enfim, sentamos em frente a uma fogueira para tentar ascender

63 No original em inglês: "In the Soviet times you could escape from the evil of the state by withdrawing into the private spaces of your own head; but now the evil seems to be diffused everywhere. We are all tainted by it."' 
nossa mente a um estado sublime: três momentos do romance que têm em si três facetas da identidade russa - históricas e, com Volodin, uma proposta de libertação. Sexo, álcool e drogas alucinógenas acompanharam as personagens, seus desejos e interpretações sobre o mundo em que vivem.

Finalmente chegamos à análise sobre o protagonista, Piotr, que vivenciou esses sonhos tal qual o leitor e narrou-nos sua experiência. Isso contribui para que se reconheça no hospício - realidade que Timurovitch tenta impor a ele como a única verdadeira. Este processo, acompanhado pela ideia de que $A$ metralhadora de argila é um romance de formação (LIPOVETSKY: 2001, p. 47), colabora para nossa proposição de que Pelevin criou seu protagonista visando a compor um perfil enraizado e ao mesmo tempo em transformação do que seria o indivíduo russo resultante das profundas mudanças em seu país após 1991.

\section{Piotr como síntese da cisão}

Já no prefácio se promove uma diferenciação do Tchapaiev que foi personificado pelo Realismo Socialista do Tchapaiev que será apresentado no romance (p. x). Pelevin trata ironicamente a visão de "herói do Exército Vermelho", como se ela fosse uma ficção construída por falta de conhecimento; por outro lado, propõe logo de início que $A$ metralhadora de argila é um registro em diário do comissário de Tchapaiev - Petka, diminutivo de Piotr, em russo.

Nesse mesmo prefácio, então, há uma informação decerto curiosa, segundo a qual o texto tinha outro título (Vasily Chapaev), mas foi mudado para evitar confusões com o romance Chapaev e o filme homônimo, ambos produzidos pelo 
Realismo Soviético. Haveria uma outra possibilidade - além de $A$ metralhadora de argila -, que seria $O$ jardim dos Petkas divergentes, sugerido pelo editor (já fazendo parte da ficção do romance), e que nos dá uma pista de quem seria o verdadeiro protagonista.

Isso se confirma na leitura do primeiro capítulo, quando começa a narração em primeira pessoa, com Piotr caminhando por Moscou, vindo de São Petersburgo um caminho geograficamente interessante, se considerarmos o que vimos até aqui sobre a representatividade de cada cidade e das estimas de Pelevin. Conforme acompanhamos Piotr, sua caminhada é interrompida pelo reencontro com um excolega, Grigory Vorblei, que convida o protagonista a conhecer seu apartamento.

O ex-colega, por seu turno, passará a representar a repressão, que já vimos presente em todos os momentos não só históricos na Rússia, mas também nos sonhos do romance: ele se tornou agente da Cheka, polícia secreta criada pelos soviéticos. O reencontro não fora acidental, mas planejado para que Piotr fosse detido, algo que se justificaria no trecho:

"Eu não fiz absolutamente nada. Parece estúpido até falar disso. Eu
publiquei um poema em um jornal, mas não era um jornal que não recebeu
a aprovação deles. E havia uma rima nele de que eles não gostaram: 'rubro'
e 'estúpido'. Você consegue imaginar isso?"
"E sobre o que era o poema?"
"Ah, era completamente abstrato. Era sobre o fluxo do tempo lavando a
barreira do presente, e então novos padrões seguiam aparecendo, e nós
chamamos alguns deles de passado. Nossa memória nos diz que ontem
realmente existiu, mas como podemos ter certeza de que todas essas
memórias não surgiram ao alvorecer?" (PELEVIN: 1999, p. 7$)^{64}$ Tendo conhecimento da divisão do romance em dois núcleos temporais,

64 No original em inglês: "I did absolutely nothing at all. It sounds stupid even to talk about it. I published a poem in a newspaper, but it was a newspaper which didn't meet their approval. And there was one rhyme they did not like either: "Red" and "Mad". Can you imagine that?'

'And what was the poem about?'

'Oh, it was completely abstract. It was about the stream of time washing away the wall of the present so that new patterns keep appearing on it, and we call some of them past. Our memory tells us that yesterday really existed, but how can we be sure that all of these memories did not simply appear with the first light of dawn?"' 
percebemos que esse mesmo fluxo do tempo referido é exatamente o que age sobre a mente de Piotr, levando-o à realidade deste primeiro capítulo (1919) durante seus sonhos em 1991. Contudo, o reencontro dura pouco, e Vorblei recebe ordem para deter seu ex-colega, transformando a conversa amistosa em uma breve luta, na qual Piotr mata Vorblei no apartamento.

Se a descrição do assassinato é concisa, os acontecimentos posteriores tomam uma complexidade de certo modo inesperada:

Assim que levantei, fui esmagado pela percepção de que eu tinha cometido um assassinato.

Naturalmente, como qualquer um que não confiasse totalmente nas autoridades, eu carregava um revólver, e dois dias antes eu não tive escrúpulos ao utilizá-lo. Mas isso era diferente, isso era cena sombria de Dostoievski: um apartamento vazio, um corpo coberto por um casaco de modelo inglês, e uma porta levando a um mundo hostil - uma porta talvez já sendo abordada por pessoas atraídas pela curiosidade. Com força de vontade, afastei esses pensamentos de minha mente. A atmosfera dostoievskiana, certamente, não era criada pelo cadáver ou pela porta com um buraco de bala, mas por mim mesmo, por minha própria consciência, que havia absorvido as formas de um arrependimento alheio. (PELEVIN: 1999, p. 10 $)^{65}$

A luta entre ambos terminou com Vorblei morto, estrangulado sob o casaco de Piotr; a marca do tiro na porta é decorrente da reação de seu ex-colega durante o entrevero.

A profundidade está na comparação com uma cena de Dostoievski, pois Piotr se vê numa situação semelhante à do protagonista Raskolnikov, de Crime e castigo. A comparação é viável, pois a ideia de uma consciência que assombra a personagem após cometer um assassinato - e causa o arrependimento - é o que afeta Raskolnikov psicologicamente, e se torna a "vilã" do romance de 1866.

65 No original em inglês: "As I stoop up, I was overwhelmed by the realization that I had committed murder.

Of course, like anyone who did not entirely trust the authorities, I carried a revolver, and two days before I had had no qualms about using it. But this was something different, this was some dark scene out of Dostoevsky: an empty flat, a corpse covered with an English-style coat, and a door leading to a hostile world - a door perhaps already being approached by people attracted by idle curiosity. By an effort of will I banished these thoughts from my mind. The Dostoevskian atmosphere, of course, was not created by the corpse or the door with its bullet hole, but by myself, by my own consciousness, which had assimilated the forms of another's repentance." 
Além da citação direta ao autor clássico, a referência a Raskolnikov carrega consigo a raiz raskol, que em russo significa cisma. Conforme vimos, se a cultura russa é historicamente composta por cisões, nada mais esperado do que a figura de um cisma para caracterizar um dos maiores protagonistas da literatura do país - e, posteriormente, a mesma divisão ser revivida num romance pós-moderno.

Como evidência disto, temos a primeira troca de identidade em $A$ metralhadora de argila: Piotr troca seu casaco e seu revólver pelos respectivos de Vorblei. Novamente, sabendo do mote do romance, retomamos o conceito de metaficção, numa esquizofrenia que abarca o sonho de 1919 do protagonista; o cisma se estabelece em Piotr já nas primeiras páginas do romance, com Raskolnikov como referência.

Seguindo a ação desse momento, Piotr cria um cenário em que é o censor acionado para a [sua própria] detenção. Tomando para si todos os pertences de Vorblei, a troca de identidade é facilitada (o que nos leva a duvidar da plausibilidade - sobretudo por não reconhecerem o oficial que deveria efetuar a prisão -, a qual, depois, é justificada por ser um sonho). Apesar da aplicação materializada desta mudança, o que mais chama a atenção é o contexto psicológico de apropriação de identidade.

Também é significativo o método de persuasão de que se utiliza Piotr: ele oferece, de dentro de uma maleta que era carregada por Vorblei, uma porção de cocaína, a qual os policiais Barbolin e Zherbunov, que encontram a cena do homicídio ao buscarem seu "colega" (agora morto) adicionam a uma dose de vodca. Logo de início já vemos álcool e narcóticos relacionados à relação com a realidade e, inclusive, à negação dela, já que os oficiais ignoram a possibilidade de troca de 
identidade, sequer investigando o cadáver.

Com isso, levam Piotr a um "cabaré literário", onde ele reportaria o sucesso de sua missão (como Vorblei) a superiores. Nesse momento, a encenação que se dava era uma tragédia intitulada "Raskolnikov e Marmeladov", óbvia referência a Crime e castigo, na qual

De um lado temos um falastrão, que se revela todo a quem queira ouvir, de
outro temos o protagonista na posição de espectador, quase sem se
manifestar, de tal modo que fica a cargo do leitor construir as linhas de
intersecção entre esses personagens e compreender a finalidade artística
do monólogo de Marmeladov nesse ponto do texto. Ainda que o narrador
seja onisciente somente em relação a Raskolnikov, neste episódio, verifica-
se que o que é dito acerca da sua relação diante de Marmeladov é bem
pouco elucidativo, se comparado ao que aparece diretamente no discurso
do bêbado.
Tudo na cena da taberna carrega a marca da ambiguidade. (MARQUES:
2010, p. 37 ) Vemos como base da citação de Pelevin um trecho do romance de Dostoievski em que o álcool é elemento predominante, mas algo que nos chama a atenção é o fato de que o narrador é onisciente somente aos acontecimentos com Raskolnikov.

Ora, se em Crime e castigo o protagonista é o único que é acompanhado ininterruptamente pelo narrador, em $A$ metralhadora de argila, cuja cisão não está no nome do protagonista, mas na mente dele, Piotr é o próprio narrador. Mais uma vez o álcool é apresentado como substância da alteridade - seja em Marmeladov ou Serdiuk -, mas é permissivo para libertação das personagens. Aqui podemos, inclusive, construir uma ponte entre a referência direta e o maior trabalho de Pelevin com a personagem que representa o Oriente em seu romance, e que só consegue seu emprego por causa da bebedeira.

Por outro lado, a ideia de ambiguidade contida no contexto analisado é mister se pretendemos entender a cisão do protagonista de $A$ metralhadora de argila. Já vimos que há uma mudança de identidade forçada pela repressão policial no 
momento de 1919; isso se intensifica quando, durante a encenação,

O pensamento de Marmeladov se tornou cada vez mais ambíguo. Sugestões sombrias começaram a emergir no fluxo de suas palavras: a comparação da manhã cinzenta de São Petersburgo com um golpe de um machado na nuca, de sua alma cansada do mundo com um quartinho escuro em que estivessem corpos de mulheres mortas. A isso, Raskolnikov começou a mostrar sinais evidentes de nervosismo, e ele perguntou o que Marmeladov queria. Meio atrapalhado, Marmiéladov pediu a ele que vendesse o machado. (PELEVIN: 1999, p. 19) ${ }^{66}$

Vemos aqui que a questão da ambiguidade é muito presente não só na abertura para com o protagonista, mas também na relação que se tem com o homicídio. Piotr se interessa pela cena não só pela reação de Raskolnikov, mas porque o conteúdo da culpa se assemelha ao arrependimento que sentiu no momento em que percebeu que cometera um assassinato.

Interessante é a relação que ele faz ao final da estadia no cabaré, ainda fingindo ser agente da Cheka:

[...] hoje eu também tive garantida a honra de passar por cima da minha própria velha, mas vocês não vão me asfixiar com os dedos imaginários dela. Oh, que a danação leve essas eternas obsessões dostoievskianas que perseguem os russos! $\mathrm{E}$ que a danação leve nós, russos, que não conseguimos ver mais nada ao nosso redor! (PELEVIN: 1999, p. 22) ${ }^{67}$

Durante essa reflexão, percebe-se que Piotr reconhece uma repetição de Dostoievski na cultura russa, ao que podemos relacionar ele próprio, sentindo-se um novo Raskolnikov, e, no seu caso, descobriremos que a cisão psicológica é o elemento dostoievskiano que o acompanha.

Por outro lado, a mudança na narrativa de Crime e castigo é mais um elemento metaficcional, numa terceira camada de realidade que surge: a primeira,

66 No original em inglês: "Marmeladov's meaning grew more and more ambiguous. Dark hints began to surface in the flow of his words: a comparison of the grey of St Petersburg morning with a blow from an axe to the back of the head, of his own world-weary soul with a dark closet in which the bodies of dead women lay. At this Raskolnikov began showing clear signs of nervousness, and he enquired what Marmeladov wanted of him. In some confusion, Marmeladov asked him to sell the axe."

67 No original em inglês: "[...] today I was too was granted the honour of stepping over my own old woman, but you will not choke me with her imaginary fingers. Oh, damnation take these eternal Dostoevskian obsessions that pursue us Russians! And damnation take us Russians who can see nothing else around us!" 
Piotr; a segunda, fingindo ser Vorblei e agente soviético; e a terceira, a encenação.

Dali, Piotr precisa sair depois de causar tumulto ao apresentar um poema convocando os espectadores à Guerra Civil - consolidando o tempo dessa narrativa em 1919.

O capítulo termina com Piotr saindo no veículo que o levara ao cabaré, mas com uma transformação da confiança e segurança que marcaram a primeira impressão durante o contato com Vorblei:

De repente, eu fiquei perfeitamente consciente de quão sozinho e vulnerável eu estava neste mundo congelado, populado por pessoas que querem ou me entregar para a Cheka, ou perturbar minha alma com a magia sombria de suas palavras confusas. Amanhã de manhã, eu pensei, terei de dar um tiro em meu cérebro. A última coisa que vi antes de finalmente cair no escuro abismo do esquecimento foram os trilhos cobertos por neve seguindo a rua, os quais se aproximaram da janela enquanto o carro finalmente virava. (PELEVIN: 1999, p. 27) ${ }^{68}$

O desejo de liberdade é iminente: o suicídio significa uma fuga não só da farsa de identidade, da perseguição bolchevique. Ele tem como finalidade uma libertação da alma, deixando para trás a confusão, o sentimento de isolamento e um mundo que não entendia.

Do primeiro para o segundo capítulo, o salto histórico se dá diretamente no momento inicial de consciência: Piotr se vê preso em uma camisa de força, e começa a teorizar que foi capturado pela Cheka. Considera que, em um instante de desatenção, deve ter entregado a intenção de se suicidar, o que teria motivado sua internação.

A interpretação é corroborada pela presença de Zherbunov e Barbolin, mas, para sua surpresa, eles estavam mudados, vestidos com avental médico. Tal

68 No original em inglês: "I was suddenly keenly aware of how alone and vulnerable I was in this frozen world populated by people keen either to dispatch me to the Cheka or to perturb my inner soul with the dark sorcery of their obscure words. Tomorrow morning, I thought, I will have to put a bullet through my brain. The last thing I saw before I finally collapsed into the dark it of oblivion was the snow-covered railing along the street, which came up very close to the window as the automobile finally turned." 
mudança de ambiente - de uma Moscou em vias de explodir pela Guerra Civil, uma libertação do controle da Cheka e a fuga dessa prisão em direção a um hospício, uma camisa de força e "colegas" agora como "enfermeiros" - confunde a visão de Piotr da realidade. Subsequente à decisão do suicídio, a ideia de morrer não o assusta mais, e ele aceita passivamente o que seria sua execução.

Como ainda crê estar vivendo na Guerra Civil, a aparição do psiquiatra Timur Timurovitch se equipara a uma sala de interrogatório, na qual a insubordinação de Piotr será revelada. A primeira pergunta, por sua vez, é como Piotr se envolveu em uma confusão tão grande, o que pode ser lido tanto no contexto de 1919 quanto em 1991. O que mais chama a atenção, de fato, é a escolha por esses dois momentos da história russa.

Iniciar o romance com a Guerra Civil Russa no plano de fundo permite-nos identificar um conflito interno, o que pode ser identificado como uma analogia à própria Guerra Civil. Quando Piotr explica a Timurovitch (ainda achando que ele é um investigador da Cheka) que não será um suspeito útil, pois passara a vida inteira evitando o contato social (p. 31), o que ressurge à nossa memória é esse mesmo conflito nacional russo e o processo posterior de isolamento político da União Soviética em relação ao mundo capitalista.

É com este sentimento que podemos analisar a primeira leitura que Piotr faz do pôster sobre a cabeça de Timurovitch:

Era um pôster, impresso nas cores da bandeira russa e preso em uma grande cartolina, retratando um homem azul com um semblante tipicamente russo. Seu peitoral havia sido aberto e o topo de seu crânio serrado para expor seu cérebro vermelho. Apesar do fato de suas vísceras terem sido extraídas de seu abdômen e enumeradas por algarismos latinos, a expressão em seus olhos aparentava indiferença, e seu semblante parecia congelado em um calmo e leve sorriso; por outro lado, talvez aquilo era simplesmente o efeito criado por um enorme corte em sua bochecha, pelo qual eu podia ver parte de sua mandíbula e dentes tão explicitamente quanto em um comercial de pasta de dentes alemã. (PELEVIN: 1999, p. 30- 
$31)^{69}$

À primeira vista, parece um quadro de terror que choca Piotr, mas trazendo uma interpretação relevante sobre o que pode vir a ser a ideia do autor: a razão, representada pelo cérebro visível no pôster, é preenchida pela cor vermelha, o que poderia significar o momento da realidade em que o protagonista se encontra - de domínio bolchevique, ligado à cor vermelha.

O isolamento é justificado durante o inquérito com Timurovitch, mas também sob o olhar da razão comunista, de acordo com a visão de Piotr. Como complemento, ainda temos a justificativa da fuga do convívio social:

\begin{abstract}
"Se qualquer um tentar fugir de outras pessoas, ele involuntariamente estará, na verdade, seguindo o caminho delas durante sua vida. Fugir não requer que se saiba o destino, mas do que se foge. O que significa que o fugitivo deve constantemente prever sua própria prisão."

"Sim," disse Timur Timurovitch, "De fato, quando eu penso no problema que terei com você, me apavoro."

Eu dei de ombros e olhei o pôster sobre sua cabeça. Aparentemente não era uma metáfora brilhante, afinal, mas meramente um auxílio para aula de medicina, talvez algo saído de um atlas anatômico. (PELEVIN: 1999, p. $32)^{70}$
\end{abstract}

Aqui começamos a tomar consciência do tipo de instituição em que Piotr se encontra, em vez de uma delegacia para interrogatório policial. Timurovitch aparece como uma racionalização (sem a "metáfora brilhante") e a perda do vermelho como símbolo predominante.

69 No original em inglês: "It was a poster, printed in the colours of the Russian flag and mounted on a large piece of cardboard, depicting a blue man with a typically Russian face. His chest had been cleaved open and the top of his skull sawn off to expose his red brain. Despite the fact that his viscera had been extracted from his abdomen and labelled with Latin numerals, the expression in his eyes seemed one of indifference, and his face appeared frozen in a calm half-smile; on the other hand, perhaps that was simply the effect created by a wide gash in his cheek, through which I could see part of his jaw and teeth as flawless as in an advertisement for German tooth powder."

70 No original em inglês: "If one tries to run away from other people, one involuntarily ends up actually following in their path throughout the course of one's life. Running away does not require knowing where one is running to, only what one is running from. Which means that one constantly has to carry before one's eyes a vision of one's own prison.'

'Yes,' said Timur Timurovich, 'Yes indeed, when I think of the trouble I'm going to have with you, it terrifies me.'

I shrugged and raised my eyes to the poster above his head. Apparently it was not a brilliant metaphor after all, merely a medical teaching aid, perhaps something taken from an anatomical atlas." 
A fuga da sociedade, para Piotr, parece ser uma escolha própria, mas ele se encontra enclausurado - até na camisa de força. A simbologia do vermelho e da metáfora se esvaindo, começamos a tomar conhecimento do tipo de ambiente em que nos encontramos (aos olhos do protagonista que narra):

"Aí está. Você pertence à geração que foi programada para viver em um
paradigma sociocultural, mas se viu vivendo e um bastante diferente. Você
está me entendendo? [...] Então o que temos é um conflito interno muito
óbvio. [...] Como eu já disse, atualmente quase todo mundo sofre com o
mesmo conflito subconsciente. O que quero é que você reconheça a
natureza dele. Sabe, o mundo ao nosso redor é refletido em nossa
consciência e então se torna objeto de nossa atividade mental. Quando
conexões estabelecidas no mundo real desmoronam, o mesmo acontece na
psique humana. E isso é acompanhado pela libertação de uma quantidade
colossal de energia psíquica no espaço em que seu ego está incluso. [...]
Mas o que realmente importa é como a energia é canalizada após a
explosão." (PELEVIN: 1999, p. $32-33)^{71}$

Podemos depreender que, enquanto um indivíduo que cessou suas ligações com o mundo externo, Piotr se enclausurou na própria mente, e 1919 começa a surgir como um devaneio. Por isso é importante retomar a ideia de que o pôster foi relido pelo próprio protagonista, de maneira que não era mais uma espécie de propaganda da razão comunista, mas uma figura anatômica.

Por um viés político, também fica evidente uma postura crítica de Pelevin em relação à configuração da Rússia após 1991 (mas também após a Revolução Russa de 1917). Isso porque a preparação para uma nova sociedade era composta por promessas sociais, políticas e econômicas que, na verdade, não foram realizadas. A propaganda - até explicitada no comercial de pasta de dente - ruiu por ser uma ficção criada para esconder a realidade.

71 No original em inglês: "There you are, you see. You belong to the very generation that was programmed for life in one socio-cultural paradigm, but has found itself living in a quite different one. Do you follow what l'm saying? [...] So what we have is a prima facie internal conflict. [...] As I've already said, nowadays almost everyone suffers from the same subconscious conflict. What I want you to do is to recognize its nature. You know, the world around us is reflected in our consciousness and then it becomes the object of our mental activity. When established connections in the real world collapse, the same thing happens in the human psyche. And this is accompanied by the release of a colossal amount of psychic energy within the enclosed space of your ego. [...] But what really matters is how the energy is channelled after the explosion." 
Já vimos algo parecido nas considerações de Genis acerca da queda do véu que cobria a realidade soviética, e cujos mecanismos de ficcionalização foram reaproveitados pelos escritores pós-soviéticos. Em contrapartida, a resistência de Piotr em aceitar essa realidade em que convive com Timurovitch - e tendo o poder de narração em primeira pessoa, o que faz dele nosso guia pelo romance - é também uma forma de mostrar que o paradigma sociocultural prometido nunca foi atingido.

A metaficção, por fim, corrobora explicitamente a proposta de Genis quando Timurovitch explica que
"A energia psíquica pode ser exteriorizada, por assim dizer, no mundo externo, empenhando-se para conseguir objetos como... bom, podemos dizer, uma jaqueta de couro ou um carro de luxo. Muitos de seus contemporâneos..."
Eu lembrei de Vorblei e dei de ombros. "Eu entendo. Por favor, pare."
"Excelente. No outro caso, por algum motivo qualquer, essa energia permanece ali dentro. Esse é o curso menos favorável de acontecimentos. Imagine um touro trancado dentro de um museu..."
"Uma imagem excelente."
"Obrigado. Então, esse museu, com suas exposições frágeis e possivelmente belas, é sua personalidade, seu mundo interior. E o touro movendo-se descontroladamente ali dentro é a libertação da energia psíquica com a qual você não conseguiu lidar. O motivo para você estar aqui." (PELEVIN: 1999, p. 33) ${ }^{72}$

Este discurso é imediatamente relacionado ao que retomamos sobre a possibilidade de construção de mundos pela ficção pós-soviética. Tratamos, entretanto, como metaficção justamente porque estamos sendo conduzidos por uma mente esquizofrênica em seus constructos mentais.

Por causa dessa relação entre a ficção psicológica criada por um caos, que é

72 No original em inglês: "Psychic energy can move outwards, so to speak, into the external world, striving towards objects like... well, shall we say, a leather jacket or a luxury automobile. Many of your contemporaries...'

I remembered Vorblei and shuddered. 'I understand. Please do not continue.'

'Excellent. In the other case, for one reason or another, this energy remains within. This is the less favourable course of events. Imagine a bull locked inside a museum...'

'An excellent image.'

'Thank you. Well then, this museum, with its fragile and possibly beautiful exhibits, is your personality, your inner world. And the bull rushing about inside it is the release of psychic energy that you are unable to cope with. The reason why you are here." 
comparado ao touro no museu, Timurovitch reproduz a proposição de Lipovetsky de que a ficção de alguns autores pós-soviéticos se identifica com a ciência do caos, cujo estudioso mais renomado é llya Prigogine (1917-2003), químico russo. Segundo Lipovetsky,

[...] o sistema caótico e desequilibrado pode se transformar ao encontrar uma ordem diferente daquela que tinha antes. [...] O paradoxo está no fato de que enquanto um sistema está dissipando energia, essa dissipação não leva à entropia, mas à formação de uma nova ordem, ou seja, de novas estruturas. [...] Essa característica é detectável no conceito de restauração da realidade, iminente [...] em algumas obras de ficção (especialmente de Pelevin), as quais são representações dessa tendência na literatura russa. (LIPOVETSKY: 2001, p. 40) ${ }^{73}$

Relendo o que diz Timurovitch, percebemos que o caos na mente de Piotr não é unicamente uma cisão destruidora, mas promove a construção de uma nova ordem a ser admitida. Portanto, essa ficção de Pelevin usa o caos a seu favor para desenvolver camadas de realidade.

Paralelamente, Lipovetsky cita Epstein, que já vimos aqui na consideração sobre o hiper, em seu ensaio sobre o que o primeiro chama de "Neobarroco" e o segundo de "Metarrealismo". O elemento neobarroco das estruturas dissipativas, do caos, é explícito no contexto de $A$ metralhadora de argila, sobretudo se considerarmos que há diferentes realidades sobrepostas e criadas no romance incluindo as do protagonista, mas também de seus companheiros detentos.

Discutindo exatamente sobre esse romance, Lipovetsky ainda reconhece que "em Pustota, Pelevin retrata uma imagem quase romântica do modernista. Aqui, o modernista era um criador genuíno, que escolheu o vazio como expressão suprema de sua liberdade" (LIPOVETSKY: 2001, p. 44) ${ }^{74}$ Aqui reiteramos que Pustota,

73 No original em inglês: "[...] the chaotic, unbalanced system "can transform itself by finding a different order from the one it had before [...] The paradox consists in the fact that while a system is dissipating energy, this dissipation does not lead toward entropy, but toward the formation of a new order, that is, of new structures'. [...] This feature is detectable in the concept of restoration of the reality imminent $[\ldots]$ in some works of fiction (Pelevin's especially) which are illustrations of this trend in Russian literature." Grifos do autor.

74 No original em inglês: "In Pustota, Pelevin depicted an almost Romantic image of the modernist. 
sobrenome de Piotr, significa vazio em russo - ou seja, não só o esvaziamento da realidade de 1991 é escolhido pelo protagonista, mas o próprio nome do romance é uma escolha do autor que reflete uma visão crítica sobre a Rússia pós-soviética.

É ainda possível considerar a loucura de Piotr como componente significativo da crítica, pois

Com o deslocamento da loucura de fora para dentro do pensamento ou, mais especificamente, da razão, com seu estatuto antropológico de outro que the é interior, o caminho para o homem verdadeiro passa, na modernidade, pelo homem louco, pelo alienado; a via de acesso à verdade natural do homem descobre no louco sua verdade profunda. (MACHADO: 2000, p. 31)

Neste estudo de Roberto Machado sobre Michel Foucault (1926-1984), o raciocínio sobre História da loucura (1961), do filósofo francês, podemos identificar que a loucura de Piotr - uma representação, segundo vimos, do autor moderno - é um fator já estudado nas pesquisas específicas sobre a loucura no século $X X$.

Ainda nessa relação, o vazio a partir do qual Piotr reconstrói a realidade de 1919 se justifica pela necessidade de uma liberdade expressa. A imagem do enclausuramento na camisa de força e da instituição psiquiátrica reverberam o fato de que

[...] é uma instituição assistencial situada entre a polícia e a justiça: uma ordem terceira da repressão, sugere Foucault, que nada tem a ver com as questões da essência da loucura e da recuperação do louco, e sim com a exclusão dos indivíduos considerados perigosos porque associais. (MACHADO: 2000, p. 17)

Portanto, é extremamente significativo o fato de Piotr estar em uma instituição desse porte, como o louco que vive no passado; por outro lado, a doença que ameaça a Rússia de 1991 também acompanha o Ocidente de Maria, o Oriente de Serdiuk e a metafísica de Volodin.

O caos incompreensível para Timurovitch, por sua vez, é a razão para que

Here, the modernist was a genuine creator, one who chose emptiness for the ultimate expression of his freedom." 
"[...] algumas pessoas se esforçam ativamente, por assim dizer, pelo novo, enquanto outras insistem em suas tentativas de esclarecer suas relações não-existentes com as sombras de um mundo desaparecido" (PELEVIN: 1999, p. 33) ${ }^{75}$ O "novo russo" ligado ao passado é, também, considerado um risco à sociedade pelas autoridades.

Todo conteúdo que acompanhamos nos sonhos dos detentos, de fato, justificamos pela história do país. A "venda" da identidade europeia, conforme vimos, é a que predominou após 1991 - portanto, corrobora o presente histórico. Por isso, o apreço pelos soviéticos, pelo Japão e por uma metafísica espiritual representa uma doença social. Não obstante, a primeira personagem que consegue sua liberdade do hospício é Maria.

Contrariamente à detenta, "Pustota não sabe qual das realidades que ele conhece são autênticas e quais são ficcionais. Mas ele escolhe por si próprio o mundo em que ele é um poeta decadente e comissário de Tchapaiev" (LIPOVETSKY: 2001, p. 44).$^{76}$ Por isso seu enclausuramento, tal qual a terminologia de Foucault, é o mesmo caminho do Homem da modernidade: a capacidade de criar realidades é marca de Pelevin, se reflete em Piotr e, por fim, implica no questionamento à sociedade que se formou após 1991.

A composição do mundo de $A$ metralhadora de argila, conforme percebemos, leva em consideração os nomes que o compõem: Maria, Schwarzenegger, Taira, Nobunaga, Tchapaiev, Pustota - todos possuem um significado para se localizar o contexto. Por outro lado, em 1991 há uma informação que terá grande relevância para entendermos o reforço à prisão atribuída ao hospício: o nome completo do

75 No original em inglês: "[...] some people actively strive, as it were, towards the new, while others persist in their attempts to clarifly their non-existent relations with the shadows of a vanished world"'

76 No original em inglês: "Pustota does not know which of the realities known to him are authentic and which are fictitious. But he chooses for himself the world where he is a decadent poet and Chapaev's Commissar." 
psiquiatra é Timur Timurovitch Kanashnikov, referência que podemos destacar à arma Kalashnikov (AK-47, famoso rifle de assalto soviético) e à "Kanachikova dacha", um dos hospícios mais famosos da Rússia (BRINTLINGER: 2004, p. 47).

Há uma evidente tríade de elementos da repressão no espaço da instituição psiquiátrica, mais uma vez trazendo Foucault à discussão - desde o enclausuramento, até o nome do psiquiatra e, por fim, a visão que acompanhamos através de Piotr de que ali seria uma instalação da Cheka. Por isso, aliás, Barbolin e Zherbunov, que antes faziam parte do aparato policial, agora são enfermeiros e as primeiras pessoas que o protagonista encontra na realidade de 1991.

Justifica-se assim o ávido desejo por liberdade que permeia a reconstrução da realidade de Piotr e, se é a partir desse vazio que a liberdade se faz possível,

\begin{abstract}
Ao comparar 1919 com os anos 1990, Pelevin parece sugerir que o início desses dois tempos é ligado por uma profunda sensação de vazio. Ele explora a persona de seu herói "vazio" tanto por interações com as personagens do "texto soviético de Tchapaiev" [...] quanto por psicoterapia. No hospício, as sessões de terapia de grupo do Dr. Kanashnikov dão aos pacientes a oportunidade de interagir com os delírios e fantasias dos outros. (BRINTLINGER: 2004, p. 53) ${ }^{77}$
\end{abstract}

Com isso, percebemos uma coerência de Pelevin no que concerne à sua resistência à vida pós-soviética, em que as identidades são "atiradas em nossa direção", e há uma interessante relação entre dois períodos aparentemente muito diferentes na história da Rússia, mas que têm em si um momento metafisicamente semelhante.

Ainda com essa ideia, a liberdade também se justifica na possibilidade de criação da nova realidade, possibilidade essa também contida no potencial de reconstrução da vida russa nos momentos de efervescência política. A Guerra Civil e

77 No original em inglês: "In comparing 1919 with the 1990s, Pelevin seems to suggest that the beginnings of both of these new eras have been linked with a profound sense of emptiness. He explores the persona of his 'empty' hero both through interactions with the characters from the Soviet 'Chapaev text' [...] and through psychotherapy. In the madhouse, Dr. Kanashnikov's group therapy sessions give the patients the opportunity to interact with each other's delusions and fantasies." 
a queda dos soviéticos são semelhantes no reconhecimento do vazio, mas, conforme vimos, a Rússia oriunda de ambos se configurou pela repressão em diversos aspectos.

É com esse panorama que podemos fundamentar o uso da esquizofrenia como alicerce da identidade do protagonista; ainda se justifica a narração em primeira pessoa, pela qual somos conduzidos às possibilidades de realidade numa Rússia novamente cindida. Assim, Piotr pode ser considerado, dentro do romance, como uma figura tanto de herói quanto como anti-herói. Apesar de isso corroborar a ideia de que "o arquétipo do herói está, desde o início, intimamente ligado ao do antiherói, o qual muitas vezes une-se ao herói, numa única pessoa" (MELETíNSKI: 1998, p. 92), o título do livro trazendo duas personagens é subordinado às realidades e possibilidades da mente de Piotr.

Essa mesma esquizofrenia, refletindo-se na cisão que observamos no histórico do país, também faz parte da construção arquetípica do herói:

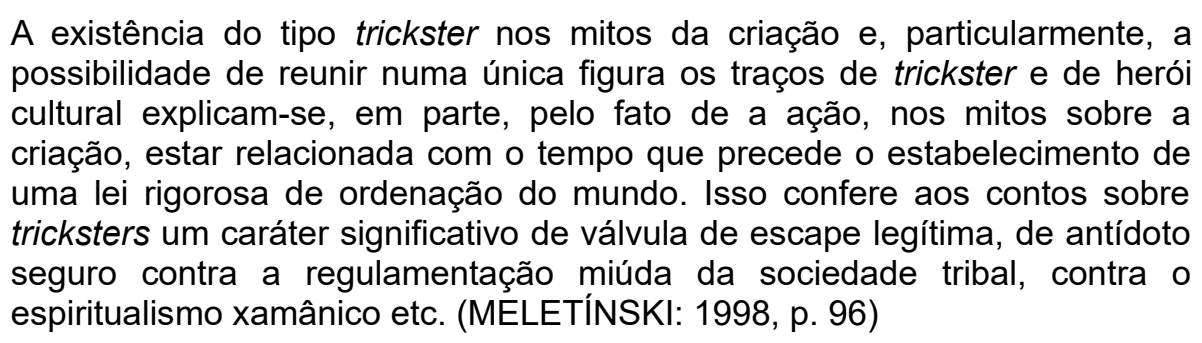

Nessa leitura de Eleazar Meletínski (1918-2005), estudioso de folclore e literatura, podemos ver uma relação intrínseca com o que observamos em $A$ metralhadora de argila: o herói que participa dos mitos de criação carrega consigo uma figura “impostora" representando a desordem.

Piotr, portanto, é um herói que se compõe tanto do caos que permite a restauração da realidade (conforme Lipovetsky), quanto do anti-herói que, utilizandose da realidade metaficcional, cria alternativas ao seu enclausuramento. O Piotr 
comissário de Tchapaiev se apresenta como a válvula de escape para um novo russo que almeja a liberdade em relação a um presente que não o atrai.

Se mantivermos a linha de raciocínio sobre herói e anti-herói dentro de Piotr, também precisamos relembrar o início do romance e a referência a Dostoievski. Ainda segundo Meletínski,

\begin{abstract}
O antiquíssimo arquétipo do duplo revela-se extremamente enriquecido. Esse enriquecimento prossegue nas obras mais tardias de Dostoievski (Raskólnikov-Svidrigáilov, Stavróguin-Verkhoviênski, Ivan KaramázovSmerdiákov, Ivan Karamázov e o diabo). Em Dostoiévski multiplicam-se de modo concomitante os tipos de duplos e alastra-se a luta de contradições na alma do homem isolado, sendo que tais contradições, esta luta do bem e do mal, permanecendo no âmbito da alma individual, possuem a tendência de crescer simultaneamente não só até atingir proporções sociais, nacionais, mas também cósmicas. (MELETíNSKI: 1998, p. 213-214)
\end{abstract}

Disto podemos concluir que Pelevin escolhe a duplicidade de Raskolnikov como fator determinante para a construção de Piotr, mas, seguindo a predileção por nomes significativos, haver cisão no conteúdo do herói dostoievskiano é relevante ao desenvolvimento do protagonista.

Com essa comparação, fica bastante evidente que nossa explicação carrega Lotman e Meletínski em direção à composição cultural que $A$ metralhadora de argila representa: esquizofrenia, Piotr e os sonhos de seus colegas são elementos absolutamente interligáveis na nossa leitura do romance. Não à toa, a cisão psicológica faz referência à divisão histórica, atingindo a proporção nacional e, no contexto de 1991, promove a crítica social do momento pós-soviético.

A escolha que Piotr faz, de aceitar a Guerra Civil como sua realidade autêntica, se dá por uma ideia de Pelevin de que, apesar do encarceramento físico, o espaço psiquiátrico é "um espaço de liberdade filosófica em contraste com as repressões encontradas no exterior" (BRINTILINGER: 2004, p. 52) ${ }^{78}$ O hospício

78 No original em inglês: "a space of philosophic freedom in contrast to the repressions to be found on the outside." 
representa um isolamento - já tratado por Meletínski - e a esquizofrenia é o que 1) justifica a personagem isolada; e 2) permite a ela que, a partir do caos psicológico, construa as realidades paralelas.

Tendo isso como plano de fundo, cabe a nós selecionar alguns episódios em que essas realidades paralelas trabalham em favor da profundidade filosófica e metafísica de A metralhadora de argila, e, especialmente, em favor de uma síntese identitária que se expressa por meio de Piotr. Tendo isso em vista, a seguir veremos momentos-chave do romance que corroboram nosso apreço por esta obra.

\title{
1. Tchapaiev e Vazio - primeiro encontro
}

Já discutimos acerca do título, no qual explicita-se uma transição observada porque

\begin{abstract}
O título original em russo, Chapaev i Pustota, já é suficiente para depreendermos uma relação construída por Pelevin: se o primeiro herói do romance é Tchapaiev, o segundo, pela tradução, é Vazio. O caminho de construção da narrativa é, então, uma transição do herói do hipermaterialismo soviético ao herói do pós-modernismo russo - o que, pelo que veremos, passa por uma espécie de "esvaziamento do real." No entanto, mais do que um embate entre as personagens do título, o importante é conseguir entender quem é o novo herói, e a razão para essa desconstrução da identidade pós-soviética. (MEYER: 2017, p. 197)
\end{abstract}

Ao primeiro encontro, já nos é apresentado o teor dos diálogos entre as personagens, com a convocação de Piotr para ser comissário de Tchapaiev numa campanha para o Leste.

Enquanto apresentam a hipnose como um aspecto reinante no mundo (p. 72), a identificação entre ambas as personagens começa a tomar força, sobretudo em uma reflexão sobre a crítica de arte:

De fato, eu havia, há muito tempo, chegado a conclusões muito similares, mas no que concerne a conversas sobre arte, as quais sempre me deprimiram com sua monotonia e falta de sentido. Desde que fui obrigado, 
em virtude de minhas atividades, a encontrar vários imbecis crônicos de círculos literários, eu cultivei deliberadamente a habilidade de participar das discussões deles sem prestar nenhuma atenção ao que estava sendo dito [...] (PELEVIN: 1999, p. 76-77) $)^{79}$

Tchapaiev e Piotr compartilharão uma visão que expressa, conforme vimos, a impressão que Pelevin tem do âmbito literário, sobretudo na necessidade que há de profundidade além do diálogo com os leitores.

Isso se dá enquanto ambos os protagonistas estão se conhecendo, e a aproximação apenas se fortalece durante o romance - especialmente por Piotr ser uma releitura intelectualizada de Petka, comissário do Tchapaiev "real". Apesar de ser um encontro que ditará a realidade "preferida" no romance, ele termina - assim como o capítulo 4 - com Piotr, sonolento, pensando:

Oh, se fosse realmente possível, tão simplesmente quanto Tchapaiev se separou desses homens, deixar para trás aquela multidão obscura de falsas identidades que vêm rasgando minha alma por tantos anos! (PELEVIN: 1999, p. 85) ${ }^{80}$

É justamente no primeiro encontro entre Tchapaiev e Pustota que observamos a voz de Pelevin sobre o contexto literário e em que se justifica sua postura para com esse mesmo contexto. De outro modo, é nesse capítulo, também, que vemos uma centelha de identificação da cisão de Piotr, reconhecendo as falsas identidades presentes.

A transição final, aliás, não é acidental: o final do terceiro capítulo possui sintomas de um autorreconhecimento; o quarto inicia no hospício, numa conversa com os outros três detentos. É nele que, primeiramente, tomamos ciência do sobrenome de Piotr:

79 No original em inglês: "Indeed, I had long before come to very similar conclusions myself, only in regard to conversations about art, which had always depressed me with their monotony and pointlessness. Since I was obliged by virtue of my activities to meet large numbers of chronic imbeciles from literary circles, I had deliberately cultivated the ability to participate in their discussions without paying any particular attention to what was being spoken about [...]"

80 No original em inglês: "Oh, if only it were possible, as simply as Chapaev had parted from these men, to leave behind me that dark crowd of false identities which had been tearing my soul apart for so many years!" 
"O caso de Piotr não é muito complicado. Em um nível estrutural, não é diferente do de Maria. Ambos se identificaram com nomes, mas a identificação de Maria é com o primeiro nome, e a de Piotr é com o sobrenome. Mas o deslocamento de Piotr é mais forte. Ele não consegue nem lembrar o próprio sobrenome. Às vezes ele se chama Fourply [nome artístico na Cheka, herdado dos documentos de Vorblei], às vezes de outra coisa."

"Então qual é meu sobrenome?" eu perguntei ansiosamente.

"Seu sobrenome é Vazio," Volodin respondeu, "e sua loucura é causada por sua negação da existência de sua própria personalidade e substituindo-a com outra, totalmente inventada." (PELEVIN: 1999, p. 89)

Essa elucidação sendo sequência do primeiro contato com Tchapaiev é, portanto, uma sinalização de que a cisão de identidade atual de Piotr é com o mundo de 1919, mas também nos traz a novidade de que é uma das muitas variações adotadas pelo protagonista.

A temporalidade transitória se concentra entre 1919 e 1991, mas Piotr pode estar internado há muito mais tempo, pois outros nomes seriam outras identidades que ele teria adotado. O sobrenome Vazio, por sua vez, tem a significância não só da crítica social da personagem pós-soviética, mas acompanha a potencialidade das identidades criáveis por Piotr. A liberdade está nas possibilidades, e não na instituição que promete a "cura" - principalmente ao sabermos que Piotr acabara de voltar da ala se isolamento (p. 91).

Durante a tardia identificação da realidade que habita, vemos Piotr numa aula de produção artística, na qual tem uma sensação de déja vu e um cartaz com letras garrafais que soletravam esquizofrenia. E, abaixo dessa imagem, havia um desenho que possuía uma linha pontilhada entre São Petersburgo e Moscou. Vemos

81 No original em inglês: "Pyotr's case isn't really very complicated. At a structural level it's no different from Maria's. Both of them have identified with names, only Maria's identification is with the first name, and Pyotr's is with the surname. But Pyotr's displacement is stronger. He can't even remember his surname. Sometimes he calls himself Fourply, sometimes something else.'

'Then what is my surname?' I asked anxiously.

'Your surname is Voyd,' Volodin replied, 'and your madness is caused by your denying the existence of your own personality and replacing it with another, totally invented one."' 
aqui, explicitamente, nossa tese justificada, como uma cisão psicológica russa entre as duas cidades que representam vertentes culturais distintas do passado do país.

Nesse desenho, aliás, havia a reprodução do cartaz do filme Chapaev (1934), dos irmãos Vasiliev, uma evidente alusão à campanha para o Leste e retomada da personagem que Piotr conhecera no sonho do capítulo anterior. Ao retrabalhar o desenho, o protagonista descreve uma sensação de desespero:

Não era meramente a questão de sua banalidade, mas de sua maldade institucional: todos envolvidos em arte repetiam isso de uma maneira ou de outra, classificando-se como membros de uma casta existente especial, mas por que? Não teria a vida de um fuzileiro ou de um médico metódico, por acaso, levado a algum outro resultado? Ou seriam eles menos preenchidos pelo tormento do absurdo? E estaria a incomensurável tragédia da existência ligada de algum modo ligada à procura que uma pessoa se empenha durante sua vida? (PELEVIN: 1999, p. 97) ${ }^{82}$

É notória a resistência de Pelevin a uma espécie de comunidade de escritores, principalmente nesses trechos que destacamos. A recusa ao tratamento como uma "casta especial" também se reflete na relação entre Piotr e Thapaiev, ligado aos camponeses russos e ao heroísmo do soldado oriundo das classes mais pobres.

Isso só é confirmado no diálogo seguinte, com Volodin:

\begin{abstract}
"Sabe, eu estava pensando... As pessoas vivem pensando na tragédia do artista, a tragédia do artista. Mas por que o artista em particular? É realmente bastante injusto. O fato é, veja, que artistas são indivíduos muito visíveis, e por isso os problemas que encontram na vida são expostos e atirados ao público... mas alguém já pensou... Bem, não, eles devem lembrar de um empreendedor... Digamos, um maquinista? Não importa quão trágica a vida dele seja?" (PELEVIN: 1999, p. 97) ${ }^{83}$
\end{abstract}

82 No original em inglês: "It was not merely a question of its banality, but of its institutional meanness: everybody involved in art repeated it in one way or another, classifying themselves as members of some special existential caste, but why? Did the life of a machine-gunner or a medical orderly, for instance, lead to any other outcome? Or were they any less filled with the torment of the absurd? And was the unfathomable tragedy of existence really linked in any way with the pursuits in which a person was engaged in their lifetime?"

83 No original em inglês: "You know, I was just thinking... People go on and on about the tragedy of the artist, the tragedy of the artist. But why the artist in particular? It is really rather unfair. The fact is, you see, that artists are very visible individuals and therefore the troubles that they encounter in life are bandied about and exposed to the public eye... but does anyone ever think about... Well, no, they might well remember an entrepreneur... Let us say, an engine-driver? No matter how tragic his life might be?'” 
Enquanto a tragédia é expressa pelas mãos do artista, Volodin replica que, na verdade, toda ela ocorre na mente de cada um (p. 98). A partir disso, dá-se o final da sessão de expressão artística, e os efeitos dos remédios injetados começam a emergir.

Com isso,

Todo este discurso sobre a mente do "Homem comum" se encaixa à nossa

consciência da realidade de 1991. A escolha por 1919 como realidade predominante,

por ser comissário de Tchapaiev, é a definitiva por Piotr neste momento do romance,

84 No original em inglês: "My three companions were obviously accustomed to such a routine and fell asleep almost as soon as they had laid down on their beds. I stretched out on my back and stared at the ceiling for a long time, savouring the state, rare for me, of an entirely empty mind, which was possibly a consequence of the morning's injection.

In fact, it would not be entirely correct to say that my mind was empty of all thoughts, for the simple reason that my consciousness, having entirely liberated itself of thought, continued nonetheless to react to external stimuli, but without reflecting upon them. And when I noticed the total absence of thoughts in my head, that in itself became already a thought about the absence of thoughts. Thus, I reasoned, a genuine absence of thoughts appeared impossible, because it cannot be recorded in any way - or one might say that it was equivalent to non-existence.

[...] I have always been astounded by one particular feature typical of people who are unaware of their own psychological processes. A person of that kind may be isolated for a long period from external stimuli, without experiencing any real needs, and then, for no apparent reason, a spontaneous psychological process suddenly arises within him which compels him to launch into a series of unpredictable actions in the external world. [...] The majority of the people are actually like that, and it is these lunatics who determine the fate of our world." 
sobretudo se considerarmos que seu isolamento compulsório é um cárcere sensível, e não apenas psicológico. Esse trecho, por sinal, visa a justificar a escolha de Piotr de fugir da ala onde dormiam para buscar informações no arquivo de Timurovitch sobre seu caso.

A descrição do histórico de isolamento social na infância, do bullying sofrido pelo sobrenome Vazio, do contato com filósofos como Hume, Berkeley e Heidegger - tudo resultava num diagnóstico que retomava o sobrenome como fonte de uma visão metafísica dos acontecimentos, além de um sentimento de superioridade em relação aos colegas por se considerar heroicamente acima deles (p. 103). Equipararse ao heroísmo da Guerra Civil, portanto, era um fator até compreensível, e o questionamento à arte, por exemplo, participa dessa leitura metafísica.

O Homem isolado de Meletínski parece-nos representado em Piotr, até pelo fato de retratar um processo de criação do mundo - no caso, psicologicamente. Vale ressaltar, enfim, que a fuga da ala com os colegas e o interesse no próprio caso psiquiátrico só ocorrem após o primeiro contato direto que acompanhamos entre Tchapaiev e Pustota, de modo que a busca pela autoconsciência se manifesta somente após tal encontro.

\section{Na casa de banho}

Funcionando de maneira complementar, o reencontro de Pustota com Tchapaiev numa casa de banho após uma batalha fundamental na Guerra Civil (na encruzilhada Lozovaya, que já fora retratada no desenho de Piotr) se inicia com estranhamento, pois ele não se lembra de ter ficado íntimo de seu comandante. 
Ambos se sentam à mesa para conversar sobre a situação da guerra, e o alcoolismo é marcante enquanto se embriagam durante a discussão.

Se no primeiro momento de união dos dois há uma percepção de concordância, de acordo com Piotr, em relação à visão de como a crítica de arte se distancia do que realmente importa, na casa de banho o embate carrega uma metafísica maior. Logo de início já há uma impressão de que "Tchapaiev não era, definitivamente, simples" (p. 135) ${ }^{85}$, o que virá a ser um prelúdio do tom que a conversa tomará.

Por exemplo, após algumas doses da bebida "moonshine", geralmente um destilado produzido ilegalmente, Tchapaiev tenta explicar sua estratégia de ataque para seu comissário:

\footnotetext{
"Ah, Petka, você sabe de que maneira eu luto? Você não tem como saber nada sobre isso! Tchapaiev usa apenas três golpes, você me entende?"

Eu assenti mecanicamente, mas estava escutando atentamente. "O primeiro golpe é onde!"

Ele bateu na mesa tão violentamente com o punho que a garrafa quase tombou.

"O segundo é quando!"

Novamente ele bateu nas bordas da mesa.

"E o terceiro é quem!" (PELEVIN: 1999, p. 137-138) ${ }^{86}$
}

É evidente que a estratégia de guerra de Tchapaiev contém mais do que apenas números e tropas a avançar no campo de batalha. Assim, corrobora a ideia de que o comandante não é "simples", e ainda confirmando o prefácio, em que se questiona a procedência do Tchapaiev de Furmanov, herói que teria atingido a glória pelo Exército Vermelho, mesmo sendo inculto.

85 No original em inglês: "Chapaev was very definitely far from simple."

86 No original em inglês: "Ah, Petka, d'you know the way I fight? You can't know anything about that! Chapaev uses only three blows, you understand me?'

I nodded mechanically, but I was listening carefully.

'The first blow is where!'

He struck the table so hard with his fist that the bottle almost toppled over.

'The second is when!'

Again he smote the boards of the table.

'And the third is who!'” 
Por conseguinte, uma das perguntas que Piotr se vê obrigado a fazer é sobre

o lado pelo qual lutam:

"Diga-me, Vasily Ivanovich, diretamente do coração. Você é um Vermelho ou um Branco?"

"Eu?" perguntou Tchapaiev, deslocando seu olhar para mim. "Você quer saber?"

Ele pegou duas cebolas da mesa e começou a limpá-las. Uma delas ele limpou até que ficasse branca, mas da outra ele removeu somente a pele externa, expondo a camada roxa avermelhada por baixo.

$[\ldots]$

"Há algo chamado mapa topográfico. E esta mesa é um mapa simplificado da consciência. Há os Vermelhos. E há os Brancos. Mas só porque temos consciência de Vermelhos e Brancos, nós assumimos alguma cor? E o que há em você que pode assumi-las?"

"Você está deliberadamente confundindo as coisas, Vasily Ivanovich. Se nós não somos Vermelhos e nem Brancos, então quem somos nós?"

"Petka, antes de tentar falar sobre questões complicadas, você deveria resolver as simples. 'Nós' é mais complicado do que 'eu', não é?"

"É," eu disse.

"O que você chama de 'eu'?"

"Claramente, eu mesmo."

"Você pode me dizer quem você é?"

"Piotr Pustota." (PELEVIN: 1999, p. 138-139) ${ }^{87}$

Pode passar despercebido, mas o reconhecimento do nome de Piotr no diálogo com

Tchapaiev é importantíssimo: é o primeiro momento em que ele cita o próprio sobrenome no contexto de 1919.

Mais do que isso: o aparecimento de Vazio na mesma conversa em que Piotr

se pergunta sobre a posição de ambos, ele e Tchapaiev, é notadamente uma pista

87 No original em inglês: "'Tell me now, Vasily Ivanovich, straight from the heart. Are you a Red or a White?'

'Me?' asked Chapaev, shifting his gaze to me. 'You want to know?'

He picked up two onions from the table and began cleaning them. One of them he cleaned until its flesh was white, but from the other he removed only the dry outer skin, exposing the reddishpurple layer underneath.

$[\ldots]$

'There are such things as topographical maps. And this table is a simplified map of consciousness. There are the Reds. And there are the Whites. But just because we're aware of Reds and Whites, do we take on any colours? And what is there in you that can take them on?'

'You are deliberately confusing things, Vasily Ivanovich. If we are not Reds and not Whites, then just who are we?'

'Petka, before you try talking about complicated questions, you should settle the simple ones. "We" is more complicated than "I", isn't it?'

'It is,' I said.

'What do you call "I"?'

'Clearly, myself.'

'Can you tell me who you are?'

'Pyotr Voyd."' O destaque do nome é de nossa autoria. 
de que compartilham a mesma consciência. Na sequência isso fica ainda mais explícito, pois explanam a dúvida sobre a identidade a partir dos golpes do comandante

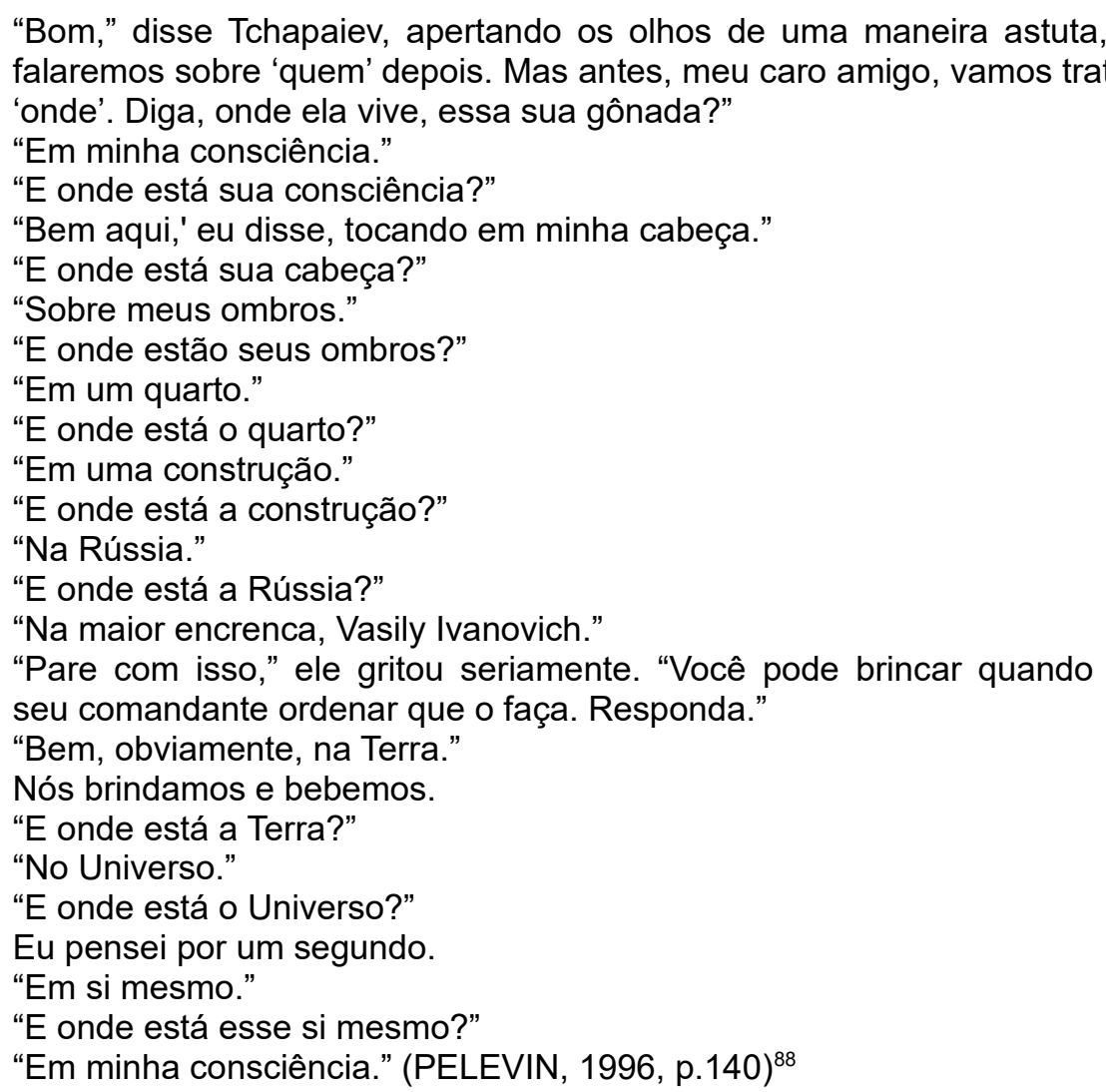

88 No original em inglês: “'Good,' said Chapaev, screwing up his eyes in a cunning fashion, 'we'll talk about "who" later. But first, my dear friend, let us deal with "where". Tell me, where's it live, this gonad of yours?'

'In my consciousness.'

'And where is your consciousness?'

'Right here,' I said, tapping myself on the head.

'And where is your head?'

'On my shoulders.'

'And where are your shoulders?'

'In a room.'

'And where is the room?'

'In a building.'

'And where is the building?'

'In Russia.'

'And where is Russia?'

'In the deepest trouble, Vasily Ivanovich.'

'Stop that,' he shouted seriously. 'You can joke when your commander orders you to. Answer.'

'Well, of course, on the Earth.'

We clinked glasses and drank.

'And where is the Earth?'

'In the Universe.'

'And where is the Universe?'

I thought for a second. 
Piotr se torna exatamente o herói criador, cuja ação psicológica edifica a Rússia em que se encontram. À pergunta sobre onde se encontra essa consciência, ainda somos provocados pela questão de que "o conceito de lugar é uma das categorias da consciência" (p. 140) ${ }^{89}$. O local onde esse conceito está encerrado também é alvo da curiosidade de Tchapaiev, mas a esta última questão Pustota desiste de responder, já que previa um ciclo de perguntas metafisicamente infinitas do seu comandante.

Neste diálogo, inclusive, podemos relembrar a questão da importância da ironia na produção de Pelevin, já comentada por Epstein, pois durante uma discussão que abarca questões sociais e espirituais, a resposta de Piotr sobre a localização da Rússia é uma quebra à pretensão de profundidade da discussão. Isso também já aconteceu antes da orgia de Serdiuk, por exemplo, quando ele assume que Kawabata é homossexual, logo após vivenciarem uma transição espiritual ao Japão medieval.

O cansaço em relação ao interrogatório faz com que Pustota peça para ficar sozinho - mais um isolamento do herói. A partir daí,

Eu comecei a pensar sobre o "lugar nenhum" e nossa conversação. À
primeira vista parecia não ser complicado: ele pediu pare responder à
questão: se eu existo por causa do mundo, ou se o mundo existe por minha
causa. Certamente, não passava de dialética banal, mas havia um aspecto
bastante assustador nisso, o qual ele apontou de modo magistral com suas
questões, à primeira vista bem estúpidas, sobre o lugar onde tudo isso
acontece. Se o mundo inteiro existe em mim, então onde eu existo? E se eu
existo neste mundo, então onde, em qual lugar no mundo, está localizada
minha consciência? (PELEVIN: 1999, p. 148-149)90

'In itself.'

'And where is this in itself?'

'In my consciousness."'

89 No original em inglês: "The concept of place is one of the categories of consciousness [...]"

90 No original em inglês: "I began thinking about this 'nowhere' and our conversation. At first glance it seemed far from complicated: he had asked me to answer the question, whether I exist because of the world, or the world exists because of me. Of course, it all amounted to nothing more than banal dialectics, but there was a rather frightening aspect to it, which he had pointed out in a masterly fashion with his questions, at first sight so idiotic, about the place where it all happens. If the entire 
Nesta reflexão, revemos a criação do mundo, parte do compromisso de Piotr enquanto herói criador e narrador do romance. Tchapaiev incentiva a criação do universo por seu comissário, sobretudo por excitá-lo a questionar tal realidade já no primeiro de seus "golpes".

Tal agitação leva Pustota a reencontrar Tchapaiev do lado de fora da casa de banho, onde tenta confrontá-lo e fazê-lo explicar o que significa o conceito de "nowhere". Ao tratar dos cavalos num estábulo vizinho dali, o plano foi perguntar "onde está este cavalo?", ao que recebe como resposta "está bem aqui na sua frente" (p. 150) ${ }^{91}$.

A resposta, tão direta e materializada à vista de Pustota, assusta o protagonista, mas também decepciona Tchapaiev, que sugere ao seu comissário que vá dormir. O retorno à casa, onde há uma cama de Piotr, é permeado pela sonolência e pela revelação de como ele vê o mundo do hospício: um pesadelo ao qual deve voltar - e, neste momento, é narrada a preparação de Serdiuk para a sessão do sonho oriental.

\section{Identidade na cera: Barão Jungern}

Antes do encontro com mais um "professor" de Piotr no romance, um encontro das lideranças do destacamento do Exército Vermelho prenuncia uma das mais profundas reflexões do romance:

Ele entrelaçou os braços no peito e apontou para a lamparina com o queixo.

world exists within me, then where do I exist? And if I exist within this world, then where, in what place in the world, is my consciousness located?"

91 No original em inglês: "“[...] where is this horse?"

[...]

'It's right here in front of your face." 
"Veja a cera," ele disse. "Observe cuidadosamente o que acontece com ela. Assim que o fogareiro esquenta, elas ascendem em gotas que assumem as formas mais fantásticas. Assim que sobem, esfriam. Quanto mais rápido sobem, mais lentamente se movem. E finalmente, em algum ponto elas param e começam a cair em direção ao lugar de onde saíram, frequentemente sem atingir a superfície."

"Há uma tragédia saída diretamente de Platão nisso," eu disse, pensativo.

"Possivelmente. Mas não é isso que tenho em mente. Imagine que as gotas solidificadas ascendendo são dotadas de consciência. Neste caso, elas irão imediatamente encontrar o problema de autoidentificação."

"Sem dúvida."

"Agora isso fica realmente interessante. Se um desses pedaços de cera acredita que essa é a forma que assumiu, então é mortal, porque aquela forma será destruída - mas se ele entender que é cera, então o que pode acontecer com ele?"

"Nada," eu respondi.

"Precisamente," disse Kotovsky. "Nesse caso, ele é imortal. Mas eis a parte complicada: é muito difícil para a cera entender que é cera - é quase impossível compreender a própria natureza primordial. Como você pode perceber o que esteve bem à sua frente desde o começo dos tempos? Então a única coisa que a cera percebe é sua forma temporária. Mas a forma é arbitrária toda vez que ascende, influenciada por milhares de circunstâncias. (PELEVIN: 1999, p. 199) ${ }^{92}$

Em tal exposição, podemos depreender que Pustota é um reflexo dessas

gotas das quais Kotovsky fala. O aquecimento é a excitação da identidade aflorando

à realidade; a lentidão nos movimentos significa um processo de assentamento; a

queda é um retorno a uma espécie de arquétipo da existência. Cada gota que se

solidifica, segundo vimos, pode ser entendida como uma expressão de uma

identidade humana, e muitas sequer atingem a superfície que é o

autorreconhecimento.

92 No original em inglês: "He folded his arms on his chest and pointed to the lamp with his chin.

'Look at that wax,' he said. 'Watch carefully what happens to it. As the spirit-stove heats up, it rises upwards in drops that assume the most fantastic forms. As it rises, it cools. The higher the pieces rise, the more slowly they move. And finally, at some point they stop and begin to fall back towards the very place from which they have just risen, often without ever reaching the surface.'

'There's a tragedy straight out of Plato in it,' I said thoughtfully.

'Possibly. But that is not what I have in mind. Imagine that the solidified drops rising upwards in the lamp are endowed with consciousness. In this case they will immediately encounter the problem of self-identification.'

'Undoubtedly.'

'Now this is where it becomes really interesting. If one of those lumps of wax believes that it is the form which it has assumed, then it is mortal, because that form will be destroyed - but if it understands that it is wax, then what can happen to it?'

'Nothing,' I replied.

'Precisely,' said Kotovsky. 'In that case it is immortal. But the tricky part is, it's very difficult for the wax to understand that it is wax - it's almost impossible to grasp one's own primordial nature. How can you notice what has been there right in front of you since the beginning of time? And so the only thing that the wax does notice is its temporary form. But the form is arbitrary every time it arises, influenced by thousands and thousands of different circumstances."' 
A proposição da queda de volta às fundações implica numa predisposição psicológica de Pustota, que sempre retorna ao seu Vazio interior antes de ascender a uma nova identidade. Quando Kotovsky responde que há algo de platônico em sua ideia, podemos relembrar a mesma "Alegoria da caverna" que vimos no sonho de Volodin: a ascensão aproxima Piotr da verdade, mas ele sempre retorna às sombras - assim que tem de se defrontar com a autoidentificação.

Quando "se torna interessante", somos compelidos a pensar nos pedaços de cera que acreditam que a forma que tomam é seu estágio final. Assumir essas formas é encarar o fato de que são efêmeras, seja na tentativa de alcançar a superfície, seja pela percepção da queda iminente. A forma que será destruída é mortal, mas a essência (cera) está além dessa destruição.

A metafísica da morte aqui exposta não só corrobora a proposição que vimos de Prigogine, sobre a transformação das realidades que supera a entropia, mas também justifica o fato de que Piotr é um caso reincidente no hospício de Timurovitch. Ao se identificar de forma efêmera, nosso protagonista carrega consigo uma mortalidade prevista no romance, pois não atinge os alicerces de sua identidade - e por isso tal realidade é questionada por seu "mestre", Tchapaiev.

Imortalizar Piotr significa uma estabilização de sua identidade, mas, segundo Kotovsky, é muito difícil a "cera" entender que o é - ou, no caso, Piotr tem uma grande dificuldade de reconhecer seu próprio eu. Por isso, a cada ascensão em direção a uma superfície (ou a cada identidade alternativa), Pustota assume esse percurso como a realidade autêntica.

Aparentemente há um tratamento realizado por Kotovsky, pois a conclusão a que chegam é: 
"[...] o único caminho para a imortalidade para uma gota de cera é parar de pensar em si mesma como uma gota e perceber que é cera. Mas uma vez que essa gota é apenas capaz de perceber sua própria forma, durante toda sua breve vida ela reza para o Deus Cera para preservar sua forma, embora, se alguém pensar sobre isso, essa forma não possui nenhuma relação inerente com a cera. Toda gota de cera possui exatamente as mesmas propriedades de seu volume total. Você me entende? Uma gota do grande oceano do ser é o oceano inteiro, contraído por um momento à extensão dessa gota. Mas então me diga, como explicar isso para essas gotas de cera que temem, mais do que tudo, por suas próprias formas efêmeras?" (PELEVIN: 1999, p. 200) ${ }^{93}$

Reverbera no discurso de Kotovsky a voz de Timurovitch, em uma tentativa de atingir o âmago da cisão identitária de Piotr, e, por fim, tentando trazê-lo à unidade, em vez das "gotas".

Reconhecer a unidade psicológica de Pustota significa levá-lo das diversas ascensões em direção à superfície rumo a um reconhecimento de sua essência enquanto indivíduo. As alternativas que Piotr aceita como reais são, portanto, apenas breves delírios de personalidade que suprem sua necessidade de criar um mundo em que se adapte - o herói criador de Meletínski sendo submetido à esquizofrenia do protagonista.

Repentinamente, a imagem se modifica com a lamparina explodindo por um tiro de Tchapaiev, que começa a questionar Kotovsky:

\footnotetext{
"A forma, a cera - quem criou tudo isso?" Tchapaiev perguntou ameaçadoramente. "Responda!"

"A mente," respondeu Kotovsky.

"Onde ela está? Mostre."

"A mente é a lamparina," disse Kotovsky. "Quer dizer, era..."

"Se a mente é a lamparina, então para onde você vai agora que está quebrada?"

"Então o que é a mente?" Kotovsky perguntou, confuso.

Tchapaiev deu outro tiro, e a bala transformou o tinteiro sobre a mesa em uma nuvem de fumaça azul.

Eu senti uma estranha tontura momentânea. (PELEVIN: 1999, p. 201) $)^{94}$
}

93 No original em inglês: "[...] the only route to immortality for a drop of wax is to stop thinking of itself as a drop and to realize that it is wax. But since our drop is capable only of noticing its own form, all its brief life it prays to the Wax God to preserve this form, although, if one thinks about it, this form possesses absolutely no inherent relation to the wax. Any drop of wax possesses exactly the same properties as its entire volume. Do you understand me? A drop of the great ocean of being is the entire ocean, contracted for a moment to the scope of that drop. But now, tell me how to explain this to these drops of wax that fear most of all for their own fleeting form?"

94 No original em inglês: 'The form, the wax - who created it all?' Chapaev asked menacingly. 
A interrupção de Tchapaiev à explicação de Kotovsky reflete a predisposição do comandante em relação à realidade do mundo, pois a mente faz parte da destrutibilidade dessa existência.

O tiro e a destruição da forma da lamparina de certa forma libertam a mente à qual Kotovsky se referia, mas o que mais interessa é a nuvem após o segundo tiro: essa "expansão" do conteúdo interno, seja da tinta, seja da cera, implica na superação do recipiente. A lamparina e o tinteiro, por sua vez, são, tal qual na exposição de Kotovsky, as próprias formas que limitam a transcendência das gotas a se limitarem em si, e não reconhecerem sua verdadeira essência. A tontura de Piotr, ao final dessa cena, será importante após o encontro com Barão Jungern, para onde ele e Tchapaiev partem após o entrevero que reproduzimos.

No caminho para a conversa com o Barão, retomam os questionamentos sobre o "pesadelo" de 1919:

\footnotetext{
"Você mesmo me disse que nos seus pesadelos tudo muda em uma velocidade fantástica. Qualquer atividade consistente à qual você retorna repetidamente torna possível criar algo como um centro fixo ao sonho. Então o sonho se torna mais real. Você não poderia pensar em uma ideia melhor do que tomar notas em seu sonho."

Eu ponderei a ideia.

"Mas que bem tem um centro físico no meu pesadelo, se o que eu realmente quero é me livrar dele?"

"É precisamente para se livrar dele - você só pode se livrar de algo que é real."

[...]

"Eles são quase impossíveis de esquecer," eu disse. "Toda vez que volto a mim, percebo que não era nada além de um pesadelo... Mas enquanto eu estou dormindo, é impossível de entender o que é real de fato - a carruagem onde estamos sentados agora ou o inferno de azulejos brancos
}

\footnotetext{
'Answer me!'

'Mind,' replied Kotovsky.

'Where is it? Show me.

'Mind is the lamp,' said Kotovsky. 'I mean, it was.'

'If mind is the lamp, then where do you go to now it's broken?'

'Then what is mind?' Kotovsky asked in confusion.

Chapaev fired another shot, and the bullet transformed the ink-well standing on the table into a cloud of blue spray.

I felt a strange momentary dizziness."
} 
onde demônios em jalecos brancos me torturam toda noite." (PELEVIN: 1999, p. 204-205) $)^{95}$

Tchapaiev indica a seu comissário que tome notas para que Piotr tenha um ponto fixo em seu pesadelo, da mesma maneira que Timurovitch incentiva seu paciente a representar o sonho de 1919 por meio da expressão artística. Em ambos os momentos, a criação desse ponto aproxima Pustota de algo mais real.

Podemos, inclusive, supor que essa fixação das realidades faz parte do segundo golpe de Tchapaiev - o "quando" -, tendo em vista que os dois mundos são separados, principalmente, por uma noção de tempo, de momentos de transição diferentes na história da Rússia. Ainda resta o terceiro golpe, "quem", que surgirá no final do romance.

Por fim, ao chegarem ao acampamento onde se encontra o Barão, vemos pela primeira vez uma figura que Tchapaiev não comanda. $\mathrm{O}$ tom inicial entre o comandante e Jungern é de respeito, mas o que chama a atenção é Tchapaiev levar "um novo pedido" (p. 211), de maneira que entendemos a figura de poder que ali se encontra.

Vale frisar que o Barão Jungern de Pelevin é uma referência a Roman Ungern von Sternberg (1886-1921), um dos líderes do Movimento Branco após a Revolução de 1917 e que lutou contra os bolcheviques. Em A metralhadora de argila, portanto, estão as duas frentes da Guerra Civil, mas elevando-se além da batalha - o grande

95 No original em inglês: "You told me yourself that in your nightmares everything changes with fantastic speed. Any consistent activity that you repeatedly comes back to makes it possible to create something like a fixed centre to the dream. Then the dream becomes more real. You couldn't possibly think up any better idea than making notes in your dream.'

I pondered the idea.

'But what good is a fixed centre to my nightmares if what I really want is to get rid of them?'

'It's precisely in order to get rid of them - you can only get rid of something that is real.'

$[\ldots]$

'They are quite impossible to forget,' I said. 'Every time I come round, I realize that it was no more than a nightmare... But while l'm dreaming, it's impossible to understand what is real in actual fact - the carriage we are sitting in or that white-tiled hell where demons in white coats torment me at night."” 
herói do Exército Vermelho e o líder dos Brancos como "colegas" em busca da libertação de Piotr.

A descrição de Jungern como "guardião da Mongólia Interior" e "encarnação do deus da guerra" (p. 210) nos leva à união de ambos os professores que Pustota terá no sonho de 1919, associando a campanha para o Leste de Tchapaiev e o senhor da guerra na Mongólia. O segundo, por sinal, era conhecido por um apreço ao Budismo, ao passo que o primeiro, conforme Pelevin o constrói, parece sair em defesa da conquista do nirvana - ambos carregam consigo uma espiritualidade que reverbera o autor no romance.

É interessante perceber que, segundo essa relação construída por Pelevin, a relação da guerra com a libertação é intrínseca: parece que apenas após a destruição do mundo interior pode-se haver liberdade. A batalha entre Piotr e os "demônios de jaleco branco" retoma as duas cebolas de Tchapaiev, mas, mais do que isso, coloca Piotr novamente ao lado de seu comandante, "contra os brancos"; por outro lado, o momento do encontro com Jungern acontece justamente quando ele já reconhece o próprio nome no mundo de 1991, e já se lembra de diversos acontecimentos ali ocorridos, os quais chama de pesadelos.

A aproximação do centro fixo dos sonhos inclui um autorreconhecimento, mas também uma menor resistência aos Brancos - ou seja, ao mundo do pesadelo. A batalha entre eles e os Vermelhos é, na verdade, uma grande "guerra civil interna" em Pustota, por isso o uso de tal evento histórico na Rússia é absolutamente coerente. Do mesmo modo, as cebolas começam a ser explicadas: na superfície avermelhada, o protagonista se sente confortável e a aceita; entretanto, por dentro, ao tirarmos as camadas [de realidade], seu mundo é o branco, onde está internado. 
Por isso, o encontro mais significativo no que concerne ao entendimento da realidade é o com o Barão Jungern, no qual Pustota terá de enfrentar a ideia de que os Brancos não são inimigos, mas parte dele também. É por isso que, ao entrarem na barraca do Barão,

Devo confessar que estava com medo. Não é que eu sentia alguma ameaça real de perigo a mim - ou melhor, era precisamente uma sensação de perigo, mas não do tipo que se sente antes de um duelo ou uma batalha, quando você sabe que o que há de pior pode acontecer apenas a você. Naquele momento eu tinha a sensação de que o perigo não estava me ameaçando, mas minha própria concepção de mim mesmo. Eu não estava esperando que nada de terrível acontecesse, mas o "eu" que não estava esperando nada de terrível de repente me parecia um homem andando em uma corda sobre um abismo, e que acabara de sentir o primeiro sopro de uma brisa surgindo. (PELEVIN: 1999, p. 213) ${ }^{96}$

Nesse momento, Pustota sente que sua realidade presente está prestes a se desfazer, tendo também a impressão de que os pesadelos são, na verdade, uma realidade possível. O temor se justifica porque, apesar de reconhecer a possibilidade de outra existência, é nela que se sente torturado e preso - 1919 surge como um constructo da liberdade para ele, uma fuga semelhante à abertura do "cofre" de Volodin.

É por esse motivo, inclusive, que, ao entrarem na barraca do Barão, o que Piotr vê é um espaço imenso e envolto na escuridão, interrompida apenas por algumas fogueiras. Tal lugar, segundo Jungern, é "um dos ramos do mundo alémtúmulo" (p. 214) ${ }^{97}$, pelo qual ele é responsável - e, depois, nomeia-o como Valhalla, o salão dos mortos da mitologia nórdica, para o qual iam guerreiros dignos de lutar ao lado do deus Odin.

96 No original em inglês: "I must confess that I was afraid. It was not that I felt any real threat of danger hanging over me - or rather, it was precisely a sense of danger, but not of the kind felt before a duel or a battle, when you know that even the very worst that can happen can only happen to you. At that moment I had the feeling that the danger was not threatening me, but my very conception of myself. I was not expecting anything terrible to happen, but the 'l' who was not expecting anything terrible suddenly seemed to me like a man walking a tightrope across an abyss who has just sensed the first breath of a burgeoning breeze."

97 No original em inglês: "“...] one of the branches of the world beyond the grave"' 
O interessante é a mudança de leitura que Jungern faz sobre Valhalla: apesar de haver guerreiros honrados, há diversas pessoas que encontram-se ali apenas por terem matado, como bandidos e assassinos. Essa visão irônica de Valhalla é parte do humor literário de Pelevin, visível também na remodelagem de Tchapaiev neste romance, por exemplo.

Por outro lado, a ideia de reencarnação, seja para lutar ao lado de Odin, seja pela ideia de retorno budista, ainda se faz presente: ao se aproximarem de uma das fogueiras, Jungern conversa com dois homens ali perdidos. Recebendo a explicação sobre a presença deles,

Ele se debruçou e assoprou as chamas, que imediatamente encolheram a uma fração de seu tamanho, mudando de uma tocha inflamada para uma chama pálida com poucos centímetros de altura. O efeito que isso produziu nos dois homens seminus foi espantoso - eles enrijeceram em completa imobilidade, e suas costas foram instantaneamente cobertas por gelo.

"Guerreiros, é?" disse o barão. "O que você acha disso? As pessoas que chegam a Valhalla esses dias. Seryozha, o Mongolóide... É culpa daquela estúpida regra sobre ter uma espada em suas mãos."

"O que aconteceu com eles?" eu perguntei.

"O que deveria acontecer," disse o barão. "Eu não sei. Mas posso dar uma olhada."

Ele assoprou novamente na quase invisível chama azul e ela queimou com sua antiga energia. O barão olhou para ela por vários segundos com seus olhos semicerrados.

"Parece que eles serão touros em um complexo de produção de carne. Esse tipo de indulgência é comum hoje em dia, em parte pela infinita misericórdia do Buda, em parte pela crônica falta de carne na Rússia." (PELEVIN: 1999, p. 216) ${ }^{98}$

98 No original em inglês: "He leant down and breathed on the flame, which immediately shrank to a fraction of its size, changing from a hot roaring torch into a pale tongue only a few inches in height. The effect this produced on the two half-naked men was astounding - they stiffened into complete immobility, and their backs were instantly covered in hoarfrost.

'Warriors, eh?' said the baron. 'How do you like that? The people who find their way into Valhalla these days. Seryozha the Mongoloid... It's that stupid rule about having a sword in your hand that's to blame.'

'What has happened to them?' I asked.

'Whatever was supposed to happen,' said the baron. 'I don't know. But I can take a look.'

He blew once again on the barely visible blue flame and it flared up with its old energy. The baron stared into it for several seconds with his eyes half-closed.

'It seems likely they will be bulls in a meat-production complex. That kind of indulgence is rather common nowadays, partly because of the infinite mercy of the Buddha, and partly because of the chronic shortage of meat in Russia."' 
É evidente a relação com o Budismo e uma espécie de explicação da reencarnação por parte de Pelevin, ainda que se utilizando de seu humor peculiar.

Após essa demonstração, passamos ao momento-chave do encontro: Jungern pergunta a Pustota o que ele mais quer na vida. A resposta é elucidativa: "encontrar minha alegria suprema [...] [que] é quando uma fuga particular de pensamento livre torna possível ver a beleza da vida." (p. 219 $)^{99}$

O desejo de liberdade é explicitamente o que Piotr almeja, mas mesmo no mundo em que se encontram agora apresenta uma prisão - sobretudo quando dorme, e retorna sempre ao pesadelo. A fuga é tal qual a chave para se abrir o cofre de Volodin, o álcool para Serdiuk e o noivo para Maria. Complementando, Jungern ainda se interessa por como Piotr chegou a esse desejo tão direto.

"Ele vem do meu sonho," eu respondi, "ou melhor, do meu pesadelo. Eu lembrei dessa frase estranha de cor porque estava escrita em um caderno [o arquivo do caso de Piotr Pustota] de um sanatório, o qual eu estava folheando durante o sonho - eu estava folheando porque devia haver algo muito importante sobre mim ali."

"Sim, [...] estou feliz que você mencionou isso por conta própria. [...] Mas por alguma razão você ainda parece achar que o mundo de seus sonhos é menos real do que o espaço no qual você ficou bêbado com Tchapaiev na casa de banho. [...] Mas então como você distingue seu sonho do mundo desperto?" o barão interrompeu.

"Pelo fato de que quando estou acordado eu tenho uma sensação clara e inequívoca do que está acontecendo. Como tenho agora."

[...]

"Tchapaiev me pediu para te levar comigo para que, pelo menos por um momento, você se encontrasse num lugar que não tem absolutamente nenhuma relação nem com seu pesadelo sobre o sanatório, nem com seu pesadelo sobre Tchapaiev," disse o barão. "Olhe ao seu redor - ambos os seus sonhos obsessivos são igualmente ilusórios aqui. Tudo que preciso fazer é te deixar perto de uma das fogueiras e você entenderá o que quero dizer." (PELEVIN: 1999, p. 219-220)

99 No original em inglês: "[...] to find my golden joy [...] is when a peculiar flight of free thought makes it possible to see the beauty of life."

100 No original em inglês: "'It comes from my dream,' I replied, 'or rather, from my nightmare. I remembered the strange phrase by heart because it was written in a notebook from a mental home which I was leafing through in the dream - I was leafing through it because there was supposed to be something very important about me in there.'

'Yes, [...] l'm very glad that you mentioned this yourself. [...] But for some reason you still seem to think that the world of your dreams is less real than the space in which you get drunk with Chapaev in the bathhouse. [...] But then how do you distinguish your dream from the waking world?' the baron interrupted.

'By the fact that when I am awake I have a clear and unambiguous sense of the reality of what is 
Temos aqui alguns elementos curiosos sobre a construção dos mundos por Piotr: o primeiro, sem dúvida, é a lembrança que ele tem sobre o arquivo com seu histórico, inclusive lembrando de cabeça de frases significativas sobre liberdade; o segundo, reconhecendo no próprio Jungern, a quem Tchapaiev leva Piotr, uma resistência ao mundo em que se encontram; um terceiro aspecto que podemos destacar é a ideia de ausência de ambiguidade - Pustota sempre é confrontado por um duplo, seja Vorblei, seja Tchapaiev, seja Jungern, mas também há a dupla na batalha entre Vermelhos e Brancos, e a dualidade de realidades entre 1919 e o pesadelo em 1991. Por fim, o mais interessante dos pontos a salientar é a primeira referência a Tchapaiev como um pesadelo, ao que, inclusive, Piotr não responde nada.

Quando ele toma consciência de que está num ambiente externo às duas realidades, percebe que viveu numa ilusão dupla - portanto ambígua -, ou, conforme Tchapaiev diz na carruagem: "caiu de um sonho ao outro. Você ficou migrando de lá para cá desse jeito por toda a eternidade" (p. 206) ${ }^{101}$. Apesar da resistência de Piotr, ele transita entre as realidades que se apresentam, mesmo que prefira existir no momento da carruagem.

É nesse instante de revelação que Jungern e Pustota são interrompidos, e há uma combinação entre as realidades: surge uma fogueira com três pessoas ao redor, a transcendência de Kolian e Volodin olhando aterrorizado para Jungern, que

happening. As I have now.'

$[\ldots]$

'Chapaev asked me to take you with me so that for once at least you would find yourself in a place which has absolutely no relationship either to your nightmare about the mental home or to your nightmares about Chapaev,' said the baron. 'Take a good look around you - both of your obsessive dreams are equally illusory here. All I have to do is leave you by one of the camp-fires and you will understand what I mean."

101 No original em inglês: “'[...] drop from one dream into another. You've been flitting to and fro like that all eternity." 
destrói a fogueira com uma granada. A evidência de que se tratava do sonho de Volodin, aliás, está na explicação do barão de que estavam "chapados com cogumelos xamânicos" (p. 222).

Por fim, o final do passeio por Valhalla é uma elucidação sobre o "lugar" metafísico da Mongólia Interior: as pessoas estão sentadas em cadeiras e bancos, lutando para se manter em seus lugares ou até para tomar o lugar do outro -

"Esse é o mundo em que você vive. Simultaneamente, cada uma dessas pessoas possui um imenso e brilhante trono próprio, um trono elevado sobre este mundo e sobre todo os mundos que existem. Esse é um trono régio, e nada está além do poder da pessoa que ascende a ele. Ele pertence a todos por direito. Mas é quase impossível ascender a ele, porque ele se encontra em um lugar que não existe. Você entende? É o lugar nenhum. [...] Agora pense no seguinte," o barão continuou. "Aqui, como eu já disse, ambos os seus estados obsessivos - com Tchapaiev e sem ele - são igualmente ilusórios. Para atingir o 'lugar nenhum' e ascender ao trono de eterna liberdade e felicidade, você deve remover a única dimensão que ainda perdura - aquela, portanto, em que você nos vê. É o que meus guardas estão tentando. Mas as chances deles são pequenas, e após um curto período eles são obrigados a repetir o exaustivo ciclo da existência. Por que você, no entanto, não encontra para si esse 'lugar nenhum' enquanto ainda está vivo? Eu juro que isso é o melhor que você pode fazer com sua vida. Sem dúvida você aprecia metáforas - você poderia comparar isso à sua libertação do sanatório." (PELEVIN: 1999, p. 223)

Essa intrigante explicação sobre a existência mundana, atrelada a um mundo superior que devemos alcançar para nos vermos livres, relembra não só o nirvana budista, mas também o que Pelevin diz sobre o poder de se fechar em si próprio durante o período soviético. Enquanto o mundo externo representa a repressão, a

102 No original em inglês: "'Such is the world in which you live. Simultaneously, every one of these individuals has an immense, shining throne of his own, a throne towering up above this world and all the other worlds that exist. This is a truly regal throne, and nothing lies beyond the power of the person who ascends it. And, most important of all, this throne is entirely legitimate. It belongs to everyone by right. But it is almost impossible to ascend it, because it stands in a place that does not exist. Do you understand? It is nowhere. [...] Then think about the following,' the baron went on. 'Here, as I have already said, both of your obsessive states - with Chapaev and without him are equally illusory. In order to reach "nowhere" and ascend that throne of eternal freedom and happiness, it is enough to remove the single dimension which still remains - the one, that is, in which you see me and yourself. Which is what my own wards are attempting to do. But their chances are very slim, and after a certain period of time they are obliged to repeat the weary round of existence. Why should you, however, not find yourself in this "nowhere" while you are still alive? I swear to you that is the very best thing you could possibly do with your life. No doubt you are fond of metaphors - you could compare this to discharging yourself from the mental home." 
luta pelo lugar e pelo espaço dos outros, a ascensão ao "trono" representa uma afirmação do indivíduo sobre os elementos repressivos.

Pelevin não só usa Jungern como porta-voz de sua ideologia da libertação do indivíduo, mas corrobora a doutrina budista de uma elevação espiritual por sobre as realidades já estabelecidas. "Os trabalhos anteriores de Pelevin eram focados na busca desesperada por liberdade pelo isolamento de todas as formas de poder e intenções de poder, ou outras palavras, em um vazio abençoado" (LIPOVETSKY: 2001, p. 46) ${ }^{103}$. O sobrenome Pustota para o protagonista é uma escolha primorosa para construir, em A metralhadora de argila, uma narrativa de libertação.

Por isso Piotr prefere 1919, já que participa da Guerra Civil e passa a ser uma personagem importante nesse episódio da história da Rússia. O hospício de 1991 está sempre atrelado ao enclausuramento, inclusive coletivo, no compartilhamento com outros detentos, e um impedimento ao isolamento. Analogamente, isso corrobora a impressão de Pelevin na entrevista que vimos: nos anos soviéticos, era possível o isolamento mental; em 1991, no hospício, Piotr é impedido de ficar sozinho, de dormir, e deve vivenciar realidades de outros pacientes, além de precisar externalizar sua ficção psicológica.

A percepção última da ilusão que vinha alimentando durante todo o romance acontece quando Piotr deve sair da cabana do Barão:

Eu parei mecanicamente, e sem me dar um momento para compreender o
que ele estava fazendo, o barão me deu um empurrão súbito nas costas.
Desta vez, entretanto, ele não me pegou desprevenido. Durante o momento
em que meu corpo estava caindo, eu fui de algum modo capaz de reter
minha consciência daquele instante quase imperceptível de retorno ao
mundo habitual - ou melhor, já que na realidade não havia nada do que ter
consciência, eu consegui compreender a natureza desse retorno. Não sei
como descrevê-lo; era como se uma imagem de cenário fosse movida para
o lado e a seguinte não fosse colocada no lugar imediatamente, mas por um

103 No original em inglês: "Pelevin's previous works are focused on the desperate search for freedom through isolation from all forms of power and all intentions to power, in other words, in blessed emptiness." 
segundo eu olhei para o vão entre elas. E esse segundo foi suficiente para perceber a desilusão atrás do que eu sempre tomei por realidade, para perceber a maneira simples e estúpida com que o Universo foi organizado. Foi um enfrentamento que me deixou cheio de confusão, incômodo e uma certa sensação de vergonha de mim mesmo. (PELEVIN: 1999, p. 226) ${ }^{104}$

A percepção da irrealidade se dá de maneira metaficcional, de maneira que a transição entre Valhalla e 1919 é também uma queda de um sonho ao outro. Piotr demonstra uma decepção com a provada inexistência de sua realidade preferida, numa tocante reação ao esvaziamento de sentido que experimenta nessa queda.

Consequentemente, quando pergunta sobre "como se pode ver o vazio", o barão responde "apenas olhe para dentro de si" (p. 234). O trocadilho com o nome não é acidental - pelo contrário, o vazio do protagonista compreende a eterna migração entre sonhos e, portanto, o eterno vazio de realidade em que sempre viveu.

Quando devem se despedir, o evento final é uma retomada de componentes

que já vimos:

\begin{abstract}
Ele colocou a sua outra mão no bolso e pegou o pacote que Tchapaiev dera a ele. Ele desembrulhou e me mostrou um tinteiro comum com uma tampa preta.

[...] ele arremessou o tinteiro para o alto e quando ele estava a quase dois metros de nós, ele atirou.

O tinteiro se transformou em uma nuvem de fumaça azul e pequenos fragmentos que flutuaram no ar por um momento antes de se espalharem pela mesa.

Eu cambaleei para trás, e para não cair por causa da minha tontura repentina, me apoiei na parede com uma mão. Eu olhava uma mesa com um mapa irremediavelmente manchado, atrás da qual estava Kotovsky, boquiaberto. (PELEVIN: 1999, p. 236) ${ }^{105}$
\end{abstract}

104 No original em inglês: "I stopped mechanically, and without giving me a moment to grasp what he was doing, the baron gave me a sudden shove from behind.

This time, however, he did not catch me completely unaware. During the moment when my body was falling to the ground, I was somehow able to retain my awareness of that imperceptibly short instant of return to the usual world - or rather, since in reality there was absolutely nothing of which to be aware, I managed to grasp the nature of this return. I do not know how to describe it; it was as though one set of scenery was moved aside and the next was not set in its place immediately, but for an entire second I stared into the gap between them. And this second was enough to perceive the deception behind what I had always taken for reality, to perceive the simple and stupid way in which the Universe was arranged. It was an encounter which left me filled with confusion, annoyance and a certain sense of shame for myself."

105 No original em inglês: "He thrust his other hand into his pocket and took out the package which Chapaev had given him. He unwrapped it and showed me a perfectly ordinary ink-well with a black 
Este salto de um sonho ao outro, por sinal, é concentrado no tiro no tinteiro, algo como o centro fixo que une as duas realidades, seguindo a terminologia de Tchapaiev. Não apenas há a teoria de cada "professor" de Piotr, mas na ação posterior evidenciam-se essas ideias - outro exemplo seria Volodin aparecendo em Valhalla.

Portanto, o encontro com Jungern é precedido pela alegoria da cera de Kotovsky, que nos provoca a entender Pustota como sendo apenas uma das "gotas de cera"; na sequência, o Barão incentiva o próprio Pustota a reconhecer o fator ilusório por trás do mundo que reconhece como real. E, num terceiro momento, os saltos de uma realidade parecem a voz de Pelevin nos indicando uma leitura metafísica sobre o vão entre os mundos que aceitamos como autênticos.

\section{O uso da metralhadora}

Jungern já nos deu um indício das possibilidades que viriam a acontecer: quando ele falou sobre seus homens, que trabalham para desconstruir o mundo em que se encontrava com Piotr, remete-se à Guerra Civil, na qual os Brancos seguirão os Vermelhos num levante. Isso acontece no penúltimo capítulo do romance, quando Tchapaiev, Anna (sobrinha do comandante) e Pustota precisam fugir da cidade (neutra) onde estavam sediados por causa de uma revolta.

\footnotetext{
stopper.

[...] he tossed the ink-well into the air and when it was about two yards away from us, he fired.

The ink-well was transformed into a cloud of blue spray and minute fragments which hung in the air for a moment before scattering across the table.

I staggered backwards, and in order to avoid falling from my sudden dizziness, I braced myself against the wall with one hand. I was facing a table covered with a hopelessly stained map, beside which Kotovsky was standing, his mouth wide open."
} 
A fuga se dá num carro blindado, que possui uma metralhadora coberta sobre si. Quando se veem cercados pelo levante que os seguiu, Anna se posiciona para atirar com a arma, enquanto Piotr observa por um buraco a chegada dos revoltosos. Estes, por sua vez, começam a atirar no veículo, e, ao acertarem uma lâmpada, soaram um grito exultante.

Em resposta, Tchapaiev parece conformado com a situação, então diz que "tudo chega a um fim em algum momento" (p. 305). Anna se ajeita no assento, retira cuidadosamente a capa que cobria a metralhadora e, enfim, atira furiosamente, girando a arma sobre seu eixo. O efeito silencioso surpreende Piotr, mas o resultado fora satisfatório.

Diante dessa surpresa do protagonista, então, finalmente é explicado o título escolhido para a versão britânica do romance, e a importância dessa metralhadora:

\begin{abstract}
"Essa foi a metralhadora de argila," disse Tchapaiev. "Agora eu posso te dizer o que ela é. Não é uma metralhadora, na verdade. Simplesmente, vários milênios atrás, bem antes do Buda Dipankara e o Buda Shakyamuni virem ao mundo, vivia o Buda Anagama. Ele não perdia tempo com explicações, ele simplesmente apontava para as coisas com o dedinho de sua mão esquerda e a verdadeira natureza delas era revelada. Quando ele apontou para uma montanha, ela sumiu; quando ele apontou para um rio, ele desapareceu também. É uma longa história, mas em resumo tudo terminou com ele apontado para si mesmo com seu dedinho e então desaparecendo. Tudo que sobrou dele foi aquele dedinho de sua mão esquerda, o qual seus discípulos esconderam em um pedaço de argila. A metralhadora de argila é aquele pedaço de argila com o dedo do Buda escondido nela. (PELEVIN: 1999, p. 305)
\end{abstract}

Com essa explicação, também fica óbvia a escolha, na versão estadunidense, do título Buddha's little finger, pois tanto a metralhadora quanto o dedinho são as justificativas do conceito de essência que permeia a narrativa.

106 No original em inglês: “'That was the clay machine-gun,' said Chapaev. 'Now I can tell you what it is. It isn't really a machine-gun at all. It's simply that many millennia ago, long before the Buddha Dipankara and the Buddha Shakyamuni came into the world, there lived the Buddha Anagama. He didn't waste any time on explanations, he simply pointed at things with the little finger of his left hand, and their true nature was instantly revealed. When he pointed to a mountain, it disappeared, when he pointed to a river, that disappeared too. It's a long story, but in short it all ended with him pointing to himself with his little finger and then disappearing. All that was left of him was that finger from his left hand, which his disciples hid in a lump of clay. The clay machine-gun is that lump of clay with the Buddha's finger concealed within it."' 
É notável que o mundo ao redor tenha sido destruído, mostrando sucesso da proposta de Jungern e da metralhadora. O pequeno círculo que restou representava o raio de ação da arma; por fim, Anna pega um espelho e aponta de volta para a metralhadora, o que faz o carro sumir - "e agora não havia nada para atrapalhar o silêncio" (p. 307) $)^{107}$.

O resultado desse uso é explicitado por Tchapaiev, quando diz que o mundo que conheciam já não existe mais (p. 307). Em seguida, à confusão de Piotr quanto ao que farão depois de tal destruição, o comandante explica:

\footnotetext{
"Ah, Petka, Petka," disse Tchapaiev. "Eu vivo tentando explicar pra você. Qualquer forma é apenas vazio. Mas o que isso significa?"

"Bem, o que?"

"Significa que o vazio é qualquer forma. Feche seus olhos. Agora abra-os."

Eu não sei como descrever aquele momento em palavras.

$\mathrm{O}$ que eu vi era algo similar a uma corrente fluindo que brilhava com todas as cores do arco-íris, um rio grande além de qualquer medida, e que fluía de algum lugar perdido na infinitude em direção àquela mesma infinitude. [...] Para ser mais preciso, a corrente com tons do arco-íris era tudo que eu poderia pensar de experiência, tudo que eu poderia ser ou não ser, e eu sabia, com certeza, que não era algo separado de mim. Era eu, e eu era ela, o que sempre fui e nada mais.

"O que é isso?" eu perguntei.

"Não, não nesse sentido," eu disse. "Como é chamado?"

"Tem vários nomes," Tchapaiev respondeu. "Eu chamo de Undefinable River of Absolute Love [Rio Indefinível do Amor Absoluto]. Ural na versão curta. Às vezes nos tornamos ele, e às vezes assumimos formas, mas, na verdade, nem as formas, nem nós mesmos, nem o próprio Ural existe." (PELEVIN: 1999, p. 308-309) $)^{108}$
}

107 No original em inglês: "And now there was nothing to disturb the silence."

108 No original em inglês: “'Ah, Petka, Petka,' said Chapaev. 'I keep on trying to explain to you. Any form is just emptiness. But what does that mean?'

'Well, what?'

'It means that emptiness is any form. Close your eyes. And now open them.'

I do not know how to describe that moment in words.

What I saw was something similar to a flowing stream which glowed with all the colours of the rainbow, a river broad beyond all measure that flowed from somewhere lost in infinity towards that same infinity. [...] To be more precise, the rainbow-hued stream was everything that I could possibly think of or experience, everything that I could possibly be or not be, and I knew quite certainly that it was not something separate from myself. It was me, and I was it. I had always been it, and nothing else.

'What is it?' I asked.

'Nothing,' replied Chapaev.

'No, not in that sense,' I said. 'What is it called?'

'It has various names,' Chapaev replied. 'I call it the Undefinable River of Absolute Love. Ural for short. Sometimes we become it, and sometimes we assume forms, but in actual fact neither the forms nor we ourselves, nor even de Ural exists." Mantivemos o nome original do rio pela significância do rio Ural na história de Chapaev. A tradução entre colchetes é nossa. 
A primeira informação que podemos destacar nessa descrição é o fato de que Tchapaiev chama o rio de Ural, mesmo nome do rio onde mergulhou em uma fuga do Exército Vermelho de uma ofensiva dos Brancos. O corpo de Tchapaiev nunca foi encontrado.

Em contrapartida, a referência do mundo habitual - seguindo os termos de Piotr - é completamente sobreposto pela discussão metafísica contida no rio. Uma corrente colorida, que na verdade é parte de Pustota e a qual ele reconhece como si mesmo é uma utilização muito hábil da alegoria das gotas de cera, da tomada de formas que se dá pela nossa mente. O que Tchapaiev fala sobre a transição entre sonhos é, aqui, comparado às formas que assumimos enquanto não conseguimos atingir esse rio.

A figura de uma corrente que flui infinitamente tem a significância de uma personalidade ou identidade eterna, que está além das gotas, que é uma essência do ser. Existir é apenas um dos muitos conceitos que abarcam essa mesma inexistência em que estão contidos. Libertaram-se do mundo - inclusive, que os perseguia -, agora precisam libertar-se das formas que assumiram nessa realidade. O sonho de Piotr desmorona, mas, conforme vimos, de uma destruição, do caos, há a formação de uma nova ordem, uma restauração do mundo.

Pelevin usa essa proposição de Prigogine de maneira primorosa, tendo no subterrâneo o Budismo e um Vazio que cria as realidades. Ao perceber as ilusões que criava para si, nosso herói precisa sair em busca de sua essência, daquilo que existe de fato, o que está além dos mundos que não só nos narrou, mas dos quais foi o fundador. 
Por isso, ao ver Tchapaiev e Anna realizarem a única opção no "lugar nenhum" que era o mundo de 1919 - mergulhar no rio -, Pustota se assusta, pois seu isolamento total nesta realidade nunca ocorrera. Em todos os momentos ele era confrontado com o heroísmo e com os dilemas de Tchapaiev, desde que o acompanhamos na fuga da Cheka. Agora, ao ver-se sozinho,

\begin{abstract}
Sem me dar um momento para pensar, apoiei-me em meus pés, corri para a frente e me atirei de cabeça no Ural.

Eu mal senti algo; a corrente estava simplesmente em todo o meu redor, e então não havia mais lados. Eu vi o ponto de onde essa corrente se originava - e imediatamente reconheci como meu verdadeiro lar. Como um floco de neve capturado pelo vento, eu me movi inerentemente em direção a esse ponto. Primeiro, meu movimento era leve e fácil, então algo estranho aconteceu; eu comecei a sentir uma fricção incompreensível puxando minhas panturrilhas e meus cotovelos, e meu movimento ficou mais lento. $\mathrm{E}$ tão logo ele começou a ficar lento, o brilho ao meu redor começou a desvanecer, e naquele momento em que fiquei completamente imóvel, a luz mudou para um feixe lúgubre, que eu percebi vir de uma lâmpada acesa logo abaixo do teto.

Meus braços e minhas pernas estavam atados firmemente à cadeira, e minha cabeça repousava sobre um travesseiro coberto com um pano.

Os lábios grossos de Timur Timurovitch se materializaram à frente da luz escurecida, aproximou-se da minha testa e deu um longo e úmido beijo nela.

"Catarse total," ele disse. "Parabéns." (PELEVIN: 1999, p. 310) ${ }^{109}$
\end{abstract}

Isolado de Anna, Tchapaiev e do mundo de 1919, a catarse se dá pela

liberdade da ilusão e um retorno à realidade autêntica em que se encontra a

essência de Piotr. Apesar disso, antes de se ver livre do hospício, ainda há a

necessidade de um teste proposto por Timurovitch para que Pustota possa voltar à

Moscou de 1991.

109 No original em inglês: "Without giving myself even a moment's pause for thought, I leapt to my feet, ran forwards and threw myself headlong into the Ural.

I hardly felt anything at all; the stream was simply on every side of me now, and so there were no more sides. I saw to spot from which this stream originated - and immediately recognized it as my true home. Like a snowflake caught up by the wind, I was born along towards that spot. At first my movement was easy and weightless, and then something strange happened; I began to feel some incomprehensible friction tugging at my calves and my elbows, and my movement slowed. And no sooner did it begin to slow than the radiance surrounding me began to fade, and at the very moment when I came to a complete standstill, the light changed to a murky gloom, which I realized came from an electric bulb burning just under the ceiling.

My arms and legs were belted tight to the chair, and my head was resting on a pillow covered in oilcloth.

Timur Timurovich's thick lips materialized out of the dim half-light, approached my forehead and planted a long, wet kiss on it.

'Total catharsis,' he said. 'Congratulations.'” 
É quando ele recebe esta "simples formalidade" (p. 318) que nos são narradas algumas questões: após uma, ele começa a ter memórias de uma noite de outubro em 1917; em outra, uma das opções de resposta à pergunta "quem criou o Universo?" é Kotovsky (p. 319). A catarse total à qual Timurovitch se refere começa a dar sinais de ser apenas mais um salto entre realidades pelos quais fomos carregados pelo protagonista durante todo o romance.

Ao questionar a utilidade do teste, Piotr confronta Timurovitch, que resolve não dar importância à prova e rasga o questionário. Com isso, a liberdade se aproxima cada vez mais de Pustota: "as portas da liberdade abriram de uma maneira tão banal e vulgar que eu, na verdade, me senti meio desapontado (p. 321) $)^{110}$. Some a épica da Guerra Civil, o conflito que estimulava Piotr; ressurge a existência ordinária que o levou a criar as realidades ilusórias.

Chegando à estação de trem, enfim fora do hospício, Piotr vê o letreiro com o nome "Lozovaya Junction", e novamente retomamos a batalha na qual ele se tornou herói do Exército Vermelho, junto com Tchapaiev. Tudo que nos é narrado aparenta a ideia de retorno - inclusive à narrativa de 1919, que se iniciou na Avenida Tverstnoy, no encontro com Vorblei.

Ali, "comenta que 'o Pushkin de bronze havia desaparecido, mas a fenda aberta que aparecera onde ele costumava ficar parecia, de alguma maneira, o melhor dos monumentos possíveis" (BRINTLINGER: 2004, p. 56) ${ }^{111}$

Ele retorna ao cabaré literário, onde esteve "ultimamente", e por isso o segurança libera sua entrada. Ali dentro, temos novamente o álcool e as drogas

110 No original em inglês: "The doors of freedom swung open in such a banal, everyday fashion that I actually felt slightly disappointed."

111 No original em inglês: "[...] comments that 'the bronze Pushkin had disappeared, but the gaping void that had appeared where he used to stand somehow seemed like the best of all possible monuments." 
("dissolva o ecstasy na vodca que funcionará", p. 330) como suportes à tolerância à realidade. Então, ele começa a trabalhar - como poeta, da mesma maneira que em 1919, quando usava suas palavras enquanto comissário de Tchapaiev.

Seu novo poema, inclusive, é lido para o público, como ocorre na confusão da qual precisa escapar quando atira no lustre em sua primeira visita ao cabaré. Desta vez, faz o mesmo, mas surgem tiros no escuro, e ele, em sua tentativa de fuga, vê que foi seguido por homens armados. Ao abrir a porta, enfim, não há surpresa para Pustota, mas para o leitor, apesar dos indícios: o carro blindado de Tchapaiev estava estacionado (p. 334)

Entrando no veículo, ele vê Tchapaiev tal qual se lembrava do comandante, exceto por um detalhe: "a mão estava com um curativo, e eu podia adivinhar facilmente que havia um espaço vazio debaixo da gaze, onde o dedinho deve ter estado" (p. 334) $)^{112}$. A volta do comandante poderia ser considerada uma recaída, mas também devemos levar em consideração a aceitação da realidade.

Pelevin provoca o leitor com uma transição repetitiva entre realidades, uma confusão de mundos que não são definitivos. A catarse de Piotr passa por esses caminhos, tal qual o mergulho no Ural nos mostrou - um movimento inato do protagonista em direção ao seu verdadeiro lar. O ponto que Piotr Pustota almeja é sua essência, e, por fim, podemos depreender que é o terceiro golpe de Tchapaiev: o "quem". A criação do mundo, apesar de a opção no teste ter sido Kotovsky, nós reconhecemos como obra de nosso protagonista, pois também se utiliza da primeira pessoa para narrar o que lemos.

112 No original em inglês: "The hand was bandaged, and I could easily guess that there was empty space under the gauze where the little finger should have been." 
Enfim estão consolidados os três golpes do comandante: o "onde" é o "lugar nenhum"; o "quando" é uma brecha entre os mundos assumidos como realidade; e o "quem" é o herói criador Pustota, o Vazio que é essência de toda realidade possível. Até por causa dessa realização final, Tchapaiev está sem o dedinho, tornando-se o novo Buda que apontou ao nosso protagonista a sua essência. $O$ sumiço com o mergulho no Ural é a possibilidade de retorno à verdade cobiçada.

O romance termina, até de maneira evidente, no carro blindado, com Piotr Pustota sendo levado por Tchapaiev rumo à Mongólia Interior, saindo da Moscou de 1991 em direção à liberdade e ao seu trono superior. O esvaziamento da cidade de 1919 inclui uma sensação de vazio da própria realidade, e isso colabora para a retomada do mundo de Tchapaiev para a narrativa. 


\section{CONCLUSÕES}

Nossa busca por mostrar a complexidade de $A$ metralhadora de argila se fez introduzindo um panorama histórico, corroborado em sonhos diferentes do romance, mas complementado por uma metafísica filosófica que parece apreciada por Pelevin. Com isso, não só comprovamos o valor do autor para uma discussão da nova configuração social e cultural da Rússia - além do comercial, que já foi atingido, por ser um dos autores mais vendidos no país.

Conforme vimos, dois capítulos são absolutamente explícitos em suas referências: Maria tem uma relação direta com o Ocidente, o casamento com Schwarzenegger durante as gravações de um filme hollywoodiano com os "novos russos"; Serdiuk mostra seu apreço pelo Japão como país a ser seguido culturalmente, depois conseguindo um emprego em uma corporação japonesa em Moscou e até praticando o seppuku, completando o ciclo de um verdadeiro samurai. A transformação ocorre na metafísica de Volodin, promovendo uma discussão que vai além das duas vertentes geograficamente delimitadas, e em contrapartida propondo uma libertação mental.

Em todas as personagens há formas de fuga da realidade, seja o sexo de Maria, o álcool de Serdiuk ou os cogumelos de Volodin; da mesma maneira, Piotr faz sexo com Anna (p. 285-288), bebe "moonshine" com Tchapaiev e busca ecstasy em seu retorno a Moscou em 1991. Propusemos que Piotr é a síntese da cisão, e aqui pudemos rever como ele possui todos os ingredientes que significavam uma alteração do mundo de cada um dos seus companheiros de hospício. 
É sugestivo que um herói esquizofrênico, Vazio, contenha em si os diversos mundos que acompanhamos na narrativa, mas isso também é elucidado por Tchapaiev quando estão à beira do Ural: toda forma é vazio. Justamente por isso a escolha de Pelevin foi a narração em primeira pessoa, pois toda possibilidade de existência dentro da fiç̧ão que o autor nos apresenta vem do Vazio, vem de Piotr Pustota.

Os elementos de fuga da realidade (sexo, álcool, drogas) não são os únicos que podemos reconhecer na formação do protagonista, pois somos conduzidos com um plano de fundo Budista em uma Rússia que se abria ao capitalismo ocidental. Para se libertar totalmente, a destruição de todas as realidades significa atingir sua essência, que está no esvaziamento desses mundos infectados com valores apresentados pelas outras personagens.

A catarse de Piotr só será possível quando 1919 e 1991 sumirem, inclusive porque o aspecto repressivo de ambas as realidades é evidente: a sensação de liberdade da Guerra Civil é pelo caráter ilusório, só evidenciado pelo uso de uma metralhadora. Do outro lado, no hospício, Timur Timurovitch Kanashnikov carrega com sua terapia a outra metralhadora que reprime o protagonista. A Mongólia Interior, que está além do espaço e do tempo, implica em uma ascensão espiritual transcendendo nossa materialidade.

Pelevin abrange mais do que uma análise crítica da Rússia, que experimenta um novo modelo social e cultural após a queda dos soviéticos. Toda análise que apresentamos sobre a ficção pós-soviética concluiu que a ilusão exposta foi a centelha para a criação de novos mundos alternativos para os autores; propomos, então, que a Rússia reconstruída por Pelevin carrega consigo uma profundidade 
espiritual e metafísica ainda intocadas pelas novas identidades que florescem no país.

Situar tal autor no contexto histórico russo recente implica assumir que ele possui uma voz literária única e estabelecida nas obras publicadas. A dificuldade de traçar o perfil de Pelevin enquanto um autor de massa, cuja obra se torna popular e o autor, paradoxalmente, se isola socialmente, é sobreposta pela presença de algumas figuras recorrentes e importantes em seus livros: a ambição filosófica e uma ironia simultânea a essa mesma ambição e categorizações críticas.

Desta maneira, Pelevin nos apresenta uma escrita agressiva e provocadora, com a qual, ao mesmo tempo em que sugere discussões profundas sobre natureza humana, questões existenciais e releitura da realidade, também mostra a fragilidade desses objetos enquanto verdades absolutas. Sua própria figura como escritor compreende tanto um resultado comercial de sucesso quanto um afastamento em relação ao público. A ironia de Pelevin acaba por extrapolar seus escritos, abrangendo também seu perfil intencionalmente misterioso.

Por outro lado, sua presença na conjuntura da literatura russa historicamente estabelecida tem profunda significância, pois representa um perfil de desconstrução das realidades propostas - e impostas - após a queda dos soviéticos. Essa espécie de niilismo, muito representado no protagonista que estudamos, que não é curável por ser esquizofrênico, marca uma posição extremamente forte em relação à visão de futuro da Rússia no mundo que se estabelecia após um século de conflito ideológico e político.

Se reconhecemos a importância histórica de Dostoievski ao desenvolver o "homem do subsolo", figura que representaria a partir dali a emergência de uma 
nova "consciência russa", Pelevin promove uma discussão mais pessimista quanto a qualquer delimitação exata de identidade russa após o final do século $X X$. O romance aqui estudado, por exemplo, é a expressão por excelência de um trânsito entre realidades destrutíveis e questionáveis que assumimos como verdade, mas que, para o autor, se desfazem dentro de nós - ou de Piotr.

Trafegar por essas realidades nos distancia de um cerne de identidade, como a aceitação da gota em vez da cera, quando aparece o Barão Jungern. A proposta que vimos é a percepção de diversas possibilidades de real, num mundo composto por diversas fronteiras - bem como a dualidade proposta por Lotman, a complexidade dos embates históricos sempre permeados por semelhanças autoritárias, ou até as nuances de transição entre sonho e hospício no romance. Esse mesmo cerne, por sua vez, só é possível quando esvaziamos todas as possibilidades que, antes, acreditávamos serem sólidas e inquestionáveis.

Ademais, nossa leitura de $A$ metralhadora de argila pretende expandir os alvos das metralhadoras de Pelevin: devemos estar, assim como a Rússia dentro de Piotr Pustota, abertos à possibilidade de desconstrução das realidades que acreditamos ser autênticas. Valores solidificados podem ser apenas formas que assumimos temporariamente, consolidando uma ilusão que nos afasta de nossa essência. O caminho que devemos traçar, nossa "narrativa de formação", deve ser em direção à liberdade eterna, que só será possível se aceitarmos o vazio dentro de nós como a forma mais pura de real - e, assim, poderemos atingir nossa própria Mongólia Interior. 


\section{REFERÊNCIAS}

BRINTLINGER, Angela. The Hero in the Madhouse: The Post-Soviet Novel Confronts the Soviet Past. Slavic Review, Urbana-IL, Vol. 63, No. 1, 2004, p. 43-65.

COWLEY, Jason. 23 de janeiro de 2000. Gogol a Go-Go. Disponível em http://www.nytimes.com/2000/01/23/magazine/gogol-a-go-go.html. Acesso em $10 \mathrm{de}$ novembro de 2016.

DALTON-BROWN, Sally. Ludic Nonchalance or Ludicrous Despair? Viktor Pelevin and Russian Postmodernist Prose. The Slavonic and East European Review, Londres, Vol. 75, No. 2, 1997, p. 216-233.

DARMAPADA: A doutrina budista em versos (trad. Fernando Cacciatore de Garcia). $1^{a}$ edição. Porto Alegre: L\&PM Editores, 2010.

EPSTEIN, Mikhail. "The Dialetics of Hyper: From Modernism to Postmodernism" in: EPSTEIN, M.; GENIS, A.; VLADIV-GLOVER, S. Russian Postmodernism: New Perspectives on Post-Soviet Culture. 1ª edição. New York: Bergahn Books, 1999, p. 3-30.

GENIS, Alexander. Borders and metamorphoses: Viktor Pelevin in the context of post-Soviet literature. In: EPSTEIN, M.; GENIS, A.; VLADIV-GLOVER, S. Russian Postmodernism: New Perspectives on Post-Soviet Culture. $1^{\text {a }}$ edição. New York: Berghahn Books, 1999, p. 212-224.

GROYS, Boris. "Educando as massas: a arte do Realismo Socialista" in: GROYS, Boris. Arte, Poder (trad. Virgínia Starling). $1^{\text {a }}$ edição. Belo Horizonte: Editora UFMG, 2015, p. 177-186.

JAHN, Hubertus. “Us': Russians on Russianness” in: FRANKLIN, S.; WIDDIS, E. National Identity in Russian Culture: An Introduction. $1^{\text {a }}$ edição. Cambridge: Cambridge University Press, 2004, p. 53-73.

KARAMZIN, Nikolai. "Do amor à pátria e do orgulho nacional (1802)" (trad. Cecília Rosas) in: Antologia do pensamento crítico russo (1802-1901) (org. Bruno Barretto Gomide). $2^{a}$ edição. São Paulo: Editora 34, 2017, p. 27-35.

LIPOVETSKY, Mark. Russian Literary Postmodernism in the 1990s. The Slavonic and East European Review, Londres, Vol. 79, No. 1, 2001, p. 31-50.

LOTMAN, Jurij. "The Role of Dual Models in the Dynamics of Russian Culture (Up to the End of the Eighteenth Century)" (trad. N. F. C. Owen) in: LOTMAN, J. M.; USPENSKY, B. A. The Semiotics of Russian Culture. $1^{\text {a }}$ edição. Ann Arbor: Michigan Slavic Publications, 1984, p. 3-35.

MACHADO, Roberto. "A Loucura" in: MACHADO, R. Foucault, a filosofia e a literatura. $1^{a}$ edição. Rio de Janeiro: Zahar, 2000, p. 15-52. 
MARQUES, P. Polifonia e emoções: Um estudo sobre a construção da subjetividade em Crime e castigo de Dostoiévski. 2010. 324f. Dissertação de Mestrado. Universidade de São Paulo, São Paulo, 2010.

MCCAUSLAND, G. "Viktor Olegovich Pelevin" in: Dictionary of Literary Biography, Volume 285: Russian Writers Since 1980. Thomson Gale, 2004.

MELETÍNSKI, Eleazar. Os arquétipos literários (trad. Aurora Bernardini, Homero de Andrade e Arlete Cavaliere). $2^{\mathrm{a}}$ edição. Cotia: Ateliê Editorial, 2015.

MEYER, Luciano Augusto. "De Chapaev ao vazio: a Revolução Russa e seus efeitos na literatura pós-soviética" in: História e Cultura, Franca, v.6, n.1, 2017, p. 195-212.

PELEVIN, Victor. The Clay Machine-gun (trad. Andrew Bromfield). $1^{\text {a }}$ edição. Londres: Faber and Faber, 1999.

TCHAADÁIEV, Piotr. "Primeira carta filosófica (1836)" (trad. Cecília Rosas) in: Antologia do pensamento crítico russo (1802-1901) (org. Bruno Barretto Gomide). $2^{\mathrm{a}}$ edição. São Paulo: Editora 34, 2017, p. 67-85.

TOLZ, Vera. "The West" in: LEATHERBARROW, W.; OFFORD, D. A History of Russian Thought. $1^{\text {a }}$ edição. Cambridge: Cambridge University Press, 2010, p. 197216.

VAN DER OYE, David. "The East" in: LEATHERBARROW, W.; OFFORD, D. A History of Russian Thought. $1^{\text {a }}$ edição. Cambridge: Cambridge University Press, 2010, p. 217-240. 